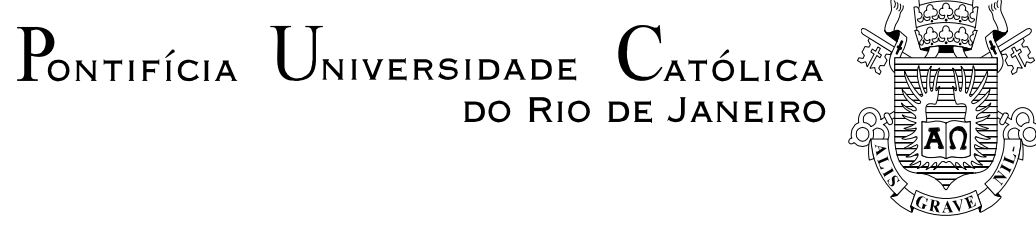

Elisa Rodrigues Maia

Jenny Holzer: entre a palavra e a imagem

Dissertação de Mestrado

Dissertação de Mestrado apresentada como requisito parcial para obtenção do grau de Mestre em Letras do Departamento de Letras da PUC-Rio como parte dos requisitos parciais para obtenção do título de Mestre em Letras.

Orientador: Prof. Karl Erik Schollhammer

Rio de Janeiro

Setembro de 2012 


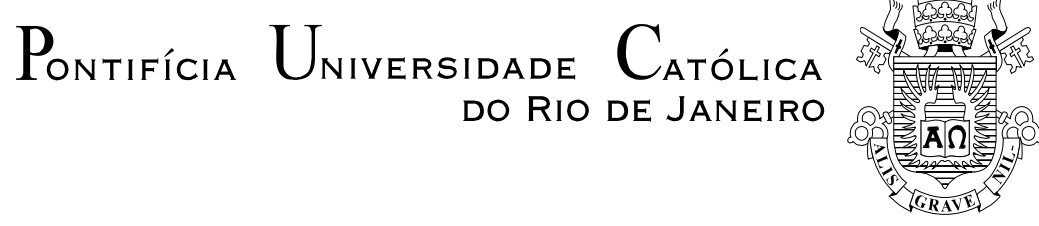

Elisa Rodrigues Maia

\title{
Jenny Holzer: entre a palavra e a imagem
}

Dissertação apresentada como requisito parcial para obtenção do grau de Mestre pelo programa de PósGraduação em Letras do Departamento de Letras do Centro de Teologia e Ciências Humanas da PUC-Rio. Aprovada pela Comissão Examinadora abaixo assinada.

\author{
Prof $^{\circ}$ Karl Erik Schollhammer \\ Orientador \\ Departamento de Letras - PUC-Rio
}

Prof $^{\circ}$ Frederico Oliveira Coelho Departamento de Letras - PUC-Rio

Prof $^{\circ}$ Antonio Pacca Fatorelli ECO/UFRJ

Profa. Denise Berruezo Portinari Coordenadora Setorial do Centro de Teologia e Ciências Humanas - PUC-Rio

Rio de Janeiro, 05 de setembro de 2012. 
Todos os direitos reservados. É proibida a reprodução total ou parcial do trabalho sem autorização da universidade, da autora e do orientador.

\section{Elisa Rodrigues Maia}

Professora de Literatura, graduou-se em Direito e em Letras pela Pontifícia Universidade Católica do Rio de Janeiro e cursou o mestrado em Literatura, Cultura e Contemporaneidade nesta mesma instituição.

Ficha Catalográfica

Maia, Elisa Rodrigues

Jenny Holzer: entre a palavra e a imagem / Elisa Rodrigues Maia ; orientador: Karl Erik Schollhammer. 2012.

94 f. ; $30 \mathrm{~cm}$

Dissertação (mestrado) - Pontifícia Universidade Católica do Rio de Janeiro, Departamento de Letras, 2012.

Inclui bibliografia

1. Letras - Teses. 2. Jenny Holzer. 3. Palavra e imagem. 4. Hibridismo. 5. Representação. 6. Cultura visual. I. Schollhammer, Karl Erik. II. Pontifícia Universidade Católica do Rio de Janeiro. Departamento de Letras. III. Título.

CDD: 800 


\section{Agradecimentos}

Ao meu orientador Professor Karl Erik Schollhammer, pelo compromisso acadêmico e pela generosidade.

Ao CNPq e à PUC-Rio, pelos auxílios concedidos.

Aos membros da banca examinadora, Antonio Fatorelli e Frederico Coelho.

À minha família, por tudo. 


\section{Resumo}

Maia, Elisa Rodrigues; Schollhammer, Karl Erik (Orientador). Jenny Holzer: entre a palavra e a imagem. Rio de Janeiro, 2012. 94p. Dissertação de Mestrado - Departamento de Letras, Pontifícia Universidade Católica do Rio de Janeiro.

O objetivo desta dissertação é pensar a relação que se estabelece entre a palavra escrita e a imagem no trabalho da artista visual norte-americana Jenny Holzer. Desde que Holzer espalhou por Manhattan, em 1977, pôsteres anônimos contendo frases polêmicas (truísmos), seu trabalho tornou-se objeto de uma abordagem que tende privilegiar o conteúdo dos escritos em detrimento de sua forma. Esta pesquisa parte do pressuposto de que, embora o texto seja o elemento predominante na trajetória da artista, a forma cuidadosa como ela situa as palavras no espaço, costurando o visual ao discursivo, torna a experiência do espectador diferente da leitura. Na sua obra, as palavras investem-se de materialidade, cor, luz, ritmo e movimento, impondo-se tanto por sua presença quanto por seu conteúdo provocador. Esta estratégia coloca em evidência os intervalos entre palavra e imagem, conteúdo e forma, entendimento e sensibilidade, problematizando a legitimidade destes dualismos e apontando para a produção efeitos estéticos complexos que extrapolam a dimensão dos significados do texto.

\section{Palavras-chave}

Jenny Holzer; palavra e imagem, hibridismo, representação, cultura visual. 


\section{Abstract}

Maia, Elisa Rodrigues; Schollhammer, Karl Erik (Advisor). Jenny Holzer: between word and image. Rio de Janeiro, 2012. 94p. Dissertação de Mestrado - Departamento de Letras, Pontifícia Universidade Católica do Rio de Janeiro.

The objective of this dissertation is to investigate the relationship between word and image in Jenny Holzer's work. Since she has first shown her controversial Truisms on anonymous street posters pasted throughout Manhattan, in 1977, critics have been privileging the content of her writings over its form. The present essay assumes that, although written language plays a central role in her work, the careful way she situates her texts in space, intertwining the textual and the visual, makes for an experience different from reading. The words are invested of materiality, color, light, rhythm and movement, outstanding both for their own presence and for their provocative content. This strategy highlights the gaps between word and image, content and form, knowledge and sensibility, questioning the legitimacy of these dualisms and pointing toward complex aesthetic effects that go beyond the meanings of the text.

\section{Keywords}

Jenny Holzer, word and image, hybridism, representation, visual culture. 


\section{Sumário}

$\begin{array}{lr}\text { Introdução } & 8\end{array}$

1. Palavra e imagem: fronteiras instáveis $\quad 11$

1.1. A palavra e a imagem 11

1.2. A demarcação de fronteiras $\quad 17$

1.3. A pureza dos meios como um "mito modernista” 21

1.4. Poesia Concreta: "tensão de palavras-coisas no espaço-tempo” 25

2. A performance da palavra escrita 31

2.1 Truimos 31

2.2 Desmembrando forma e conteúdo 34

2.3 Complexos imagético-textuais 39

2.4 "Big Brother Media” 42

2.5 Desacelerar $\quad 47$

2.6 Frases lidas “pelos olhos e pelo corpo inteiro” 50

3. Lustmord - Os limites da representação $\quad 54$

3.1 Suddeutsche Zeitung $\quad 54$

3.2 A representação do estupro 62

3.3 Imagens difíceis de se olhar $\quad 65$

3.4 A representação sob a ótica da legitimidade $\quad 74$

3.5 Dos regimes da arte $\quad 84$

$\begin{array}{lr}\text { Referências bibliográficas } & 91\end{array}$ 


\section{Introdução}

Nas últimas décadas, uma série de fatores tem colaborado para um crescente entrelaçamento entre palavra e imagem. O cotidiano contemporâneo é tão inundado de experiências que envolvem formas híbridas (televisão, cinema, revistas, anúncios publicitários), que os próprios limites que separaram esses domínios ameaçam desaparecer. Neste processo de diluição das antigas fronteiras entre os meios de expressão visuais e textuais, as mídias que fazem uso da tecnologia digital se destacam ao abrir caminhos de leitura não lineares, por onde o leitor percorre espacialidades e temporalidades, até então, desconhecidas. Paralelamente, no âmbito da teoria da literatura, uma perspectiva autocrítica parece ganhar terreno desafiando limites e atribuições, desconstruindo e reconstruindo o estatuto dos estudos literários. Um dos desdobramentos desse processo de autorreflexão é a exploração dos contornos e das atividades que constituem a literatura, encontrada nas manifestações que buscam justamente desestabilizar esta noção, mesclando o "literário” com o que, até então, encontrava-se à margem de seus limites. Neste sentido, os conteúdos “puros”, que foram temporariamente resguardados pelos limites rigorosos dos departamentos acadêmicos, contaminam-se favorecendo as perspectivas transdisciplinares. Na esteira destas mudanças, os confrontos entre texto e imagem mostram-se terrenos férteis para a escavação de novos caminhos que parecem deliberadamente percorrer terrenos que por algum tempo mantiveram-se afastados, como a teoria da literatura e a história da arte. No campo da prática, é possível ver uma produção que não está mais preocupada em pertencer a uma determinada categoria, seja a poesia, a música, a pintura, a arquitetura ou o cinema. Consciente da dificuldade (ou talvez mesmo da irrelevância) de se sustentar a pureza dos gêneros ou a especificidade dos meios, essa produção transita livremente tanto por diferentes práticas artísticas, quanto por espaços destinados a atividades tradicionalmente consideradas “não artísticas” (ou talvez “menos artísticas”), como o jornalismo, a propaganda, a moda e o design. Essas travessias constituem uma característica fundamental da obra de Jenny Holzer. Parece haver no seu trabalho algo que sempre escapa aos limites do suporte e que atravessa as fronteiras dos gêneros, contribuindo para o questionamento e a desestabilização 
dessas categorias. Sua obra não apenas lança mão dos mais variados suportes revistas, bonés e camisetas, pele humana, bancos de granito, monumentos arquitetônicos - como também, e principalmente, consegue provocar uma hesitação em cada um desses meios, individualmente. Ao inscrever seus textos em bancos de granito e colocá-los em espaços públicos, por exemplo, Holzer transforma a pedra em suporte da escrita e também em escultura, sem que no entanto ela deixe de ser um "banco de praça”, situado ali para acomodar os passantes. Nos trabalhos de Holzer, a atenção dirigida à materialidade e à visualidade da palavra escrita resultam em uma linguagem híbrida, na qual os contornos entre o que é lido e o que é visto desaparecem. Suas instalações operam revezamentos plástico-discursivos, contaminações recíprocas entre o texto e a imagem, transformando a leitura em uma experiência sensual que extrapola a dimensão dos significados do texto.

O objetivo desta dissertação é investigar os efeitos estéticos que na obra de Holzer derivam da fusão entre os sistemas linguístico e visual. Para isso, dividimos a pesquisa em três partes. O primeiro capítulo é dedicado aos conceitos de palavra e imagem. Antes que se aborde a questão do hibridismo na obra de Holzer, este breve desvio se faz necessário, uma vez que a proposta de um estudo das relações e aproximações entre os campos da palavra e da imagem não seria possível sem que antes se tentasse conceber cada um deles individualmente. Concentraremos o foco tanto nos movimentos de construção de "fronteiras teóricas” entre os meios de expressão discursivos e visuais, quanto nos impulsos de cruzamento dessas fronteiras. No segundo capítulo, deixamos as questões teóricas de lado para nos concentrarmos diretamente em alguns momentos da obra de Jenny Holzer. Pretende-se dirigir a atenção para a forma como na sua obra, tanto imagem quanto palavra escrita rasgam e atravessam as fronteiras que lhes foram tradicionalmente impostas, apontando para novas vias de esgarçamento destas linguagens e, sobretudo, beneficiando-se da complexidade dos efeitos estéticos derivados desta interação. Neste sentido, buscamos investigar como os seus complexos imagético-textuais se mostram capazes de intervir performaticamente na realidade dos espaços em que são cuidadosamente situados. No último capítulo, elegemos um trabalho específico da artista, intitulado, Lustmord (1993) - no qual a metáfora do corpo inscrito ganha a sua materialização mais contundente - como ocasião para pensar a representação da 
violência. Uma análise de polêmicas recentes em torno dos "limites da representação" parece evidenciar que as (supostamente) antigas iniciativas de separar os domínios da palavra e da imagem, típicas do Modernismo do século XX, ainda encontram espaço e força na cultura contemporânea em abordagens que buscam estabelecer regras de adequação entre forma e conteúdo. 
1

\section{Palavra e imagem: fronteiras instáveis}

\section{1}

\section{A Palavra e a imagem}

Tradicionalmente, palavra e imagem têm sido compreendidas como duas formas de expressão, representação e cognição distintas, ainda que profundamente intrincadas. Diz-se da palavra que é um signo linguístico arbitrário e convencional, o que implica afirmar que não há uma relação de motivação relevante entre uma palavra e o seu significado. Neste sentido, é conhecida a controvérsia grega acerca da origem dos nomes, na qual a visão naturalista, que defendia que os nomes "eram por natureza", ou seja, não dependiam de convenção, é contraposta à visão convencionalista, que aduzia que os nomes eram produtos de “acordos”. No célebre diálogo platônico, Crátilo, as duas teses rivais são apresentadas:

\footnotetext{
"Hermógenes - Sócrates, o nosso Crátilo sustenta que cada coisa tem por natureza um nome apropriado e que não se trata de denominação que alguns homens convencionaram dar-lhes [...] mas que, por natureza, têm sentido certo $[\ldots]$ "..

"Hermógenes - Por minha parte, Sócrates, já conversei várias vezes a esse respeito tanto com ele quanto com outras pessoas, sem que chegasse a convencer-me de que a justeza dos nomes não se baseia em outra coisa que não seja convenção e acordo.” (Platão, Crátilo, 383a-384e. grifo meu)
}

Aristóteles adere à tese convencionalista, apresentando-a já fora de qualquer polêmica, “é segundo convenção, pois nenhum dos nomes é por natureza [...]” (Aristóteles, 16a). A prova de que os vínculos que unem significante e significado são convencionais, e não naturais, seria a existência de incontáveis línguas e dialetos nos quais a mesma idéia é designada por palavras distintas que, muitas vezes, não guardam qualquer semelhança entre si. O linguista Ferdinand de Saussure observa a situação em que o significante é relativamente, e não absolutamente, arbitrário, como no caso das onomatopeias, enfatizando que, ainda assim, reside um grau de arbitrariedade, haja vista que as onomatopeias não são as 
mesmas em países de línguas diferentes - “...sua escolha é já, em certa medida, arbitrária, pois que não passam de imitação aproximativa e já meio convencional de certos ruídos” (Saussure, 2006, p. 83). Em contrapartida, ao contrário do que ocorreria com a representação linguística, a representação visual seria aquela que lançaria mão de signos naturais e universais. Desta forma, o desenho de um barco, por exemplo, seria motivado pela ideia visual que se costuma fazer de "barco" e, entre os dois, significante e significado, haveria um vínculo natural e não convencional. Assim, em tese, o desenho do barco, ao contrário do que ocorreria com a palavra "barco", deveria ser compreendido em qualquer lugar, independente da língua nativa, e em qualquer período.

Em relação a sua recepção, diz-se das palavras que se apresentam de forma sucessiva, pertencendo, assim, à ordem do tempo, enquanto as imagens se apresentariam de forma simultânea, pertencendo, desta forma, à ordem atemporal do espaço. Quando faladas, as palavras são de fato pronunciadas consecutivamente e quando escritas, embora habitem de forma simultânea o espaço da página, não podem, em regra, ser lidas senão uma após a outra. Em contrapartida, as imagens não costumam trazer prescritas em si uma forma específica de apreensão (como ocorre com o texto, onde as palavras são lidas da esquerda para a direita, e as frases, de cima para baixo). Mesmo porque, teoricamente, uma imagem é apreendida de uma só vez, seus elementos são vistos simultânea e não sucessivamente. Afirma-se que a palavra significa por diferença, remetendo, portanto, a uma realidade ausente, enquanto a imagem significaria por semelhança, oferecendo a sua presença como substituta da realidade ausente a que ela se assemelha. Sobre o assunto, Michel Foucault afirma que "faz-se ver pela semelhança, fala-se através da diferença. De modo que os dois sistemas não podem se cruzar ou fundir" (Foucault, 2008, p. 36). No que diz respeito ao impacto sensível exercido sobre o observador, a representação visual assume uma posição de superioridade em relação à representação literal. A imagem, em regra, é absorvida mais facilmente pelo público do que a palavra, uma vez que a sua presença tem a capacidade de engendrar uma percepção quase automática, liberta da mediação dos esforços interpretativos empregados na leitura do signo linguístico. Sobre o assunto, Karl Erik Schollhammer: 
"Não há mais dúvida sobre a superioridade contemporânea da representação visual em termos de eficiência de divulgação e de impacto sensível sobre o público. O sucesso dos meios de comunicação deve-se em parte à facilidade de percepção e ao automatismo com que o público absorve a imagem viva." (Schollhammer, 2007, p.9)

As definições de palavra e imagem, em que pese seu enorme valor didático, não deixam de apresentar as brechas características das categorias teóricas que, em prol da generalização necessária à definição de um objeto, acabam por apagar traços particulares. W. J. T. Mitchell, da Universidade de Chicago, sublinha a necessidade de se atentar para o fato de que chamamos de “imagem” uma infinidade de coisas que não necessariamente guardam semelhanças entre si. Uma pintura é uma imagem, assim como uma memória, um mapa, um sonho, uma escultura e um gráfico também são. Encontramos imagens em espelhos, quadros, livros, mas também em metáforas, poemas e descrições. E neste sentido, convém lembrar a frase de Marcel Proust, que em carta a Jean Cocteau, escreveu a respeito de Em Busca do Tempo Perdido - “Meu livro é uma pintura” (Karpeles, 2008, p. 10). Diante da dificuldade de se chegar a uma definição universal do termo e esquivando-se dos problemas enfrentados pelas definições que seguem uma via essencialista, Mitchell propõe uma abordagem descritiva (e não prescritiva) do que seriam as imagens, estabelecendo uma possível genealogia onde elas são organizadas com base nas fronteiras que separam diferentes discursos institucionais. Desta forma, cada um dos grupos definidos por Mitchell designaria um tipo de imagem central ao discurso de uma determinada disciplina intelectual (Mitchell, 1986, p. 9-10). A sua proposta pode ser esquematizada da seguinte forma: 


\begin{tabular}{|l|l|l|l|l|}
\hline \multicolumn{5}{|c|}{ IMAGEM } \\
\hline Gráfica & \multicolumn{1}{|c|}{ Ótica } & Perceptiva & Mental & Verbal \\
\hline $\begin{array}{l}\text { figuras } \\
\text { estátuas } \\
\text { desenhos }\end{array}$ & $\begin{array}{l}\text { espelhos } \\
\text { projeções }\end{array}$ & $\begin{array}{l}\text { construídas } \\
\text { pelos sentidos } \\
\text { aparências }\end{array}$ & $\begin{array}{l}\text { sonhos } \\
\text { memórias } \\
\text { ideias }\end{array}$ & $\begin{array}{l}\text { Metáforas } \\
\text { Descrições }\end{array}$ \\
\hline $\begin{array}{l}\text { História da } \\
\text { Arte }\end{array}$ & Física & $\begin{array}{l}\text { Neurologia } \\
\text { Psicologia } \\
\text { História da Arte } \\
\text { Estudos da ótica } \\
\text { Filosofia } \\
\text { Crítica Literária }\end{array}$ & $\begin{array}{l}\text { Psicologia } \\
\text { Epistemologia }\end{array}$ & $\begin{array}{l}\text { Crítica } \\
\text { Literária }\end{array}$ \\
& & & & \\
\hline
\end{tabular}

Mitchell critica as concepções materialistas segundo as quais apenas as imagens gráficas e óticas seriam "imagens próprias”, ao passo que as demais (verbais, perceptivas e mentais) só poderiam ser consideradas “imagens” em um sentido metafórico. Seu argumento é de que as imagens gráficas, assim como acontece com as imagens mentais, são apreendidas de formas distintas por diferentes espectadores e, portanto, podem ser consideradas tão “ilegítimas" quanto as demais. Ao contrário do que sustentam as teorias tradicionais, tais imagens não são estáticas ou permanentes e, por mais literais que pareçam, envolvem sempre distorções ideológicas em relação ao “real” que representam. A invenção no século XV da perspectiva central, o método capaz de traduzir para a superfície plana e bidimensional o espaço e os objetos tridimensionais, é apontada por ele como a revolução responsável por promover a concepção da imagem ("forma artificial”) como semelhança visual. Impulsionada pela crescente valorização da razão, da ciência e da objetividade, a perspectiva central tornou-se o método de representação dominante, aquele identificado com as noções de “verdade” e "realidade”. Entre os seus muitos méritos, estaria a sua capacidade de camuflar a própria artificialidade, fazendo-se passar pelo método ideal de representação do mundo empírico como o vemos, ou das coisas como são.

Contra as ilusões realistas da imagem como representação natural, tornouse famosa a teoria defendida por Ernst H. Gombrich em Arte e Ilusão (1959). Neste trabalho, o historiador da arte problematizou o pensamento que concebia a diferença entre signos lingüísticos e signos pictóricos a partir das oposições 
convencional/natural, ou arbitrário/motivado. O autor defende o argumento de que não há uma forma natural ou neutra de ver o mundo que possa ser representada por um método igualmente "neutro" (como pretendia ser a perspectiva central), uma vez que, nem mesmo a visão seria um processo puramente ótico, mas, antes, uma experiência que envolveria uma linguagem adquirida, responsável por coordenar as impressões óticas de modo a construir um campo visual estável e coerente. Em outras palavras, não poderia haver uma visão desinteressada ou imparcial, uma vez que a visão seria um produto da experiência e da cultura do observador. Sabe-se que Gombrich, algumas décadas mais tarde, veio a relativizar a sua teoria em defesa da base naturalista e do papel da similaridade presentes na representação pictórica, mas, ainda assim, o debate em torno do quanto, em uma representação, é natural e do quanto é convencional continua em aberto. Ao lado das teorias que questionaram a naturalidade do signo visual, começam a ganhar importância estudos que, em sentido oposto, questionam a arbitrariedade do signo linguístico. Partindo das aproximações entre os campos da literatura e da filosofia, estes estudos sugerem que a literatura seria o lugar privilegiado onde poderia ser encontrado um resquício da tese naturalista na justificativa da escolha de nomes, sobretudo de nomes próprios. Neste sentido, são citados exemplos como a escolha do nome "Guermant", do romance Em Busca do Tempo Perdido de Marcel Proust ou do nome "Mag” no romance Molloy, de Samuel Beckett. Sobre a escolha do nome Guermant, Proust afirma que não teria sido arbitrária, mas sim motivada pelo fonema "mant”, cuja sonoridade evocaria analogias com a aristocracia francesa, por "se arrastar como a cauda de um pavão”. No exemplo de Beckett, a escolha do nome "Mag”, assim como a justificativa apresentada pelo narrador, também contribui para subverter os pressupostos básicos acerca do nome próprio, isto é, de que seria arbitrário e esvaziado de sentido, e confere-lhe, ainda, um papel performativo:

"Quando devia dar-lhe um nome, chamava-a de Mag. E se a chamava de Mag era porque, segundo eu próprio, sem saber explicar por que, a letra $G$ abolia a sílaba ma e por assim dizer cuspia em cima, como nenhuma outra letra faria melhor. E ao mesmo tempo eu satisfazia uma necessidade profunda e com certeza inconfessável de ter uma ma, isto é, uma mamãe, e de proclamar, em voz alta. Porque antes de dizer mag a gente diz ma forçosamente”. (Molloy. p. 15). 
Quanto à questão temporal, o pressuposto de que as palavras se apresentam de forma sucessiva, que se desenrolam no tempo, é desafiado por construções como a dos caligramas, ou dos poemas concretos. Tais usos da linguagem escrita demonstram que os signos da poesia podem ser organizados espacialmente e, desta forma, exigir do leitor que os apreenda simultaneamente, como fenômenos visuais. Além disso, enfatizam que a palavra escrita, assim como a imagem, é também dotada de forma e não deixa de oferecer ao leitor, além do referente linguístico ausente, a sua presença material. No mesmo sentido, sabe-se que os signos pictóricos podem ser organizados sequencialmente, como mostram as pinturas da Idade Média que exigem do espectador um processo temporal de apreensão. Por fim, em que pese a sua presença e seu aparente imediatismo, uma imagem não deixa de se constituir não apenas pelo que é mostrado, mas também pelo que se torna dizível a partir dela e por suas lacunas, criadoras de visualidades que se estendem para além dos limites da visão.

A dificuldade de caracterizar isoladamente cada um dos campos é reforçada, portanto, pela maneira como ambos funcionam no imaginário individual. Sabe-se que a palavra é responsável pelo despertar de uma imagem mental, que pode ser uma imagem visível, ou seja, exterior ao sujeito e apreendida de seu universo empírico, ou uma imagem não visível, isto é, particular e oriunda do poder imaginativo do leitor de criar visualidades subjetivas. No sentido inverso, a imagem, mesmo quando não se propõe a ser narrativa acaba, em maior ou menor grau, evocando as palavras, sugerindo sentidos ou suscitando explicações que se submetem ao discurso. É possível afirmar, então, que as linhas que separam os domínios da palavra e da imagem são falhas e cheias de vãos por onde os conteúdos transbordam e se comunicam. Contudo, essas linhas não chegam a desaparecer e, mais do que isso, de tempos em tempos, parecem ser reforçadas por construções teóricas que se propõem a demarcar limites rigorosos em torno de cada um dos campos. No que diz respeito especificamente à pintura e à literatura, esforços nesse sentido deram origem a célebres tratados teóricos que se estabeleceram, e figuram até os dias de hoje, como importantes referências nas discussões sobre artes visuais e literatura. 


\section{2}

\section{A demarcação de fronteiras}

As diferenças formais entre a palavra e a imagem foram aprofundadas por teorias estéticas que buscaram estabelecer de forma precisa os limites e as capacidades de cada gênero artístico. Neste debate, destaca-se a contribuição do crítico de arte e dramaturgo alemão Gotthold Lessing, um dos teóricos que ajudou a consolidar a separação entre a literatura e a pintura, numa manobra que pode ser relacionada, entre outras coisas, a um movimento mais amplo de retorno a certos ideais neoclássicos, entre os quais se incluía a pureza dos gêneros artísticos. Esta atitude se opõe à tradição das Artes Irmãs defendida por Horácio em sua Arte Poética, através da noção clássica de Ut Pictura Poesis ("a poesia é como a pintura") e por Simônides de Ceos, que teria afirmado ser a pintura uma poesia muda e a poesia uma pintura que fala. Em um ensaio intitulado Laocoonte, escrito em 1766, Lessing atenta para as “influências perniciosas” decorrentes da falta de limites claros entre a poesia e a pintura, cujas consequências seriam a descrição na poesia pictórica e a narrativa na pintura alegórica. No prefácio de seu ensaio, Lessing deixa claro que pelo termo "pintura” ele se refere às artes plásticas em geral, enquanto no termo "poesia” ele inclui outras artes nas quais a “imitação é progressiva”. O dramaturgo defende a teoria de que nem todos os meios artísticos seriam apropriados para representar um determinado tema ou objeto. Para isso, aposta na separação entre o que ele considerou ser uma arte do tempo (a poesia) e uma arte do espaço (a pintura), a partir das especificidades de cada campo e do respeito aos seus respectivos limites representativos. De acordo com este princípio, a pintura teria como objeto os corpos e suas qualidades visíveis, recorrendo a figuras e cores no espaço para representá-los em um único momento, o "mais expressivo”, a partir do qual seria possível inferir o que se passou e o que se seguiria. Não poderia, portanto, com seus signos naturais e coextensivos no espaço, representar objetos sucessivos no tempo, e seria incapaz de expressar sentimentos, ideias universais ou contar histórias, sem que fossem produzidas “alegorias grotescas”. A poesia, com seu poder de sugestão, seria o meio adequado para representar o invisível e incitar o leitor a trabalhar com a sua imaginação. Diferentemente da pintura, seria, assim, capaz de expressar ideias e sentimentos através de ações que se desdobram no tempo, utilizando-se para isso 
“uma única qualidade dos corpos na sua imitação progressiva” (Lessing, 1998, p. 193). Resumindo, a pintura, como arte simultânea, deveria comprimir a sucessão de ações em apenas um momento, o mais fecundo, ao passo que a literatura, como arte progressiva, distenderia a imagem em uma sucessão de ações consecutivas. Neste sentido, a doutrina de Lessing sublinha a incompatibilidade entre a coexistência de corpos no espaço e a sucessão de ações no tempo. Esta noção servirá de fundamento para a oposição descrição/narração, que será explorada tanto no campo da teoria da literatura (por Georg Lukács em seu ensaio Narrar ou Descrever?) quanto no campo da história da arte (por Svetlana Alpers em A Arte de Descrever, 1983). Segundo esta lógica, a precisão na descrição de uma cena parece ser inversamente proporcional à qualidade com que as ações são representadas, na medida em que a descrição atenta da superfície do mundo se faria às custas da suspensão no tempo da sequência narrativa. Lessing não foi o único a abordar a questão. O poeta Samuel Coleridge foi uma das vozes que, durante o Romantismo, considerou que a descrição pictórica deveria ser evitada pela poesia, insistindo que o poeta, ao invés de retratar o universo visual a sua volta, deveria empenhar-se em provocar no leitor uma resposta emocional. Esta atitude pode ser vista em diálogo com as ideias de Edmund Burke, que associava a obscuridade da poesia à origem emocional da noção de sublime, e a clareza descritiva da pintura à noção de belo. Para ambos, o prazer da poesia deveria ser situado na fantasia ou na imaginação e não na descrição do mundo visível.

Cumpre salientar que o impulso de pureza dos gêneros parece sempre ter convivido com um certo entusiasmo pelos benefícios que poderiam resultar da fusão de diferentes meios artísticos, entusiasmo que, em última instância, culminará na noção wagneriana de “obra de arte total”. No ensaio que escreveu sobre Eugène Delacroix, Charles Baudelaire afirma que um dos sintomas característicos de seu momento histórico é que nele "as artes aspiram, senão tomar os lugares umas das outras, ao menos emprestar-se reciprocamente novos poderes”. De acordo com este pensamento, a poesia, por exemplo, não deveria imitar a pintura, mas sim tomar emprestado para si alguns dos traços característicos do meio pictórico. Neste ensaio, Baudelaire presta homenagem ao gênio de Delacroix exaltando a forma como o pintor romântico, utilizando apenas cores e formas, é capaz de expressar não o seu universo visível, mas, justamente, o “invisível”, o “impalpável”, a “alma”. E o faz com a "perfeição de um exímio 
pintor”, com a "exatidão de um escritor perspicaz" e com a "eloqüência de um músico apaixonado” (Baudelaire, 2006, p. 44). Além da capacidade de Delacroix de tirar proveito de traços característicos de outros meios (a literatura e a música), Baudelaire exalta o seu poder de sugestão (“o mais sugestivo de todos os pintores”) e a sua capacidade de incitar a reflexão do observador, evocando na sua memória a maior quantidade possível de sentimentos e pensamentos poéticos. Em outro influente ensaio, O Pintor da Vida Moderna, Baudelaire se debruça novamente sobre a obra de um artista visual, desta vez o desenhista Constantin Guys, cujo traço espontâneo, o poeta acredita ser capaz de "fixar a singularidade de um instante", extraindo o eterno da modernidade transitória, efêmera e contingente: "trata-se, para ele, de tirar da moda o que esta pode conter de poético no histórico, de extrair o eterno do transitório” (Baudelaire, 2007, p. 25). É interessante observar, portanto, que Baudelaire parece reverenciar na pintura justamente qualidades que se supunham ausentes nela (qualidades tipicamente atribuídas à poesia), a saber, o poder de sugestão, a capacidade de remeter a uma realidade ausente e, sobretudo, de expressar uma valorização não do espaço, como Lessing espera da pintura, mas do tempo, em toda a sua dimensão efêmera e transitória.

Contra esses mútuos “empréstimos” entre literatura e pintura, o século passado assistiu a um verdadeiro movimento de purificação da representação visual, no qual buscou-se afirmar a sua autonomia em relação à linguagem, à narrativa, à alegoria, aos elementos figurativos e às explicações textuais. Em seu ensaio Rumo a um mais novo Laocoonte (1940), o crítico de arte norte-americano Clement Greenberg resgata as fronteiras estabelecidas por Lessing no século XVIII como uma estratégia para pensar a importância das noções de pureza e especificidade características de cada meio artístico e, mais especificamente, da pintura moderna. Contudo, a incapacidade narrativa da pintura apontada por Lessing é vista por Greenberg como origem da sua força expressiva. O crítico argumenta que, a partir de meados do século XVII, a burguesia mercantil em ascensão, "talvez impelida pela iconoclastia da reforma" havia se voltado para literatura, tornando-a o "protótipo de toda arte”. Como resultado deste predomínio, as outras artes passariam a comprometer as suas características próprias tentando reproduzir os efeitos típicos da obra literária- "Disso resulta uma confusão das artes, pela qual as subservientes são pervertidas e distorcidas; 
são obrigadas a negar sua própria natureza no esforço por alcançar os efeitos da arte dominante" (FERREIRA e COTRIM, 2001, p. 46). Greenberg faz uma comparação entre a poesia chinesa e a pintura ocidental. Em um sentido oposto ao que aconteceria no ocidente, na China as artes dominantes seriam a pintura e a escultura. À poesia, então, caberia o papel subserviente de se concentrar no momento único da pintura e de enfatizar o encanto visual da caligrafia, o que lhe tornaria, na opinião de Greenberg, “um tanto aguada e monótona” quando comparada às artes visuais chinesas. O crítico conclui, assim, que qualquer forma de hibridismo artístico, decorrente da “confusão das artes”, resulta em uma forma de inautenticidade e, consequentemente, de diminuição do potencial expressivo de cada meio. Seu projeto é centrado especificamente na defesa da autonomia da representação visual em relação ao tema, à “anedota” e à “mensagem”. Isenta da responsabilidade de expressar um conteúdo religioso, histórico ou cultural, a pintura passaria a consistir numa experiência puramente ótica, livre de narrativa, alegoria, elementos figurativos e explicações textuais. Para isso, de acordo com a teoria defendida por Greenberg ao longo das décadas de 40 e 50, a pintura deveria aceitar voluntariamente as limitações do seu meio, concentrando-se apenas no que lhe seria específico - cores e formas sobre uma superfície bidimensional. "É em virtude de seu meio que cada arte é única e estritamente ela mesma. Para restaurar a identidade de cada arte, a opacidade de seu meio deve ser enfatizada" (FERREIRA e COTRIM, 2001, p. 54). A manifestação prática mais forte deste pensamento foi o movimento que ficou conhecido como o Expressionismo Abstrato, representado nos Estados Unidos por artistas como Jackson Pollock, Mark Rothko, Franz Kline, Robert Motherwell, e Clyfford Still, entre outros. Sobre o movimento, Greenberg afirmou: “as artes encontram-se agora em segurança, cada uma dentro de suas 'legítimas' fronteiras”. O crítico exalta, ainda, a importância de pintores como Courbet, por ter tentado "reduzir a sua arte a dados sensoriais imediatos" e Manet, cuja “indiferença insolente a seu tema” haveria sido tão revolucionária quanto a própria técnica impressionista. Para afirmar a sua autonomia em relação a referentes externos (os “temas”) a pintura deveria evitar a representação de qualquer objeto nominável, passando a descartar até mesmo o uso dos títulos. Quanto aos signos linguísticos inseridos no espaço da tela (prática mais que comum nas manifestações pictóricas da época) Greenberg os justifica apenas sob o ponto de vista de sua estrutura plana. Neste sentido, o 
crítico entendia que a presença da letra ou da palavra não inseria o discurso no espaço pictórico, mas atestava em favor da superfície bidimensional da tela, e contra o espaço tridimensional representado nas pinturas realistas.

\title{
1.3
}

\section{A pureza dos meios como um "mito modernista"}

Em um livro intitulado Picture Theory, publicado em 1994, W. J. T. Mitchell se coloca a respeito dos confrontos entre imagem e texto nos seguintes termos:

\begin{abstract}
"Uma suposição polêmica de Picture Theory é que a interação entre imagens $e$ textos é constitutiva da representação em si: todos os meios são meios mistos e todas as representações são heterogêneas; não existe arte 'puramente' visual ou verbal, embora o impulso de purificar os meios seja um dos gestos utópicos centrais do modernismo" ${ }^{1}$ (Mitchell, 2004, p. 5).
\end{abstract}

Um ano depois, Mitchell publica um ensaio intitulado There Are No Visual Media (2005), no qual argumenta que todos os meios tradicionalmente considerados "visuais” carregam em si traços de meios não-visuais, o que os tornaria, na verdade, meios híbridos. De acordo com este princípio, uma análise mais detalhada da forma como se constituem e funcionam os meios de expressão revelaria que todas as chamadas “mídias visuais” envolveriam em maior ou menor grau outros sentidos além da visão, sendo, portanto, do ponto de vista sensorial, "mídias mistas". Segundo Mitchell, em determinados meios, tais como o cinema, a televisão ou o teatro, o hibridismo que os constitui mostrar-se-ia tão evidente que a própria tarefa de prová-lo poderia parecer irrelevante. $\mathrm{Na}$ televisão, as imagens são sempre acompanhadas de som e, muitas vezes, também de texto. No teatro, mesmo naquele chamado pejorativamente por Antonin Artaud de "teatro psicológico”, a imagem acústica da palavra falada e a imagem visual dos corpos no palco não deixam de ser tão importantes quanto os significados e as explicações fornecidas pelo texto escrito. E mesmo no cinema mudo, as imagens

\footnotetext{
1 "One polemical claim of Picture Theory is that the interaction of pictures and texts is constitutive of representation as such: all media are mixed media, and all representations are heterogeneous; there are no 'purely' visual or verbal arts, though the impulse to purify media is one of the central utopian gestures of modernism”. Tradução minha.
} 
são acompanhadas de música e palavras escritas, o que o tornaria "qualquer coisa menos mudo" (MITCHELL, 2005, p. 396). A pintura e, mais especificamente, a pintura abstrata seria, então, o meio capaz de oferecer o maior desafio à ideia de que não haveria uma “mídia puramente visual”. Isto porque, como foi visto a partir da teoria defendida por Greenberg, a pintura abstrata, livre de toda a bagagem histórico-cultural carregada pela pintura clássica, teria se tornado uma pintura sem objeto e, desta forma, uma representação plástica que independeria de qualquer elemento lingüístico. Vista em retrospectiva, contudo, e à luz dos movimentos artísticos que se seguiram, a ideia de pureza defendida por Greenberg viria a parecer mais um mito moderno. Em seu livro The Painted Word (1975), Tom Wolfe argumenta que mesmo no movimento no qual se considera que a pintura tenha atingido a sua forma mais "pura”, o Expressionismo Abstrato, um texto servia de pano de fundo para as pinceladas. Entretanto, de forma diversa do que ocorria na pintura de tradição mimética, o texto representado pela pintura abstrata não seria o da bíblia, do mito, da literatura ou dos manuais de história, mas o do discurso da teoria e da crítica de arte. Neste sentido, as linhas, as manchas de tinta, os campos de cor e o célebre dripping de Jackson Pollock não seriam evidências de um estado de autonomia da imagem em relação ao texto, uma vez que constituiriam afirmações sobre a natureza da própria pintura, do espaço pictórico e da representação. A imagem “abstrata”, portanto, não escaparia à esfera da representação e da eloqüência verbal, como havia desejado o impulso moderno de purificação das artes, mas apenas estaria debruçada sobre outro tipo de texto, diferente, mas tão elaborado quanto aquele representado pela pintura figurativa.

Mitchell argumenta, ainda, que para se pensar a questão do hibridismo é necessário, inicialmente, superar a tradicional noção que concebe de forma antitética as ideias de espaço e tempo. Esta oposição não faria sentido, na medida em que a forma espacial seria a base da nossa noção temporal ou, em outras palavras, a nossa percepção do tempo seria mediada pela nossa compreensão do espaço. Uma evidência disso seria o fato do vocabulário de que dispomos para falar de experiências temporais ser inteiramente contaminado por imagens espaciais. Não é possível pensar em períodos “longos” e períodos “curtos”, em “intervalos” (espaços entre dois pontos), em “antes” e “depois”, sem ter em mente uma imagem do tempo como um contínuo linear. Por outro lado, o espaço 
“absoluto”, “simultâneo”, “estático”, e “atemporal” não passaria de uma abstração. Se analisarmos as formas como experimentamos o espaço e, sobretudo, as artes tidas como "espaciais", percebemos que essas formas requerem um processo de apreensão que não se dá sem tempo e movimento. Pinturas e esculturas precisam de tempo para serem percebidas e de movimento para serem exploradas, ainda que este movimento seja apenas o do olhar do espectador. É fácil entender essa afirmação se a pensarmos em relação, por exemplo, às gigantescas estruturas de aço criadas pelo artista americano Richard Serra (figura 1). O espectador que passeia por suas esculturas, placas monumentais erguidas como muros sinuosos, verdadeiros labirintos, percebe que o espaço só pode ser determinado por nossos sentidos em relação à distância que mantém dos nossos corpos. Ao longo do trajeto, as placas de aço maciças e pesadas vão diluindo-se, transformando-se, traçando novas linhas, rearticulando as relações entre a massa construída e o espaço vazio percorrido pelos passantes. No caso de um texto, assim como nas esculturas de Serra, as palavras existem estática e simultaneamente, na medida em que já ocupam um lugar no espaço antes mesmo de serem lidas, mas é preciso lê-las, ou seja, é preciso percorrer os espaços das frases para que o texto comece “a existir”. A disposição das letras em palavras, das palavras em frases, das frases em parágrafos pode nos dar a impressão de que, ao contrário do que ocorre na imagem, o texto se apresenta sequencialmente ao longo do tempo. Mas o ato da leitura é apenas uma maneira convencional de transformar a forma espacial em sequência temporal.

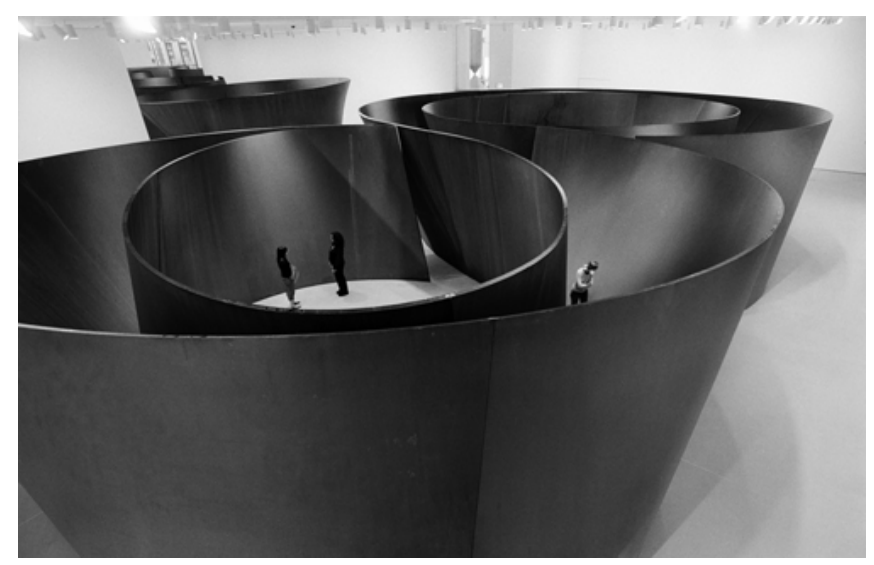

Figura 1. Richard Serra. Tate Gallery, Londres, 1992. 
Mitchell conclui que não é possível experimentar uma forma espacial fora do tempo, da mesma forma que não é possível conceber o tempo sem lançar mão de medidas espaciais, que são essenciais para tornar inteligível a nossa noção de temporalidade. Assim, ao invés de tratar tempo e espaço como modalidades antitéticas, talvez fosse mais interessante pensá-los a partir de uma relação de complementariedade e interdependência. E estabelecer uma relação de complementariedade entre espaço e tempo significa pensar a palavra e a imagem também em termos de interações indissolúveis e não de limites ou fronteiras. É certo que nas últimas décadas, uma série de novas linguagens adotadas pelas artes visuais ajudou a reforçar essa hipótese de que um hibridismo, em maior ou menor grau, seria intrínseco a todos aos meios de expressão. Instalações, performances, arte conceitual, hiperrealismo, o retorno na década de 80 à pintura figurativa e, mais recentemente, as novas formas de arte virtual foram apenas alguns dos movimentos que contribuíam para inviabilizar a noção difundida no modernismo de uma arte puramente visual.

Vistas numa perspectiva histórica, portanto, as barreiras teóricas entre os gêneros e meios artísticos parecem ser cuidadosamente erguidas, mas invariavelmente ultrapassadas, como se a sua construção só se justificasse a partir da descoberta de estratégias cada vez mais engenhosas de cruzamento. Antes de proceder a análise dos efeitos deste hibridismo na obra de Jenny Holzer, gostaríamos de deslocar a atenção para um momento específico no qual este impulso de "violação” deu origem a formas nas quais se verifica o esgarçamento dessas fronteiras. Na década de 50, o movimento da poesia concreta ocorrido no Brasil enfatizou a materialidade da escrita, investiu no uso criativo do suporte do texto e nos aspectos plásticos da palavra escrita, explorando de forma inusitada o desabrochar de uma linguagem híbrida que, poucas décadas mais tarde, viria a se tornar a regra e não mais uma exceção. Seu programa, além de preceder a eclosão de uma série de manifestações da poesia visual, parece antecipar os movimentos que tiram proveito dos meios eletrônicos para investir a palavra escrita de luz, som, ritmo e movimento, entre os quais inclui-se a obra de Jenny Holzer. 


\section{4}

Poesia Concreta: "tensão de palavras-coisas no espaço-tempo"

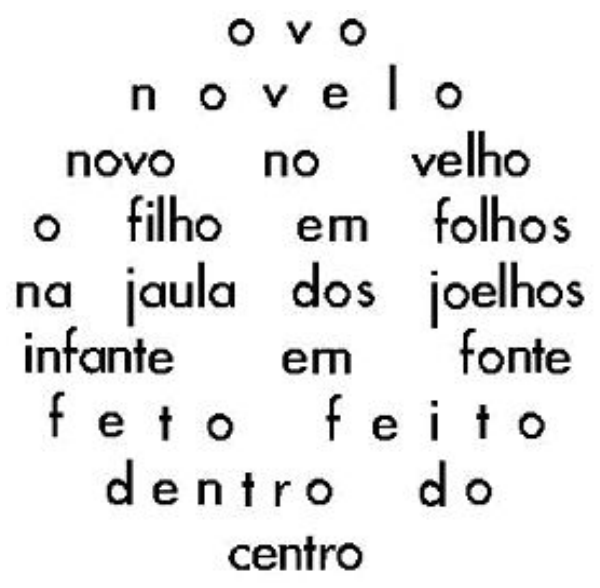

Figura 2. Trecho de “ovonovelo” de Augusto de Campos, 1955.

Em 1897, um ano antes de sua morte, o poeta francês Stéphane Mallarmé publica na revista Cosmopolis o poema Un coup de dés jamais n'abolira le hasard, que de imediato surpreende por sua disposição tipográfica. No seu poema, o aspecto imagético do texto parece recuperar uma importância que fora perdida com o advento da imprensa, no século XV, quando a dimensão visual da palavra, juntamente com a sua origem no gesto manual ou na vocalização, é deixada de lado, o que torna a escrita um meio de expressão mecânico e uniforme. As palavras são impressas em caracteres de diversos tamanhos e espessuras e, tanto a tipografia, quanto a posição das linhas e os espaços em branco da página são manipulados de forma a refletir "com real eficácia as metamorfoses, os fluxos $e$ refluxos do pensamento" (Campos, Pignatari e Campos, 1996, p. 32). Embora ainda não haja ruptura da sintaxe tradicional, a forma como as palavras são distribuídas no espaço se assemelha mais a um concurso de textos autônomos do que propriamente a um poema. O poeta adverte que não se trata de versos, mas de "subdivisões prismáticas da ideia”. Considera-se que foi o estilhaçamento do texto pela página empreendidos por Mallarmé que deu início à “crise do verso” e à espacialização visual do poema sobre a página, que serão exploradas pelo movimento da poesia concreta. "Como processo consciente, pode-se dizer que 
tudo começou com a publicação de Un Coup de Dés (1897), o 'poema-planta' de Mallarmé” (Campos, Pignatari e Campos, 2006, p. 56).

Paralelamente, a crescente influência de teorias que relativizam as noções de tempo e espaço se faz sentir no questionamento da lógica de causalidade que une os elementos da narrativa, bem como no sentido do desenvolvimento linear da história. No plano literário, nota-se que a discursividade característica das línguas ocidentais começa a ceder espaço para uma linguagem mais correlacional e analógica, que afeta a estrutura hierarquizada e determinista da sintaxe. Com efeito, o desenvolvimento linear do texto, seccionado em início, meio e fim, dá lugar a uma organização fragmentada da matéria poética. É neste sentido que Apollinaire aponta para a necessidade de uma compreensão sintético-ideográfica em detrimento da tradicional compreensão analítico-discursiva. Seus Caligramas rompem com a arbitrariedade da relação entre significante e significado, ao empreenderem um processo de representação no qual o discurso verbal é adequado graficamente à forma figurativa do tema do poema (figura 3). Em Isto não é um Cachimbo, Michel Foucault observa que o caligrama conjura a ausência atribuída às palavras, impondo-lhes uma escritura que joga no espaço - “assim, o caligrama pretende apagar ludicamente as mais velhas oposições de nossa civilização alfabética: mostrar e nomear; figurar e dizer; reproduzir e articular; imitar e significar; olhar e ler” (Foucault, 2008, p. 23).

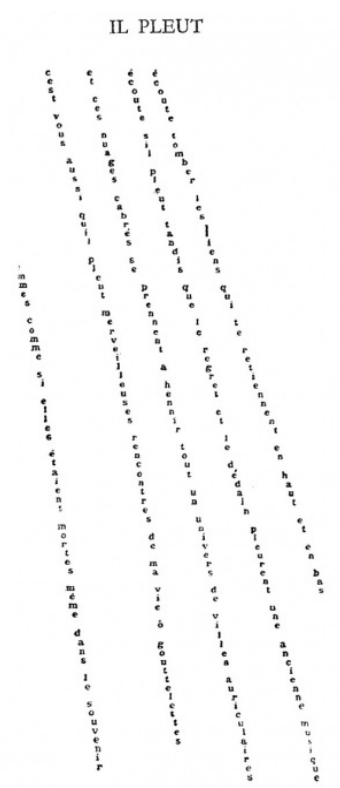

Figura 3. Il Pleu, Guillaume Apollinaire, Paris, 1914. 
A crescente sofisticação dos meios de impressão decorrente do desenvolvimento da imprensa e da publicidade produzem mudanças sensíveis no corpo da escrita. Esse processo abre novas rotas de exploração da dimensão plástica e imagética do código textual, possibilitando que as palavras comecem a se impor também como objetos autônomos e dinâmicos. No Brasil, foram os poetas concretos os primeiros a dar um corpo teórico à questão da visualidade da poesia, colocando programaticamente em discussão as interfaces entre a palavra e a imagem. O que Greenberg via como fraqueza na poesia chinesa - a valorização do espaço, que de acordo com o crítico a tornava "aguada” e "monótona” - passa a ser valorizado e explorado com resultados cada vez mais criativos pelo Movimento da Poesia Concreta. Com ele, a desintegração do verso resultará na desintegração da sintaxe das frases e, em seguida, alcançará as palavras, que serão desmembradas e reunidas em novas composições, em um movimento dinâmico de conquista e exploração das janelas abertas pela visualidade da escrita.

A articulação deslinearizada da composição concreta enfatiza a presença material do signo linguístico, ressaltando o seu aspecto físico, plástico, e a sua capacidade de produzir estímulos sensoriais, geralmente obscurecidos pelo seu status de "invólucro" ou “veículo" de uma mensagem. Neste sentido, Augusto de Campos afirma que a poesia concreta "recusa-se a absorver as palavras como meros veículos indiferentes, sem vida sem personalidade sem história - túmulostabu com que a convenção insiste em sepultar a ideia” (Campos, Pignatari e Campos, 2006, p. 71). Esta concepção da palavra como “veículo indiferente” ou “túmulos-tabu” pode ser vista em diálogo com o estatuto da palavra impressa, como enfatizado por esta passagem do texto de Merleau-Ponty, para quem o ato da leitura faria com que a dimensão física da letra sumisse diante dos significados expressos:

"A maravilha da linguagem é que ela se faz esquecer: sigo com os olhos as linhas no papel e, a partir do momento em que sou tomado por aquilo que elas significam, não as vejo mais. O papel, as letras no papel, meus olhos e meu corpo só estão ali como o mínimo de encenação necessária a alguma operação invisível. A expressão se apaga diante do expresso, e é por isso que seu papel mediador pode passar despercebido [...]" (Merleau-Ponty, 1999, p. 537, grifo meu). 
Convém ressaltar que o Movimento da Poesia Concreta não busca anular a comunicação de significados em favor de uma experiência puramente sensorial, no sentido valorizado por Greenberg na pintura abstrata, ou descartar a estrutura verbal-discursiva em favor unicamente da dimensão espacial ou visual do poema, mas sim de alcançar um equilíbrio entre o estímulo sensível e a transmissão de conteúdos - "um campo de significados entre estímulos óticos, acústicos e significantes”. Busca-se, justamente, desafiar a artificialidade das relações entre significante e significado, forma e conteúdo. O poeta concreto sabe que seu instrumento, a palavra, não pode ser tratado como um elemento completamente neutro, vazio de significado, como se poderia supor que fosse a cor, a forma ou um som. Por isso, não almeja suprimir o conteúdo, mas apenas dotá-lo do mesmo valor conferido aos demais elementos que compõem a poesia. Para isso, assim como parece ocorrer também no trabalho de Holzer, é necessário questionar de forma contundente o entendimento que concebe o conteúdo do texto como essencial e a forma como acessória ou contingente.

Juntamente com o desejo de fundar uma linguagem onde os limites entre forma/conteúdo, significante/significado, palavra/imagem são diluídos, os concretos expressam a vontade de circular livremente entre diferentes fazeres, entre as manifestações da "alta” e da "baixa” cultura, livrando-se das "etiquetas nominativas” que rotulavam as artes. É neste sentido que Haroldo de Campos, referindo-se à poesia, perguntará: "É por acaso um produto de exceção? Um produto de luxo, a ser cultivado numa estufa artesanal, salvaguardado dos contatos com o mundo exterior como uma flor exótica?” (Campos, Pignatari e Campos, 2006, p. 210). Influenciados por poetas como Ezra Pound, para quem a poesia era mais próxima do campo da visualidade e da música do que da linguagem verbal, os concretos defendem, nos seus polêmicos manifestos, a colaboração entre as artes visuais e as artes gráficas e tipográficas na construção de uma arte popular, que circule por entre diferentes campos, como a propaganda, a imprensa, o rádio, a televisão e o cinema. Interessa-lhes mesclar a linguagem poética à linguagem popular, à gíria, à dicção infantil.

Em Além do Olhar Visível (2007), Karl Erik Schollhammer afirma que “o texto depende hoje, mais do que nunca, da sua qualidade visual, da materialidade da escrita, do aspecto gráfico, da edição ou da projeção” (Schollhammer, 2007, p. 17). Torna-se cada vez mais difícil se pensar a forma espacial como um traço 
acessório da literatura e isto fica evidente na tendência de escritores contemporâneos de exercerem um controle cada vez maior sobre o espaço físico das suas publicações. Ao explorar com engenhosidade o aspecto gráfico e visual da palavra escrita, o concretismo já apontava para a necessidade de se conceber o texto sob uma perspectiva que leve em conta além dos significados "por trás das palavras”, a sua dimensão material e toda a complexidade de seus efeitos estéticos. Portanto, é possível estabelecer um diálogo direto entre os propósitos do Movimento da Poesia Concreta e os propósitos de Jenny Holzer que, evidentemente, beneficiando-se da popularização de uma série de novas tecnologias, pode dar uma concretude mais poderosa às ideias compartilhadas pelos poetas concretos brasileiros. É interessante notar, ainda, que já havia entre os membros do grupo noigandres o desejo de experimentar novos meios, tendo, Augusto de Campos, inclusive escrito uma carta ao artista visual Abraham Palatinik, questionando-lhe sobre a possibilidade de fazer uso de luminosos ou filmletras. No mesmo sentido, em uma entrevista concedida em 1957 à revista Diálogo n. 7, Haroldo de Campos afirmará:

"As possibilidades de uma arte combinatória obtida através de meios eletrônicos, cibernética etc., interessam extremamente, como novas perspectivas de organização do material poemático, ao poeta concreto." (Campos, Pignatari e Campos, 2006, p. 148)

A possibilidade vislumbrada por Augusto de Campos na década de 50, de introduzir o código alfabético nos meios eletrônicos, começará a ser explorada por Holzer na década de 80. Suas projeções nas paisagens urbanas e nos espaços fechados das galerias, seus sinais de led e o uso de meios de comunicação de massa, como o telão da Times Square, em Nova Iorque, permitem um trabalho rigoroso de manipulação da temporalidade e do movimento da leitura, mostrando que a expressão direta de ideias não é incompatível com a produção de efeitos sensuais. Nestas situações, o texto é investido não apenas de uma dimensão sensível, que extrapola o âmbito dos significados, mas também de uma dimensão performática, que parece tirar a sua potência, sobretudo, da imprevisibilidade do efeito provocado pelo intervalo entre o contexto e a mensagem. Neste sentido, o trabalho de Holzer se mostra um terreno fértil para uma abordagem que deixa para 
trás as comparações entre a palavra e a imagem e busca entender os possíveis efeitos causados pela interação entre os dois domínios. 


\section{A Performance da palavra escrita}

\section{1}

\section{Truismos}

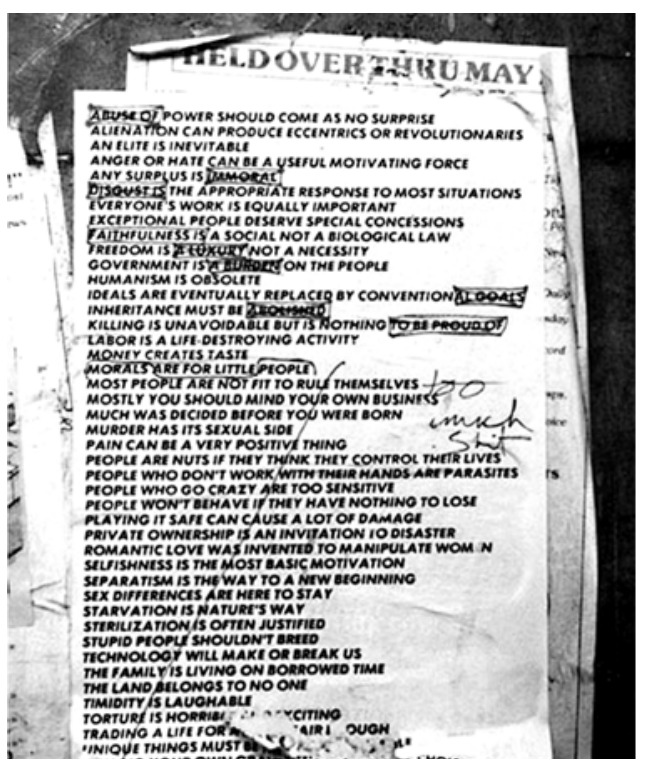

Figura 4 - Truisms, Manhattan, Nova Iorque, 1977.

Em 1977 Jenny Holzer espalha clandestinamente pela cidade de Nova York uma série de pôsteres com frases curtas, de uma linha, impressas em tinta preta e caixa alta sobre um fundo branco (figura 4). O tom das frases é enfático, às vezes infame, quase impositivo, e há convicção e autoridade na forma como as ideias são afirmadas. Passa-se abruptamente de um tema a outro e os sentidos emergem com a mesma velocidade com que são dispensados. São sentidos descartáveis. Contudo, não é possível identificar uma instância autoral, pelo menos não uma única. Pontos de vista antagônicos são apresentados simultaneamente, compartilhando o mesmo tom e a mesma tipografia. Entre as frases, não há hierarquia e nenhuma posição é privilegiada em detrimento das demais. Entre as ideias, nenhuma continuidade, nenhuma sequência lógica de pensamento. Ao contrário, pontos de vista desconexos impedem que se veja coerência na lista de frases organizadas alfabeticamente. Sobre a questão da "voz" 
por trás dos escritos, Jenny Holzer afirmou em 1986, em uma entrevista para revista Art in America: “Eu sempre tento evitar que a minha voz seja identificada. Eu não gostaria de ser uma voz feminina isolada, porque eu acho que quando as coisas são categorizadas elas tendem a ser descartadas. "2 A linguagem transita em meio à literatura, à filosofia, aos chavões populares, à linguagem da propaganda e das mensagens oficiais, contribuindo para diminuir as distâncias (supõe-se que alguma distância deva existir) que separam essas escritas.

\author{
ABUSE OF POWER SHOULD COME AS NO SURPRISE \\ AN ELITE IS INEVITABLE \\ ANY SURPLUS IS IMMORAL \\ EVERYONE'S WORK IS EQUALLY IMPORTANT \\ EXCEPTIONAL PEOPLE DESERVE SPECIAL CONCESSIONS \\ FAITHFULNESS IS A SOCIAL NOT A BIOLOGICAL LAW \\ FREEDOM IS A LUXURY NOT A NECESSITY \\ GOVERNEMENT IS A BURDEN ON THE PEOPLE \\ HUMANISM IS OBSOLETE \\ IDEALS ARE EVENTUALLY REPLACED BY CONVENTIONAL GOALS \\ MONEY CREATES TASTE \\ MORALS ARE FOR LITTLE PEOPLE \\ MURDER HAS ITS SEXUAL SIDE \\ PRIVATE OWNERSHIP IS AN INVITATION O DISASTER \\ STERILIZATION IS OFTEN JUSTIFIED \\ STUPID PEOPLE SHOULD NOT REPRODUCE
}

\title{
$[\ldots]$
}

Jenny Holzer aponta como fonte de seus primeiros textos a "enorme lista de livros sérios, e às vezes opacos, tudo de Marx ao estruturalismo"3 que recebeu de seu professor Ron Clark enquanto cursava o Whitney Independent Study Program, entre 1976 e 1977. Segundo Holzer, havia um desejo de descobrir o que

\footnotetext{
2 FERGUNSON, B. "Wordsmith: an interview with Jenny Holzer". Art in America, December, 1986, p. 111. "I always try to make my voice unidentifiable. I wouldn't want to be isolated as a woman's voice, because I've found that when things are categorised they tend to be dismissed. I find it better to have no particular associations attached to the voice in order for it to be perceived as true. Yet, I do want my voice to be heard and, yes, it's a woman's voice.” Tradução minha.

${ }^{3}$ I wanted to sort out what I was to do, or what anyone was to do, with that much dense and sometimes contradictory information. So I rewrote his library. I did it as a self-help maneuver, and pasted the results - the Truisms - in the streets. Madoff, Steven H. "Jenny Holzer talks to Steven Henry Madoff” Artforum International. 41.8 (2003): p. 82-83. Tradução minha.
} 
poderia ser feito com aquela quantidade enorme de informação. A resposta veio na forma de uma rescritura que deu origem à célebre série Truisms e tornou Holzer conhecida no cenário das artes. ${ }^{4}$ Neste projeto, teorias da cultura ocidental e crenças populares são condensadas em frases sucintas - "microteorias", truismos.

Na série que se seguiu a Truisms, intitulada Inflammatory Essays (19791982), as frases de uma linha se tornaram parágrafos de cem palavras. Inspirada em escritos de figuras emblemáticas, como Mao Tse-Tung, Adolf Hitler, Vladimir Lênin, Leon Trotsky e Emma Goldman, a série foi escrita em um tom mais “inflamado”, bem diferente do estilo neutro e factual dos truísmos, e impressa, em itálico e negrito, em pôsteres pintados com cores vivas. As variações na escrita foram acompanhadas por variações nos meios e o formato simples dos primeiros pôsteres logo deu lugar a uma série de diferentes suportes - bonés, camisas, recibos de caixa registradora, performances de dança, placas de bronze, preservativos, sinais eletrônicos, bancos de mármore, internet, sarcófagos, entre diversos outros (figura 5). Desta maneira, as contingências materiais e contextuais que articulavam o texto logo se provaram tão importantes para o trabalho quanto as mensagens que elas traziam. Descontextualizados e cuidadosamente recontextualizados seus textos passaram a estabelecer com os leitores/espectadores relações que iriam muito além da leitura.

\footnotetext{
${ }^{4} \mathrm{O}$ termo "truism" é definido como uma verdade "inconteste, evidente, óbvia demais para ser mencionada", o que parece justificar a convicção com que as frases são afirmadas. Merriam Webster. Definition of truism: an undoubted or self-evident truth; especially : one too obvious for mention. In: http://www.merriam-webster.com/dictionary/truism
} 


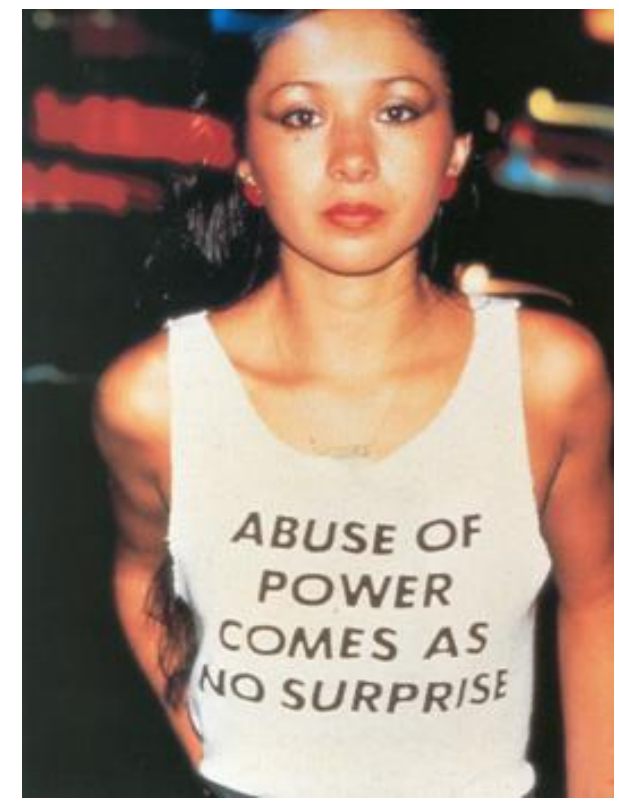

Figura 5. Jenny Holzer. Truisms, (1977-79).

T-shirt usada por Lady Pink, NY, 1983.

\section{2}

\section{Desmembrando forma e conteúdo}

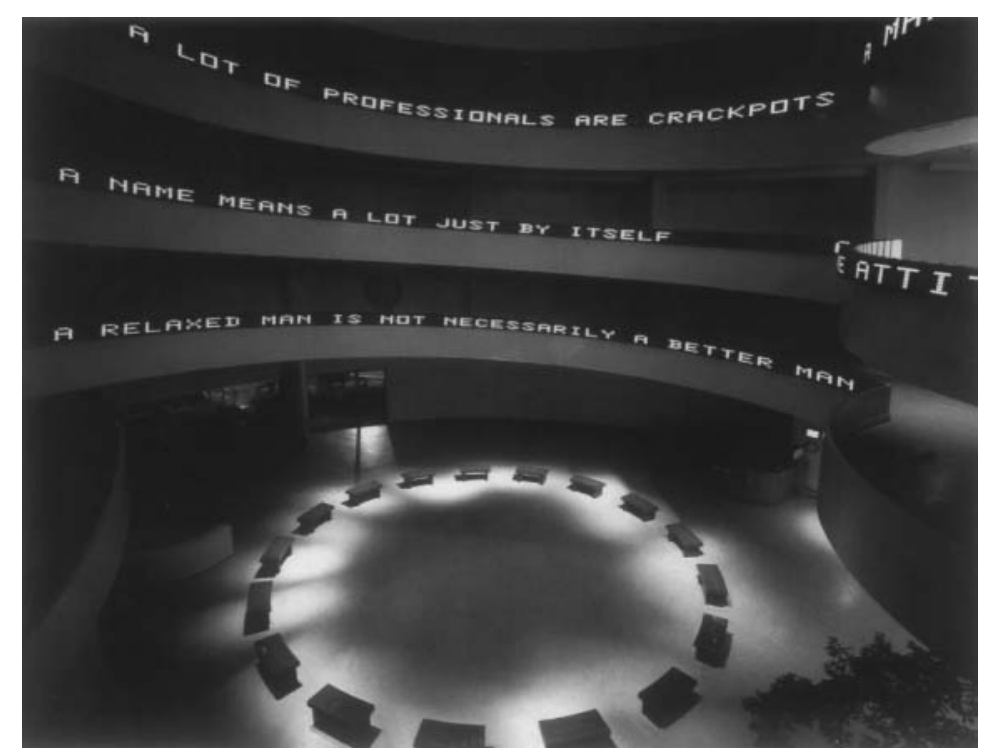

Figura 6 - Jenny Holzer. Instalação Museu Solomon R. Guggenheim, Nova Iorque, 1990.

Tem sido uma prática comum abordar a obra de Jenny Holzer a partir de uma separação entre conteúdo e forma, onde o estudo do sentido do texto é privilegiado em detrimento de uma pesquisa sobre o suporte, ao qual se atribui um 
caráter acidental ou acessório. Essas abordagens tendem a situar a obra de Holzer dentro de um processo que tem início com a Arte Conceitual nas décadas de 60 e 70, e a relacioná-la com questões teóricas típicas do que se caracterizou como o “pós-modernismo”. Em A Condição Pós-Moderna (1979), considerado um dos escritos fundacionais deste debate, Jean-François Lyotard define a pósmodernidade a partir do esvaziamento das grandes narrativas ideológicas do mundo moderno (como o iluminismo, o idealismo e o marxismo), chamando atenção para o ceticismo com que esses metarrelatos produzidos no século XIX passam a ser vistos pela sociedade pós-industrial. Essas narrativas, vistas agora como fábulas, ao tentarem explicar a condição do homem ocidental, acabariam engendrando um processo de homogeneização que serviria para aplacar diferenças e pluralidades. Contra a teleologia e a totalização dos metarrelatos, passar-se-ia a valorizar as pequenas intensidades estéticas - o pequeno relato, a escrita descontínua, o fragmento - enfim, uma multiplicidade de pequenos discursos, ou jogos de linguagem, que desafiariam a configuração da narrativa orgânica e ordenada, organizada em início, meio e fim. A atual popularidade de autores que adotam um estilo aforístico, como Nietzsche e Wittgenstein, pode ser vista como um dos indícios da crise de legitimidade que o pensamento unívoco e a retórica da totalidade têm enfrentado. Da mesma forma, as frases escolhidas por Jenny Holzer parecem participar deste movimento de esfacelamento de uma escrita lógica e linear. Ao aproximar ideias, em princípio, incompatíveis, como, $O$ TRABALHO DE TODAS AS PESSOAS É IGUALMENTE IMPORTANTE e PESSOAS ESPECIAIS MERECEM CONCESSÕES ESPECIAIS, a escrita parece querer frustrar as tentativas de uma leitura coerente e escapar à armadilha de, pelo uso de uma linguagem clara e direta, tornar-se didática. Em Art Since 1900 (2007), Hal Foster argumenta que o pós-modernismo tem sido marcado por duas atitudes distintas em relação às artes visuais - uma "neoconservadora" e outra "pós-estruturalista”. Segundo o autor, o "pós-modernismo neoconservador" consistiria numa espécie de reação contra o modernismo, contra as experimentações linguísticas na literatura, o abstracionismo na pintura e o funcionalismo na arquitetura. Neste sentido, defenderia um retorno a valores estéticos “pré-modernos”, à narrativa tradicional, à figuração e ao ornamento. Uma parte importante desse processo seria a revalorização das noções de originalidade, individualidade artística e autoria problematizadas ao longo do 
século XX. Em sentido oposto, na versão “pós-estruturalista”, o pós-modernismo consistiria justamente num avanço ao questionamento de tais noções. No lugar de um retorno à representação, o "pós-modernismo pós-estruturalista” se proporia justamente a denunciar a sua falência, aprofundando a ideia de que a representação não imita a realidade, mas a constitui. No que diz respeito à literatura, por exemplo, questiona-se de forma contundente a tradicional continuidade entre os signos e a realidade na qual se apoia a ideia de representação. Torna-se claro que qualquer desejo de fidelidade ao mundo extratextual estará sempre submetido à linguagem, que não pode mais ser pensada através da metáfora do "vidro transparente", através do qual uma determinada realidade possa ser vista, mas, antes, como um fator de opacidade. Desta forma, não seria dado à linguagem transpor sem fraturas ou distorções a experiência para o texto, o que impossibilitaria o encontro com o referente da escrita. O pressuposto de autonomia da linguagem a tornaria, assim, criadora ou constitutiva de sua própria realidade e não porta-voz de uma realidade anterior. Qualquer elaboração linguística, portanto, operaria um deslocamento, resultando em algo outro, distinto do dado empírico ou do referente primeiro. Em relação às práticas artísticas, esse pensamento se traduz, ainda, no abandono da noção moderna de “obra”, como um todo simbólico, único e autônomo, e na valorização da ideia pós-moderna do "texto”, concebido por Roland Barthes como “um espaço de dimensões múltiplas, onde se casam e se contestam escrituras variadas, das quais nenhuma é original”, ou ainda como “um tecido de citações oriundas dos mil focos da cultura” (Barthes, 2004, p. 62). A desmistificação da ideia de texto original concorre para a desmistificação da figura do autor como centro autônomo fundador do discurso. Segundo Foster, essa noção de textualidade se adéqua muito bem à estratégia de veiculação de escritos anônimos usada por Holzer. Seus textos fragmentados e anônimos participariam, assim, de um movimento mais amplo de exposição e desconstrução do mito ideológico da origem, tanto em relação ao "grande artista", quanto em relação à "grande obra” (Foster, 2007, p. 598).

A recusa estratégica de Holzer em identificar uma instância autoral parece justamente aumentar a responsabilidade do leitor/espectador ao lidar com o texto. Este pensamento, afirmado explicitamente em um dos truismos - VOCÉ $E ́$ RESPONSÁVEL POR CONSTRUIR O SENTIDO DAS COISAS - é comumente 
relacionado pela crítica à noção de morte do autor defendida por Roland Barthes, segundo a qual "o nascimento do leitor deve pagar-se com a morte do autor". Barthes propõe que a linguagem seja colocada no lugar do autor, que este recue e a deixe falar. Propõe a morte do autor como condição para o nascimento da escritura. Ao aproximar ideias em princípio contrastantes e escolher frases que privilegiam o caráter imprevisível e volátil da linguagem, Holzer convoca uma participação mais ativa do observador, ou, como colocado por David Joselit, "Holzer induz implicitamente o espectador a assumir uma posição" (Joselit, 2003, p. 48). É neste sentido que Gordon Hughes observa que uma frase como UMA ELITE É INEVITÁVEL pode ser lida como fascista, marxista, socialdarwinista ou nietzscheana, dependendo de quando, como, onde e, sobretudo, de por quem é lida (Hughes, 2006, p. 431-432). As frases, descontextualizadas e anônimas, não podem se abrigar no esconderijo seguro de grandes ideologias ou escolas de pensamento que lhes prescrevam o sentido - "Uma vez afastado o Autor, a pretensão de 'decifrar' um texto se torna totalmente inútil. Dar ao texto um Autor é impor-lhe um travão, é provê-lo de um significado último,é fechar a escritura" (Barthes, 2004. p. 63). Barthes chama a atenção para a forma como essa noção de autoria convém à crítica que se propõe a “desvendar” a obra. Esta crítica sustenta-se sobre a premissa de que uma vez descoberto o autor, encontrase o sentido por trás do texto - "encontrado o Autor, o texto está 'explicado', o crítico venceu” (Barthes, 2004. p. 63). Privada da figura do autor, contudo, a escritura pode apenas ser deslindada, desfiada mas nunca decifrada, uma vez que não há um sentido último a ser encontrado.

Em 2001, o desejo de projetar outras vozes é levado para outro patamar quando Holzer pára de escrever os textos e passa a se apropriar de vozes reais, não ficcionais - citações retiradas de uma série de diferentes escritos, como diários, cartas, poemas, entrevistas, textos jornalísticos e documentos oficiais do governo americano. Ao entremear a sua voz a outras vozes reais, o trabalho promove uma fusão dos diferentes processos de autoria onde a escrita é dissolvida no contínuo da linguagem e enfatizada como um processo de colaboração. Sobre o assunto, David Joselit afirma que Holzer utiliza a linguagem não apenas "para desmaterializar os objetos de arte, mas para evaporar o sujeito da arte - o artista [...] para desmaterializar o autor" (Joselit, 1998. p 45). Ao evitar a projeção de uma identidade singular, seus textos conseguiriam levar a linguagem a um ponto 
onde as qualidades da figura autoral - incluindo as de gênero - são tornadas irrelevantes. É neste sentido que o trabalho de Holzer é visto como um desdobramento da Arte Conceitual, capaz de desmaterializar, além do objeto da arte (dissolvido na linguagem), também o seu sujeito.

Concordamos com Joselit quando ele afirma que na obra de Holzer há um recuo deliberado da figura autoral. Contudo, conceber a sua linguagem como “desmaterializada”, ou seja, anterior ou independente das contingências materiais e contextuais que integram o trabalho parece ser ignorar um aspecto significativo, ou (no entendimento da presente pesquisa), mais que isso, fundamental da obra. Este pensamento pressupõe uma visão essencialista da linguagem, uma concepção da linguagem como sistema de representação de sentidos que transcenderiam a forma, concepção que entendemos ser incompatível com a trajetória da artista. As frases escolhidas por Holzer, ao privilegiarem o caráter polissêmico da linguagem, frustram as tentativas de conectá-la a sentidos que preexistam a sua materialização. Em outras palavras, os textos parecem esvaziados de valor fora do contexto em que ganham materialidade, pois é a partir de uma série específica de contingências que o sentido do trabalho é articulado e delimitado. Embora o texto seja, sem dúvida, o elemento predominante no percurso da artista, entendemos que é a forma cuidadosa como ela situa as palavras no espaço, costurando o visual ao discursivo, que torna a experiência do espectador diferente da leitura. Na sua obra, as palavras rasgam as fronteiras que lhes são tradicionalmente impostas e investem-se da presença própria da imagem, seduzindo o observador por seu conteúdo provocador quando por sua aparência cuidadosa. Seu trabalho, hoje, caracteriza-se não apenas pela utilização do texto, como também por uma beleza sensual e pelo uso de efeitos impressionantes que vão do emprego de cor, ritmo, luz e movimento à produção de projeções em escalas monumentais. Não há dúvidas em relação ao fato de que uma explicação, ou mesmo um título, pode determinar em grande parte a forma como olhamos uma imagem. Então, em um sentido inverso, o trabalho de Holzer parece colocar a seguinte questão: de que maneira os aspectos visuais/materiais de um texto podem influenciar a forma como o lemos? 


\section{3}

\section{Complexos Imagético-Textuais}

Em 1993, o truismo MEN DON'T PROTECT YOU ANYMORE (“os homens não protegem mais você”) apareceu na marquise do Liberty Theater em Nova Iorque, um teatro situado na rua 42, entre a sétima e a oitava avenida. O teatro, que nos anos quarenta havia sido palco de grandes musicais, tornara-se um alvo frequente de crimes violentos e acabara fechando nos anos 80. O local havia se tornado um dos mais perigosos da cidade, figurando no topo das estatísticas de violência urbana. Proteção e segurança, portanto, eram algumas das principais questões sugeridas por aquele contexto. Assim, MEN (os homens) podia ser entendido como a polícia, ou o estado, e YOU (você ou vocês) como a população em geral, ou, mais especificamente, os habitantes ou frequentadores daquela região. Mas a mesma frase, “MEN DON'T PROTECT YOU ANYMORE”, tem seu sentido inteiramente rearticulado quando aparece na embalagem plástica de preservativos em 1983 (figura 7). A camisinha redireciona o sentido do sujeito do enunciado, MEN (homens), que passa a ser pensado não mais como a polícia, ou alguma outra autoridade, mas como homens, parceiros sexuais do sexo masculino e potenciais usuário de preservativos. Já o perigo, implícito em PROTECT (protegem), passa a não ser mais o da violência urbana, dos furtos, roubos e assassinatos, mas sim o da saúde física, ameaçada principalmente pela AIDS, cuja epidemia na década de 80 deixara em alerta sobretudo as populações de grandes metrópoles como Nova Iorque. É possível dizer, portanto, que o trabalho de Holzer se afasta da arte conceitual, uma vez que concebe a materialidade da escrita não como um aspecto perfunctório, para usar o termo de Sol Lewitt, mas como parte essencial do próprio conteúdo do texto. Desta forma, explicita a noção de que o significado é mais uma construção circunstancial do que uma apreensão platônica da ideia. 


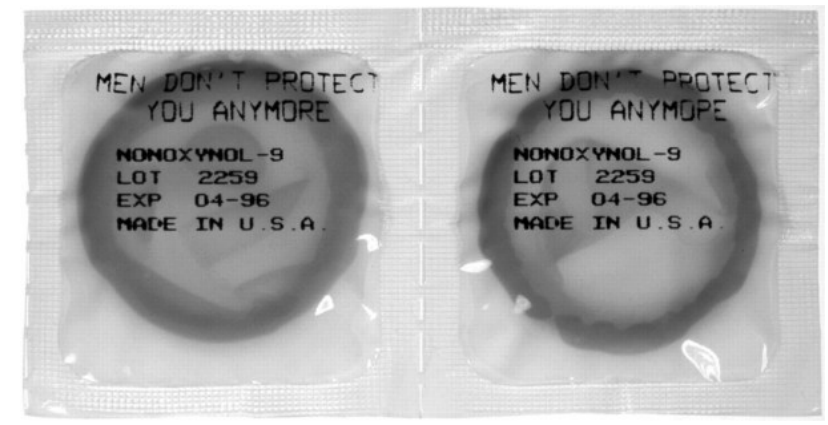

Figura 7. Jenny Holzer, condom, Men Don’t Protect You Anymore 1983-85

Assim como as contingências materiais estão constantemente promovendo a atualização dos significados construídos a partir dos textos de Holzer, a operação inversa também ocorre, ou seja, o conteúdo dos textos é capaz de promover a ressignificação dos aspectos visuais e materiais da obra. Em alguns momentos, estes aspectos apontam no mesmo sentido dos enunciados, formando um complexo orgânico no qual palavra, imagem e suporte parecem se confundir. Um bom exemplo desta fusão são os bancos de granito utilizados na série Under a Rock (1986). Os textos, que utilizam uma linguagem gráfica e precisa para abordar o tema da violência e da morte, são inscritos em bancos de pedra, com a tipografia comumente adotada pelos cemitérios americanos, evocando inevitáveis analogias com lápides e sepulturas. Em outros momentos, o trabalho tira proveito justamente de uma dissonância ou de um intervalo entre o meio e a mensagem. A dualidade entre uma atmosfera visualmente atraente e uma mensagem perturbadora é explorada em muitos trabalhos de Holzer, dos quais é um exemplo a série de esculturas eletrônicas True Ribs (“costelas verdadeiras”) de 2008 (Figura 8). 


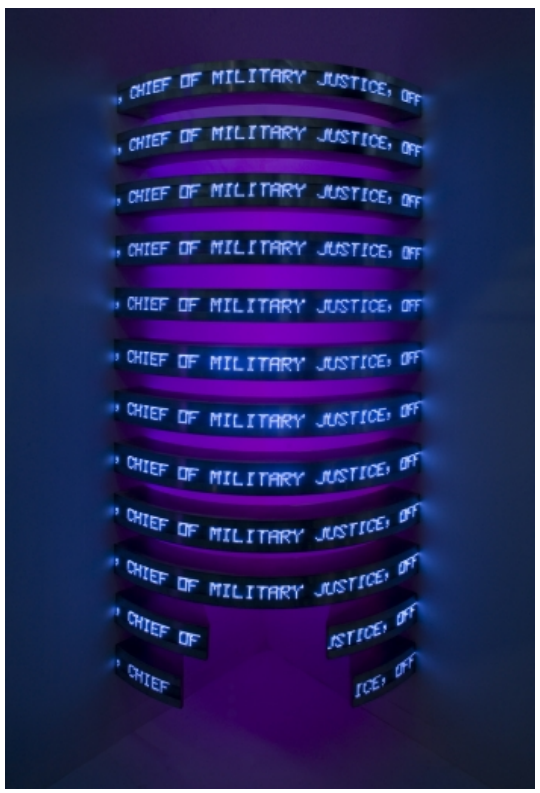

Figura 8. Jenny Holzer, True Ribs, 2008

Neste trabalho, vários sinais de LED atravessam paralelamente o canto de uma sala, formando um arco entre as duas paredes. A presença escultural da estrutura, aliada à luminosidade em tons de azul e lilás dos textos, evoca analogias com a serialidade das elegantes caixas retangulares de Donald Judd e com os tubos fluorescentes de Dan Flavin. Os textos que percorrem os sinais eletrônicos, contudo, incluem trechos retirados de arquivos sobre atrocidades cometidas por militares americanos no Oriente Médio e documentos do governo americano que relatam procedimentos ilegais na prisão de Guantánamo, em Cuba. A leitura das frases, neste caso, promove uma ressignificação da forma visual do trabalho, que passa a convocar analogias com “jaulas”, “gaiolas” ou, como sugere o título da obra, com as "costelas” do esqueleto humano (figuras 9 e 10). A forma como Holzer utiliza a linguagem e os suportes parece ecoar a definição feita por W. J. T. Mitchell de meio ou mídia. Mitchell argumenta em favor de uma noção de “mídia” concebida não como uma essência singular, ditada por alguma técnica ou tecnologia, mas como uma "prática sócio-material”, composta não apenas de elementos materiais e tecnológicos, mas também de habilidades, costumes, práticas culturais, sociais e mercadológicas (MITCHELL, 2005, p. 399). 


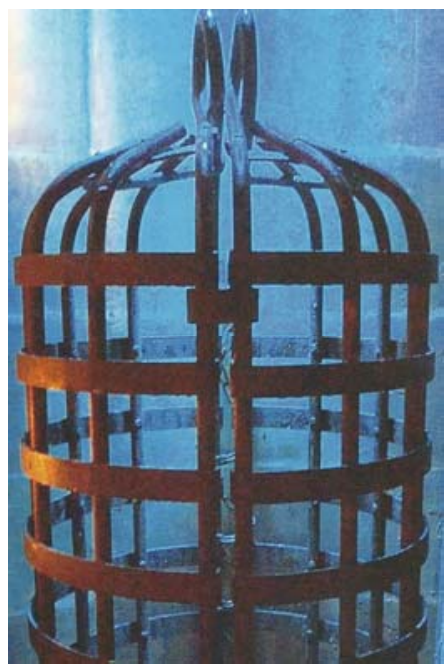

Figura 9 - Jaula.

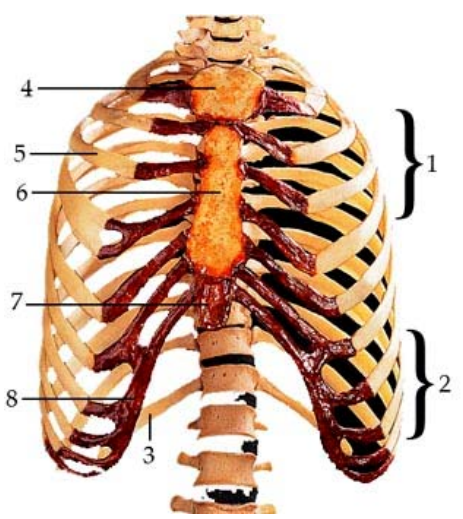

Figura 10 - "True Ribs”

\section{4}

"Big Brother Media"

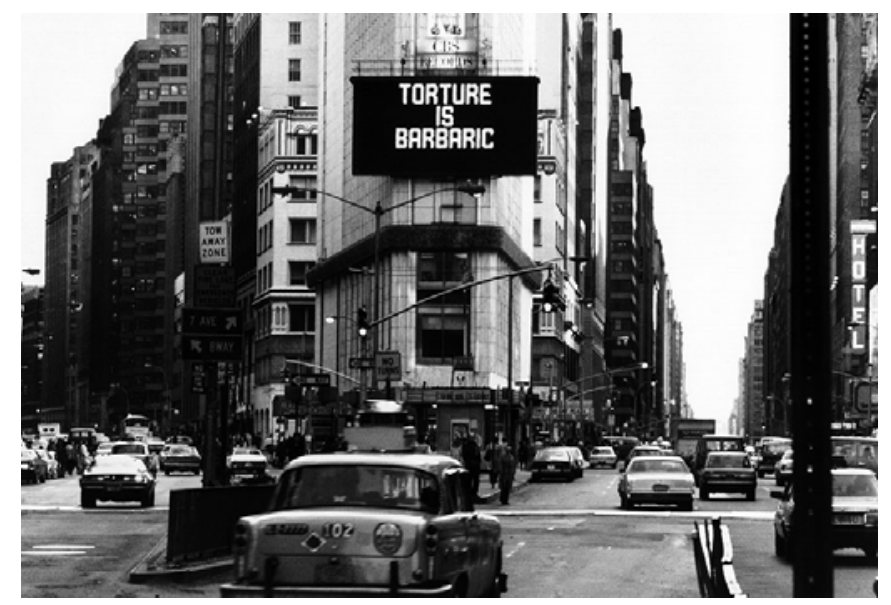

Figura 11 - Spectacolor Board, Times Square, Nova Iorque, 1982. 
Em 1975, quatro anos antes de dar início à série Truisms, Jenny Holzer trabalhou em um projeto que recebeu o nome de Pigeon Lines (linhas de pombos), no qual migalhas de pão eram dispostas de acordo com padrões de figuras geométricas no chão de uma praça em Rhode Island. A ideia era que as pessoas que passassem pelo local tivessem a sua atenção capturada por uma imagem inusitada, a de pombos, comendo, organizados na forma, por exemplo, de um triângulo ou de um quadrado. Holzer conta que na época percebeu que "o trabalho não era bonito o suficiente, ou convincente o suficiente, ou inteligível o suficiente para fazer as pessoas pararem” (Waldman, 1997, p.18). Mesmo assim, já é possível perceber aqui duas características que acompanhariam a obra da artista nas décadas seguintes, a saber, o desejo de interferir no caminho cotidiano dos passantes e o desejo de incorporar a esta interferência algo inesperado, algo capaz abrir uma fenda na avalanche informativa da cidade e se impor por uma diferença irreconciliável em relação ao seu conteúdo. Estes desejos fazem com que Holzer, a partir do início da década de 80, comece a fazer uso do que ela chama de "Big Brother Media" 5 - meios de comunicação de massa que marcam uma presença ostensiva na paisagem urbana. Ao usar a cidade como suporte, apropriando-se dos seus meios de comunicação para transgredi-los, o trabalho de Jenny Holzer consegue interferir performaticamente na realidade em que se insere, apresentando-se como um impulso de resistência capaz de medir forças com a plurirrealidade da metrópole. É neste sentido que Hal Foster comenta que a artista concebe o espaço público ao mesmo tempo como "um alvo e uma arma" (Foster, 1986, p. 36).

Na série Living (1980-1982) os pôsteres das séries anteriores, Truisms (1977-79) e Inflammatory Essays (1979-82), dão lugar a placas de bronze, que passam a ser coladas nas paredes de ruas, pontos turísticos e prédios institucionais, como o MOMA, em Nova Iorque. Utilizando-se do material, do formato e da tipografia característicos das placas que trazem informações sobre monumentos históricos, os textos de Holzer passam a se apropriar da autoridade reservada às mensagens oficiais e institucionais. (figuras 11 e 12). Este seria o

\footnotetext{
${ }^{5}$ Jenny Holzer usou o termo em entrevista concedida em 1999, no Rio de Janeiro, por ocasião de sua exposição no Centro Cultural do Banco do Brasil. http://www.youtube.com/watch?v=Prrad2nfeLM\&feature=autoplay\&list=PLFF2509421074188B \&lf=results_main\&playnext $=2$
} 
início de um processo cujos efeitos se acentuariam, na medida em que o trabalho fosse conquistando alguns meios do circuito dominante da comunicação e da publicidade urbana, como o telão da Times Square, em Nova Iorque.

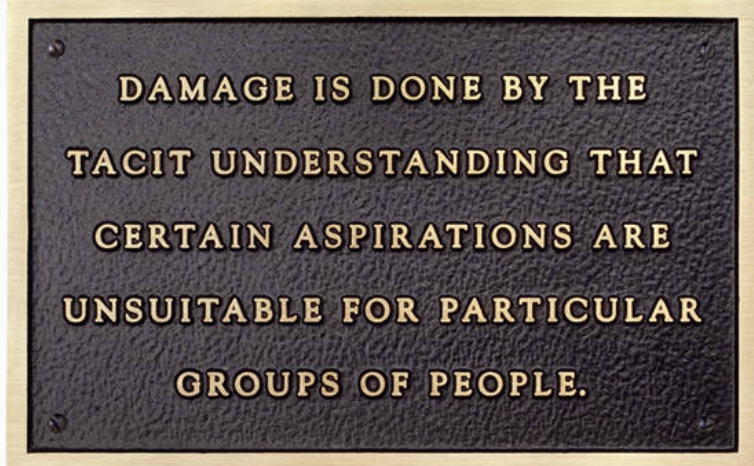

Figura 12. Jenny Holzer, 'Damage is done...' texto da série Living (1980-1982), 1981.

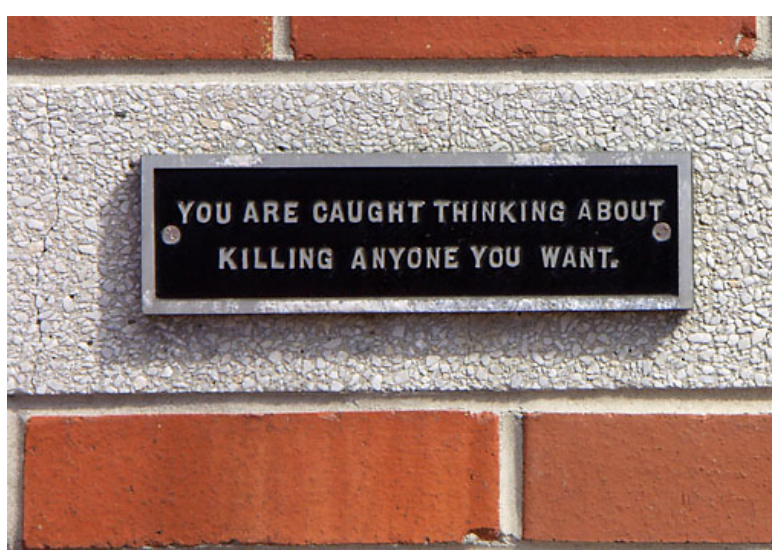

Figura 13. Jenny Holzer, 'You are caught...' texto da série Living (1980-1982).

A carga visual excessiva que compõe o espaço urbano contemporâneo promove uma reconfiguração da paisagem, articulando uma nova visualidade, onde a profundidade é substituída por uma superfície planar e onde inúmeros ângulos e perspectivas se sobrepõem, passando a ser percebidos simultaneamente. Em geral, os signos da cidade midiática são aqueles que não solicitam resposta do observador, que não oferecem possibilidade de diálogo ou de transcendência do sentido. Ao invés disso, eles se impõem ao olhar do passante e estabelecem com ele uma relação unilateral, onde não há espaço, e geralmente nem tempo, para reflexão ou questionamento. O sinal de trânsito proibindo um retorno, o relógio público que informa a hora (e, em seguida, a temperatura), o símbolo do cigarro 
cortado por uma linha diagonal que adverte sobre a proibição de fumar, a foto publicitária e os sinais eletrônicos que trazem as informações sobre o tráfego na hora do rush são todos exemplos desses signos aos quais não se pode acrescentar nada. No tecido urbano, sinais de trânsito, mensagens institucionais, propaganda política, publicidade e notícias alternam-se e confundem-se, produzindo a aparência de uma falsa homogeneidade que o passante certamente não se dispõe a questionar. Como bem nos lembra Marc Augé:

"É preciso constatar que se misturam diariamente nas telas do planeta as imagens da informação, da publicidade e da ficção, cujo trabalho e cuja finalidade não são idênticos, pelo menos em princípio, mas que compõem, debaixo de nossos olhos, um universo relativamente homogêneo em sua diversidade” (Augé, 2004, p. 34).

Holzer comenta que o anonimato das frases contribui para que elas sejam “percebidas como verdades”. No que pode parecer uma contradição, ela continua afirmando que "ainda assim, eu quero que a minha voz seja ouvida e, sim, é uma voz de mulher" ${ }^{6}$. O aparente paradoxo encontrado na declaração de Jenny Holzer - que a sua voz seja ao mesmo tempo indeterminada $e$ identificada como sua (uma voz feminina) - não deixa de ser o mesmo paradoxo da linguagem encontrada nos meios de comunicação de massa dos quais ela se apropria para veicular seus textos. Essa "linguagem oficial” lança mão de um estilo impessoal e de uma aparente neutralidade que apagam os vestígios que a levariam a sua origem. Apesar de conterem uma finalidade inequívoca e de serem atualizados com a velocidade característica da era digital, são textos que parecem não ter sido escritos por ninguém, que dão a impressão de terem sempre estado ali, integrando a paisagem urbana. A diversidade de ideologias veiculadas por Holzer nos meios de comunicação de massa, suas frases antagônicas e incompatíveis, não apenas expõem contradições na estrutura discursiva dos signos linguísticos urbanos, como também apontam para a multiplicidade de opiniões e ideais que compartilham o espaço comum da cidade.

\footnotetext{
${ }^{6}$ FERGUNSON, B. "Wordsmith: an interview with Jenny Holzer”. Art in America, December, 1986, p. 111. “I always try to make my voice unidentifiable. I wouldn't want to be isolated as a woman's voice, because I've found that when things are categorised they tend to be dismissed. I find it better to have no particular associations attached to the voice in order for it to be perceived as true. Yet, I do want my voice to be heard and, yes, it's a woman's voice.” Tradução minha.
} 
Ao veicular frases como PESSOAS BURRAS NÃO DEVERIAM PROCRIAR ou A FALTA DE CARISMA PODE SER FATAL no quadro de avisos do aeroporto de Las Vegas, ou, “A PROPRIEDADE PRIVADA CRIOU O CRIME” no telão da Times Square, ou ainda, O ASSASSINATO TEM SEU LADO SEXUAL no relógio de Washington, Holzer promove uma confusão entre os discursos públicos e privados. Essa estratégia permite que pensamentos particulares sejam lidos, ainda que por um breve instante, como mensagens oficiais, explicitando, ainda, a maneira como o suporte do texto, ao menos em parte, é capaz de pré-determinar uma postura de leitura. O que parece desconcertante para o espectador não é tanto o conteúdo dos escritos (muitos deles são banais), mas o desajuste entre o conteúdo e o suporte, entre a mensagem e o meio. A frase que afirma que a propriedade privada criou o crime, apresentada em letras gigantescas em um dos maiores centros comerciais do mundo, causa o estranhamento necessário para interromper bruscamente o fluxo repetitivo e aparentemente homogêneo dos enunciados que compõem aquele espaço (figura 11). Essa estratégia parece abrir uma fresta na epiderme urbana, evidenciando seus processos internos, a forma como o poder econômico e político é exercido de forma eloquente e ostensiva na arquitetura da cidade tentando, contudo, apagar os vestígios que evidenciam a sua origem. As intervenções públicas de Holzer funcionam como um convite para que se reflita acerca dessas questões. Participam da difícil tarefa de encorajar o passante “anestesiado” a devolver o olhar para a cidade, a questionar e responder os enunciados que lhes são impostos. São estímulos que cobram de um espectador passivo alguma reação, sem, no entanto, prescrevê-la de antemão, numa tentativa, talvez, de restituir-lhes uma percepção pessoal, subjetiva e crítica sobre o seu entorno. 


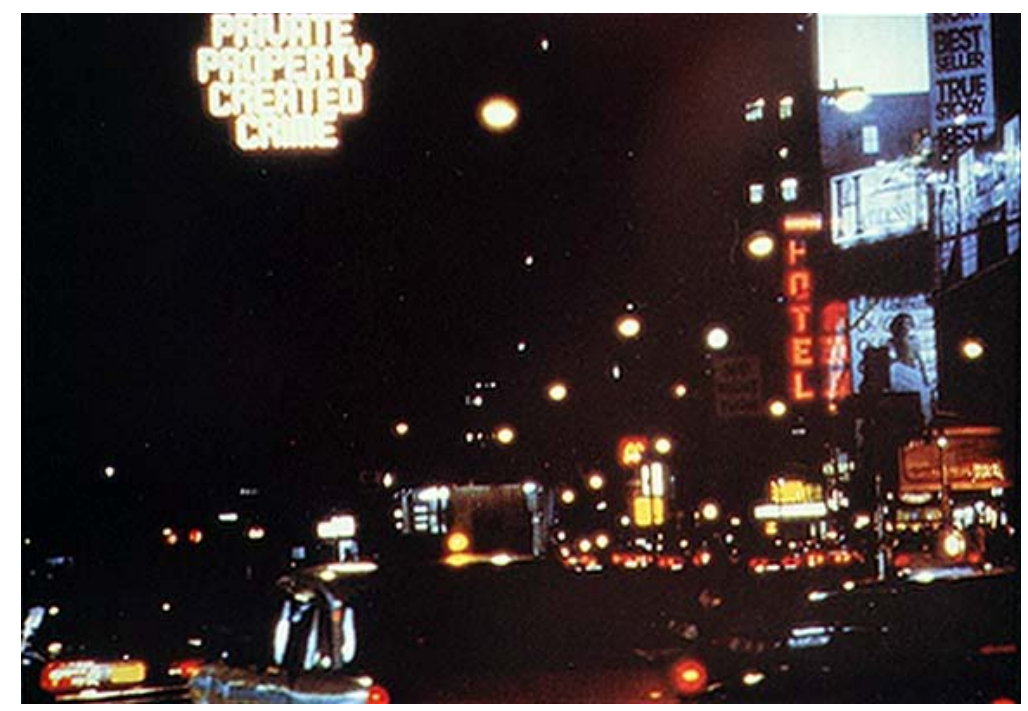

Figura 14. Jenny Holzer, série Truisms (1977-1979) Spectacolor Board, Times Square, Nova Iorque, 1982.

\section{5}

Desacelerar

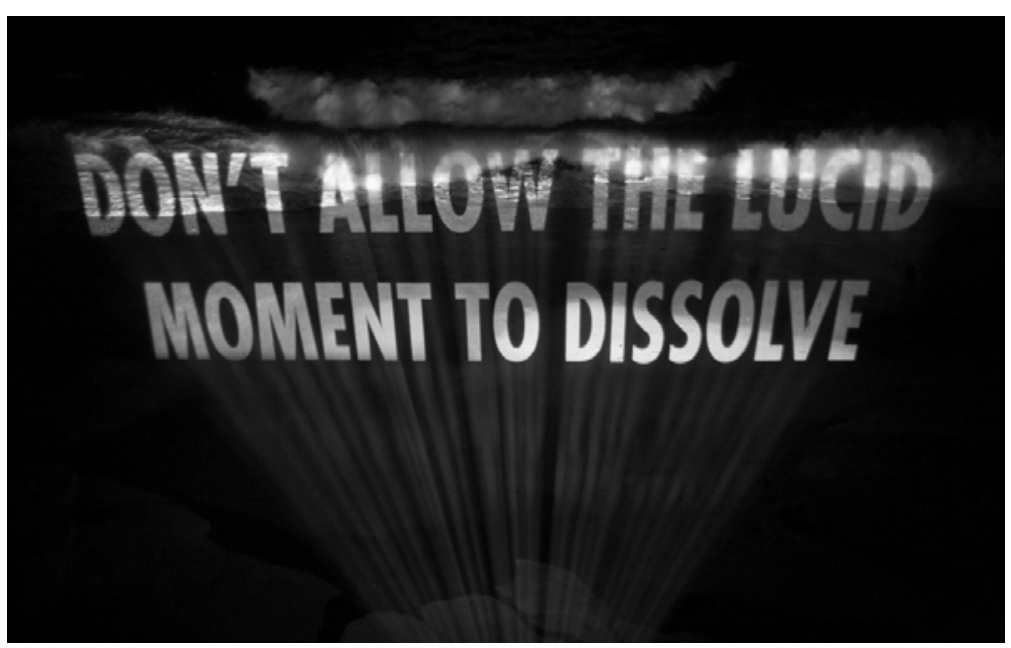

Figura 15 - Projeção em Wipeout Beach, La Jolia, California, 2007. Texto retirado de Selected Poems, Adam Zagajewski, (2002).

A mencionada avalanche midiática que compõe a geografia urbana contribui para a formação de um olhar em trânsito permanente, um olhar que se move vertiginosamente em direção a novos enunciados e novas imagens. Sobre a maneira como a aceleração crescente e contínua da vida contemporânea produz mudanças sensíveis nas formas de apreensão da paisagem, Nelson Brissac Peixoto afirma: 
"As transformações mais radicais na nossa percepção estão ligadas ao aumento da velocidade da vida contemporânea, ao aceleramento dos deslocamentos cotidianos, à rapidez com que o nosso olhar desfila sobre as coisas. Uma dimensão hoje está no centro de todos os debates teóricos, de todas as formas de criação artística: o tempo. O olhar contemporâneo não tem mais tempo." (Peixoto, 2003, p. 209)

Neste sentido, a construção de situações que possibilitam experiências estéticas capazes de desacelerar a percepção da cidade, incitando estados reflexivos, apresentam-se como estratégias benvindas de reconquista do tempo presente. As imensas projeções luminosas que Holzer inicia em 1996, as chamadas "xenon projections", que ocorrem à noite em locais emblemáticos de cidades ao redor do mundo, destacam-se neste processo. Nelas, textos feitos de luz percorrem lentamente fachadas de museus, prédios históricos, igrejas, montanhas, florestas e ondas do mar, adaptando-se ao espaço e à geografia, em um tempo ditado pela leitura.

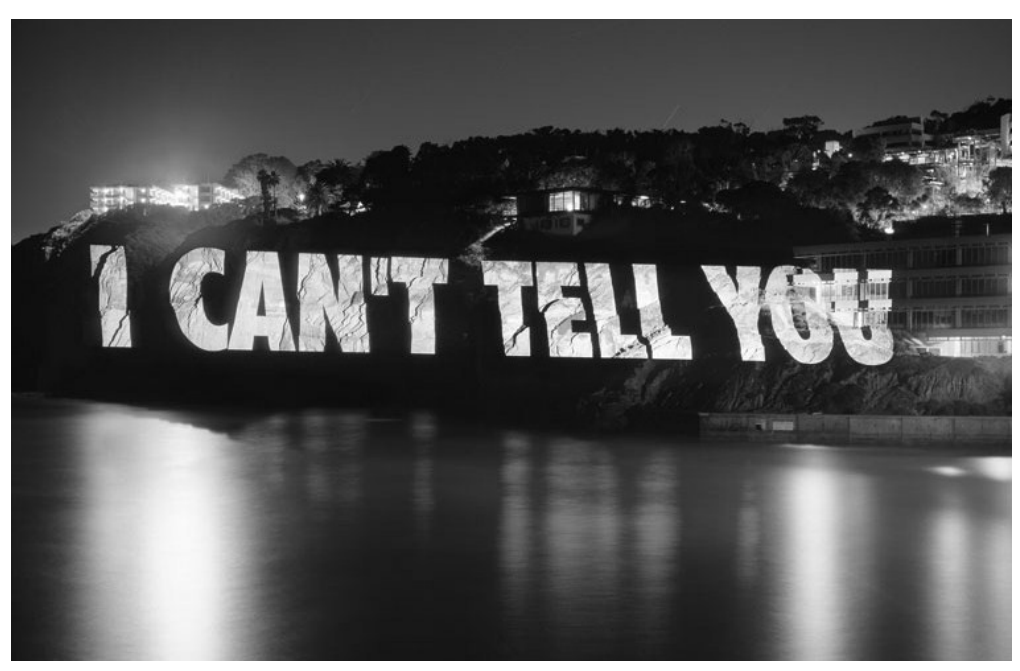

Figura 16 - Projeção no Instituto de Oceanografia, San Diego, California, 2007. Texto da série Arno (1996). 


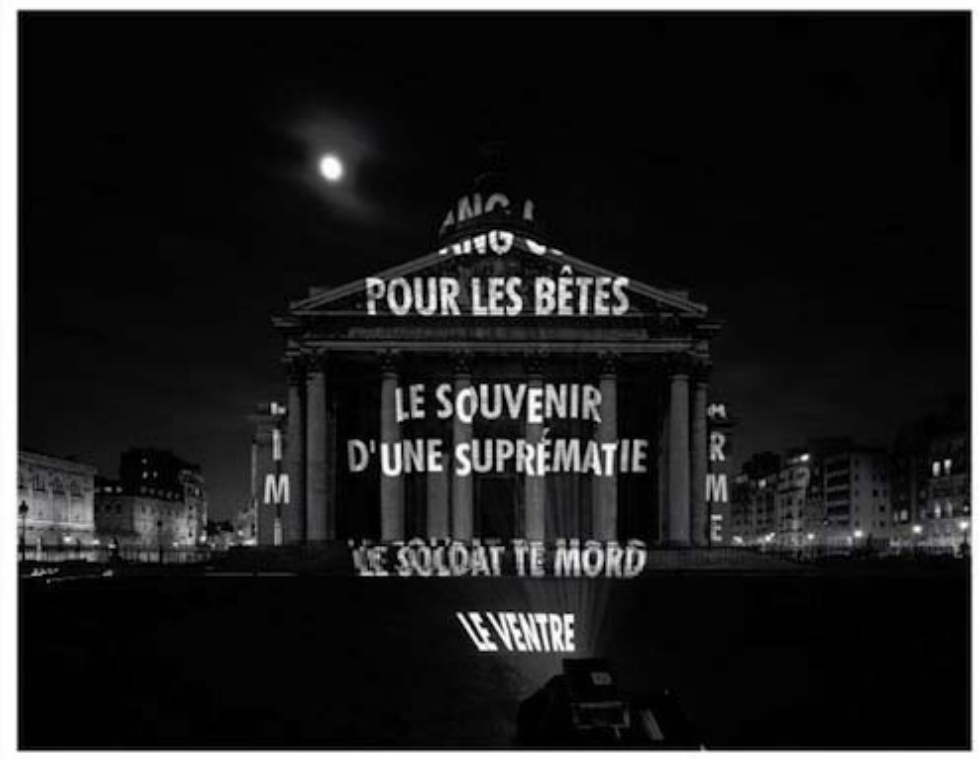

Figura 17. Jenny Holzer, Projeção no Pantheon. Paris, 2001. Texto da série Earluf (1995)

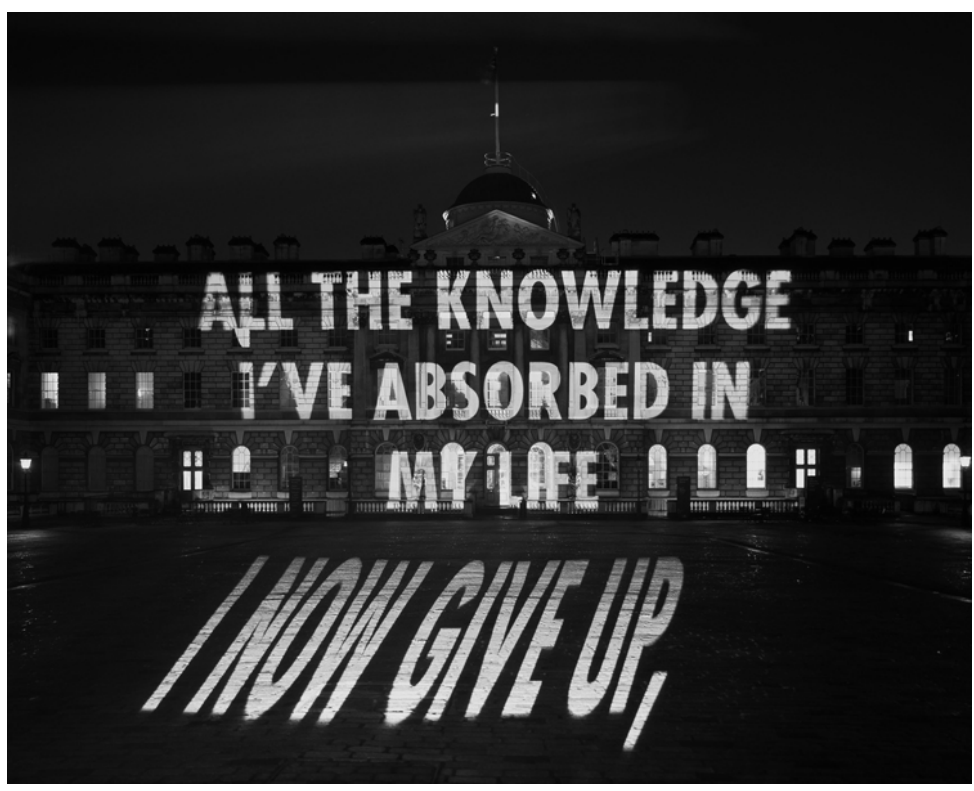

Figura 18. Jenny Holzer, Projeção na Sommerset House. Londres, 2006. Texto Song of Zion, Yehuda Amichai (1986)

Nas projeções, a cidade, espaço vivo e dinâmico, empresta um corpo às palavras, servindo-lhes de suporte, e a palavra escrita torna-se maleável ao mesmo tempo em que se investe de uma presença escultural. São vaporosas esculturas feitas de luz que após percorrerem lentamente o espaço do suporte dissolvem-se no ar da noite. É interessante notar que, na projeção de San Diego (figura 16), por exemplo, a letra, objeto bidimensional, ganha espessura ao ser projetada sobre a rocha, espaço tridimensional, invertendo a lógica da perspectiva linear, método 
através do qual a realidade espacial tridimensional é traduzida para uma superfície plana. O passante, “anestesiado” pela carga visual excessiva e veloz da cidade, é capturado pelo inusitado, uma nova imagem, fruto da interferência de algo alheio à paisagem, o texto, apresentado em uma escala que é a mesma do monumento. A monumentalidade das construções - expressões tangíveis da permanência - é contrastada à suavidade silenciosa e à efemeridade das figuras de luz. Em outro momento, Holzer, tal como o poeta John Keats, escreve na água, articulando imagens insólitas, criadoras de experiências singulares (figura 15). As projeções de xenônio pedem tempo. A duração do evento parece desacelerar o ritmo do espectador em trânsito, pois, a experiência exige que se pare para acompanhar o movimento vagaroso e a disposição dos textos. É neste sentido que podemos falar no estabelecimento de pausas semânticas no fluxo temporal do cotidiano contemporâneo e na abertura de “janelas” críticas no espaço claustrofóbico da paisagem urbana.

\section{6}

Frases lidas "pelos olhos e pelo corpo inteiro"

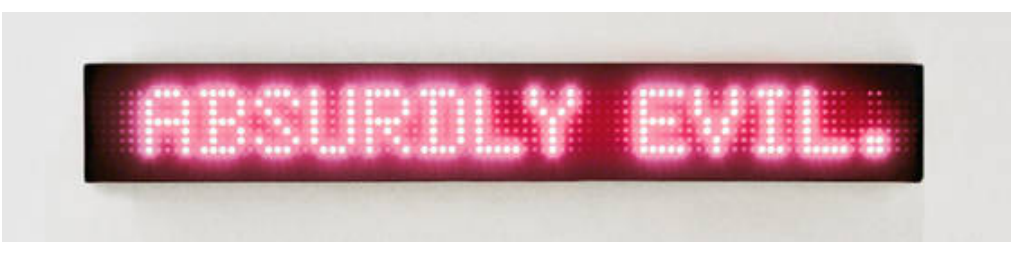

Figura 19. Jenny Holzer, série More Survival: Red Diodes, Texto: Survival (1983-85), 1985.

Em algumas instalações do início da década de 80, a exposição dos truismos incluía, além das frases escritas, um componente sonoro que consistia na gravação da leitura em voz alta dos textos. Jenny Holzer chegou a colocar, em um elevador de um prédio da Broadway, apenas o áudio contendo a gravação com a leitura das frases, apresentadas como uma espécie de música ambiente. Sobre o trabalho, ela comentou: "Eu usei o som porque ele envolve diversas partes do corpo [...]” (Joselit, 2003, p. 25). Eventualmente, o uso de áudio foi deixado de lado, mas a vontade de que seus textos fossem lidos "pelos olhos e pelo corpo 
inteiro" ${ }^{7}$ permaneceu marcante na sua obra. Os painéis eletrônicos que Holzer passa a usar com frequência a partir de 1982 permitiram-lhe não apenas alcançar um público maior, como também, e sobretudo, exercer o controle sobre o movimento da leitura. (figura 19). Neles, a palavra é moldada por uma programação que define variações na tipografia, nas cores, na velocidade, no ritmo e até no sentido percorrido pelos textos. A temporalidade da leitura perde a sua continuidade linear e torna-se fragmentada, na medida em que as palavras correm nos dois sentidos (da esquerda para a direita e da direita para a esquerda), mudam de velocidade, congelam e piscam paradas, evocando analogias com os sinais de emergência encontrados em lugares públicos. Essas modulações têm o efeito de tornar o observador consciente da natureza física do processo de leitura. Uma estratégia que parece afirmar que não basta ler, é preciso sentir que se está lendo.

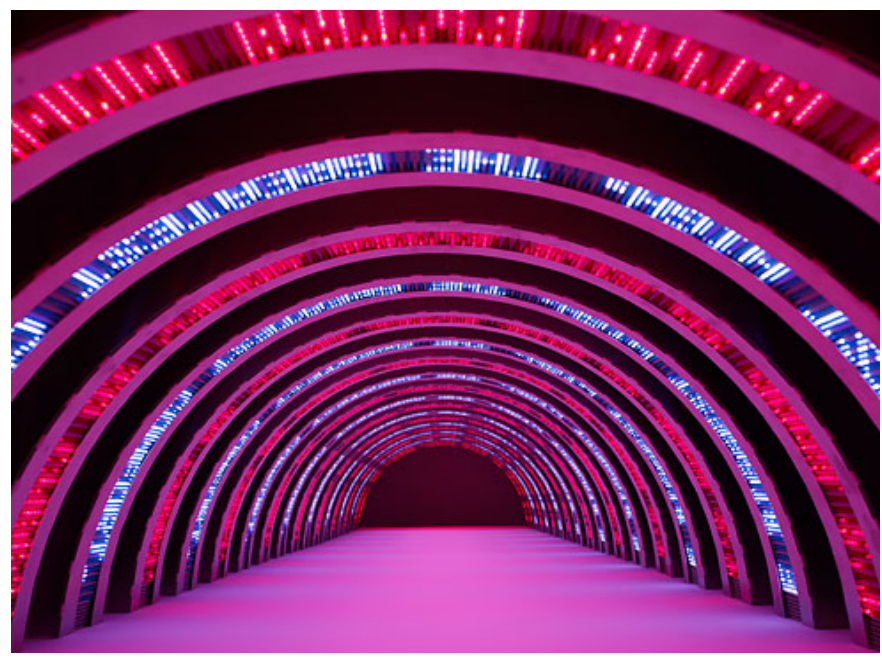

Figura 20. Jenny Holzer, “Monument” (2008), Whitney Museum, NY.

Diante das imensas “esculturas" de LED, por onde textos luminosos passam com velocidade, o observador, ora se concentra em apenas um dos sinais eletrônicos para acompanhar o movimento do seu conteúdo linguístico (e, assim, realiza a leitura dos textos), ora se deixa captar pelo efeito hipnótico do todo, onde as palavras saem de foco, transformando-se em luzes coloridas, e a leitura de cada palavra dá lugar à apreensão simultânea do conjunto (figura 20). Neste segundo

\footnotetext{
${ }^{7}$ Em entrevista concedida em 1999 no Rio de Janeiro, por ocasião da exposição no CCBB.
} 
movimento, o leitor, tornado agora um espectador, abre mão de interpretar o significado das palavras. Estas perdem a sua eloquência, a sua capacidade discursiva, e tornam-se pontos, linhas e manchas na superfície luminosa que compõe o espaço da obra. Mas esta operação não é definitiva e, com a mesma facilidade com que se tornou espectador, volta-se a ser leitor, basta que se ponha a seguir novamente a linearidade das palavras para que os pontos e linhas voltem a assumir contornos de elementos alfabéticos e a simultaneidade da forma visível dê lugar ao desenrolar sucessivo do significado. Em uma das galerias criadas para a Bienal de Veneza de 1990, na qual Jenny Holzer foi convidada para representar os Estados Unidos, 21 sinais eletrônicos horizontais apresentavam textos em verde, vermelho e amarelo, traduzidos em cinco diferentes línguas. O chão de mármore refletia as luzes dos sinais eletrônicos, duplicando o efeito desorientador provocado pela multiplicidade de padrões e tipografias que percorriam, em diferentes velocidades, o espaço dos LEDs. A atmosfera de cores e luz possui uma dimensão etérea que parece refletir a influência declarada que pintores como Mark Rothko e Henri Matisse tiveram no trabalho da artista. O impacto desta "orgia de informação" no corpo do espectador, responsável por efeitos que variavam de encantamento e hipnose até vertigens e náuseas, rendeu à sala os apelidos de “microondas” e “forno elétrico" (figura 21). É importante notar que nestas situações o corpo do leitor/espectador é enfatizado, na medida em que a leitura se dá enquanto experiência multissensorial. Essa estratégia dialoga com o conceito de uma "erótica da leitura", formulado por Susan Sontag em seu livro Contra a Interpretação (1966), no qual a autora defende uma nova sensibilidade na leitura que desenfatize a construção de sentidos através da razão em benefício da valorização dos aspectos sensuais envolvidos na experiência estética. 


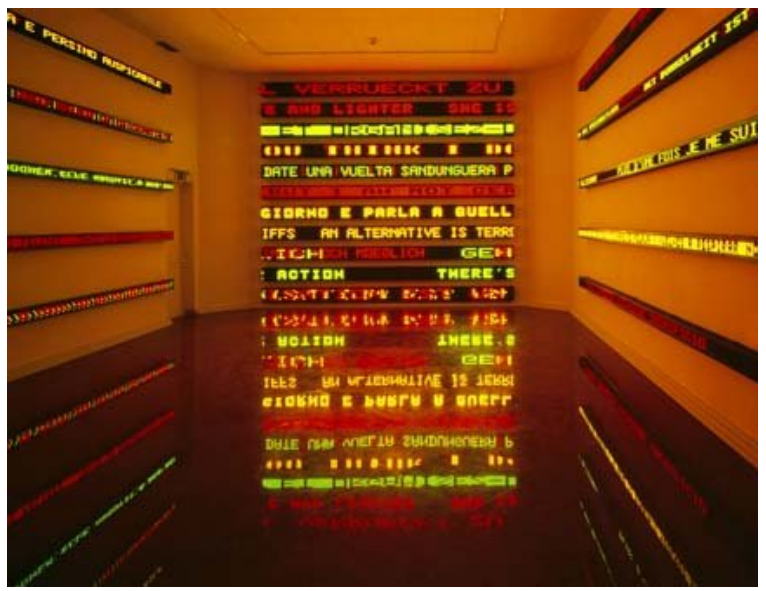

Figura 21 - Instalação, Bienal de Veneza, 1990.

Neste sentido, é válido mencionar novamente a série Under a Rock, de 1986. Embora não haja o uso de meios eletrônicos, a inscrição dos textos em bancos de pedra também enfatiza a presença do corpo do espectador. Sentando-se nos bancos - é para isso que eles se prestam, quando são situados em locais públicos - o corpo do observador bloqueia as palavras escritas. A leitura, então, exigirá uma performance, no sentido de que para ver e acompanhar o que está escrito é preciso se movimentar, se afastar, se virar e se ajeitar em cima das esculturas que são o suporte da escrita (figura 22).

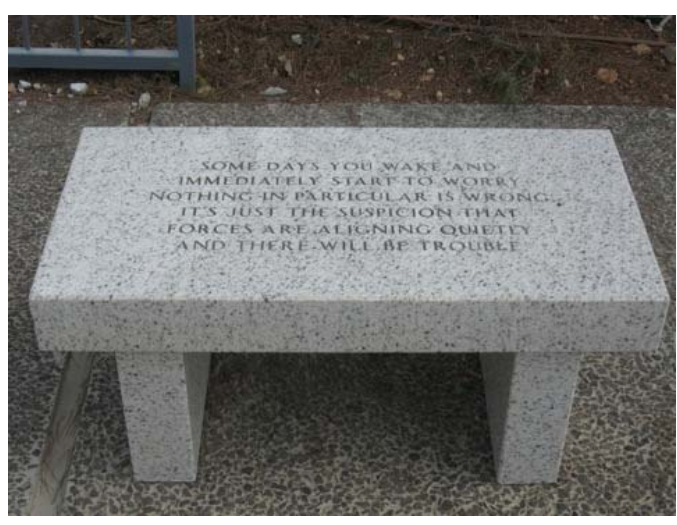

Figura 22. Jenny Holzer, série Under a Rock (1986) Bench 16. Jardim das Esculturas do Museu de Israel. 
3

\section{Lustmord - Os limites da representação}

\section{1}

\section{Suddeutsche Zeitung}
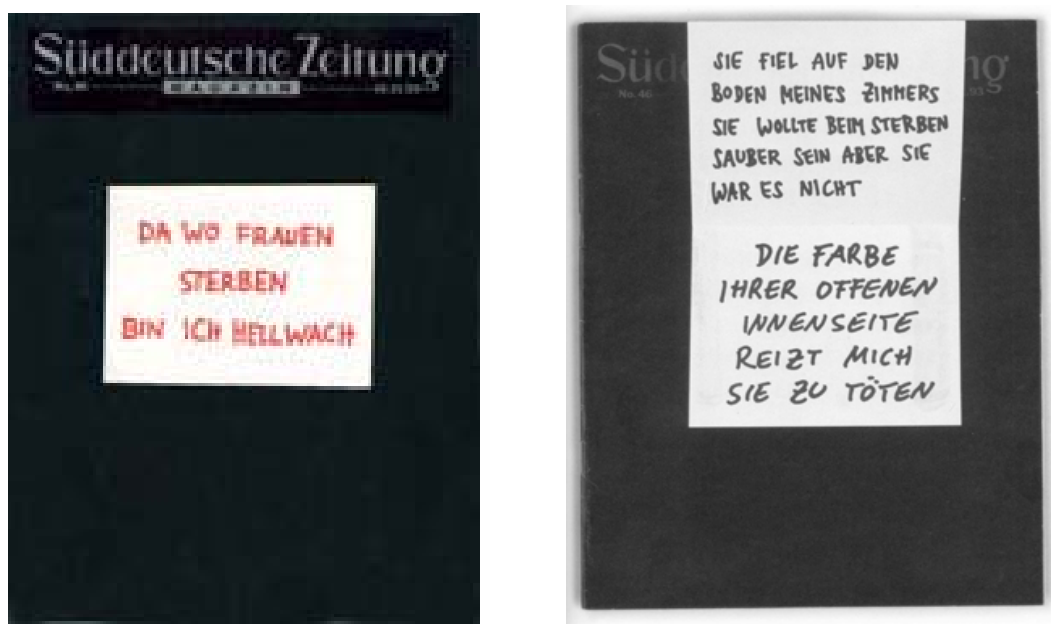

Figura 23. Capa da revista Süddeutschen Zeitung. N. 46, 11.19.1993.

Em 1992, dando continuidade a sua abordagem do tema da violência na guerra, Holzer inicou uma série de textos reunidos sob o título Lustmord. A palavra alemã "Lustmord”, que não tem correspondentes precisos no inglês ou no português, evoca imagens violentas, traduzidas pela artista como "sex-murder", “rape-slaying” ou "lust-killing”, o que, em português, poderia significar algo como "assassinato sexual”, ou "estupro seguido de morte”. A ideia inicial do trabalho surgiu a partir de uma encomenda feita pela revista semanal de um jornal de grande circulação em Munique, Alemanha, a Süddeutsche Zeitung Magazin. Lustmord foi a quarta de uma série de parcerias entre a revista e diferentes artistas visuais. A contribuição de Holzer foi publicada na edição de 19 de novembro de 1993, seguindo-se aos trabalhos de Alselm Kiefer, Francesco Clemente e Jeff Koons. O projeto consistia em um suplemento de vinte e oito páginas, inserido no interior da revista, dedicado a fotografias da artista, e mais um cartão de visitas confeccionado separadamente e afixado à capa de cada um de seus 520.000 
exemplares (figura 23). A série foi concebida em resposta à violência perpetrada às mulheres muçulmanas pelos soldados sérvios durante a guerra ocorrida na região dos Bálcãs entre 1992 e 1995. Jenny Holzer optou por não usar nenhuma fotografia ou depoimento que confirme a "realidade" dos assassinatos sexuais cometidos na Bósnia, e, neste sentido, os seus textos podem ser entendidos como "ficção". Mas ainda assim, o trabalho afirma um fato histórico conhecido, mas pouco discutido, a saber, o uso do estupro como uma arma e uma estratégia político-militar, levada a cabo sistematicamente por soldados não apenas no conflito específico da Bósnia, mas na maioria das situações de guerra de que se tem notícia. Sobre o tema a artista afirma que "na guerra o estupro é normal... faz parte da receita do soldado, é, por assim dizer, um tipo de pagamento" (Waldman, 1997, p.25). Em Lustmord, a experiência traumática de um estupro violento é recriada a partir da articulação de três perspectivas distintas: a do perpetrador da violência, a da vítima e a de um observador.

Na voz do perpetrador, o corpo violado é descrito como um meio fluido, cujos limites entre interior e exterior foram transgredidos.

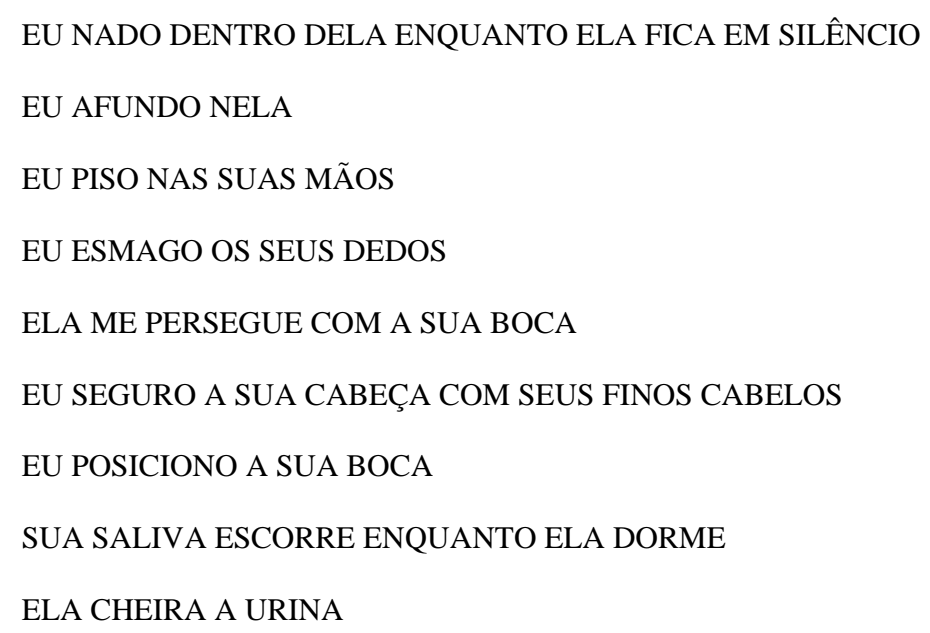

A cena do estupro é reorganizada a partir do relato da vítima que, apesar de ter seu corpo brutalmente invadido, parece tentar manter a sua integridade apontando justamente para os limites que o separam do corpo do estuprador.

\footnotetext{
${ }^{8}$ Tradução minha. Neste capítulo são citadas muitas fontes que não foram traduzidas para o português. Nestes casos, as traduções serão sempre minhas.
} 
VOCÊ ME CONFUNDE COM ALGUMA COISA QUE ESTÁ DENTRO DE VOCÊ

MEUS OLHOS ESTÃO ARDENDO PELO CONTATO COM A PALMA DA SUA MÃO

VOCÊ TEM PELE NA SUA BOCA

VOCÊ ME LAMBE ESTUPIDAMENTE

EU TENTO ME EXCITAR ENTÃO FICO MALUCA

EU NÃO GOSTO DE CAMINHAR PORQUE SINTO ISTO ENTRE AS MINHAS PERNAS

COM VOCÊ DENTRO DE MIM FICO CIENTE DA MINHA MORTE

Uma terceira voz registra a cena a partir da perspectiva de um observador, cujo desejo de ajudar é mitigado pelo temor de entrar em contato com o corpo e com os objetos da mulher. Nesta posição, a transgressão dos limites do corpo violentado pode parecer um motivo de constrangimento para a vítima.

\author{
QUANDO TUDO COMEÇOU A VAZAR DO SEU CORPO ELA CORREU PARA NÃO SER VISTA \\ EU QUERO ME DEITAR DO LADO DELA \\ EU VOU FICAR COBERTO DO QUE SAI DE DENTRO DELA \\ EU QUERO PENTEAR SEU CABELO MAS SEU CHEIRO ME FAZ ATRAVESSAR O QUARTO \\ EU SEGURO A RESPIRAÇÃO O MÁXIMO DE TEMPO POSSÍVEL \\ EU SEI QUE A DESAPONTEI \\ EU ENCONTRO AS SUAS TOALHAS ENFIADAS EM BURACOS APERTADOS \\ EU AS LEVO PARA QUEIMÁ-LAS EMBORA EU TENHA MEDO DE TOCAR NOS SEUS OBJETOS
}

Para a publicação da revista, essas palavras foram inscritas à mão com tinta preta, vermelha e azul em corpos de homens e mulheres, e fotografadas muito de perto, de forma que poros, pêlos, manchas e sardas aparecessem tão marcados quanto o texto (figura 24). Aqui, como nos outros trabalhos de Holzer, as palavras escritas não ilustram e nem explicam as imagens, elas são a própria imagem, na medida em que são tomadas também como elementos visuais. A materialidade de que se investe o corpo da escrita, bem como a linguagem gráfica, concreta, precisa, referencial e substantivada das frases têm um efeito contundente, produzindo uma fisicalidade que confirma mais uma vez o desejo de Holzer de que seus textos sejam lidos "pelos olhos e pelo corpo inteiro". As frases de Lustmord assemelham-se a fotografias por sua visualidade visceral, pelo modo 
rápido como são apreendidas e pelo impacto que causam. Além da visibilidade flagrante (são inscritos na pele e fotografados), os textos são criadores de novas visualidades, na medida em que as diferentes “vozes” parecem se esforçar para que o espectador veja o que elas lhe contam. Há, portanto, a construção de um espaço complexo e singular, resultado da articulação entre as linguagens visual e verbal, que explora os limites entre a sedução e a repulsa. A presença das imagens criadas por Holzer convida o olhar e seduz o espectador, mas, ao ser "capturado”, esse espectador é compelido a tornar-se leitor, e a construir as suas próprias imagens em diálogo com a realidade repulsiva, quase insuportável, que o texto afirma.

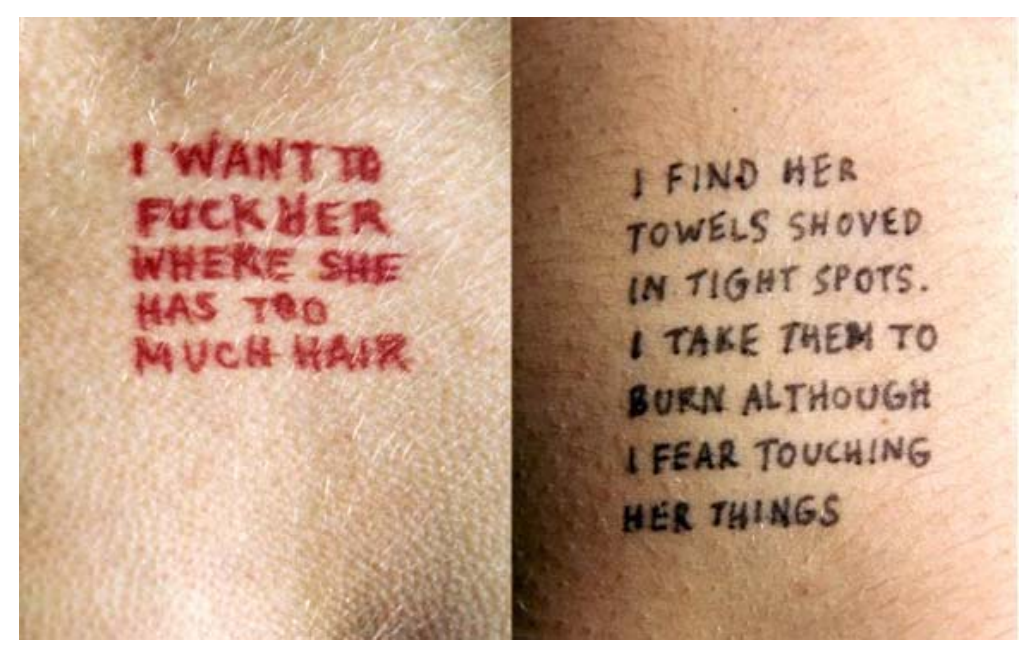

Figura 24. Projeto para Süddeutschen Zeitung. N. 46, 11.19.1993. Série Lustmord (1993-1995)

A repercussão causada por Lustmord foi enorme, principalmente considerando o espaço que as obras de arte em geral, e especialmente as obras de arte contemporânea, costumam ocupar na imprensa não especializada. Alguma polêmica já era esperada em virtude do desconforto causado pela natureza do assunto. Detalhes mórbidos de uma cena de violência sexual configuram um tema árido e incômodo, mesmo para o leitor acostumado a consumir pelo jornal notícias cada vez mais chocantes. Além disso, o uso do corpo humano, concebido como suporte para a escrita, contribuía para intensificar este efeito, pois convocava associações com tatuagens e, especialmente na Alemanha, trazia à memória as imagens das marcações nos corpos de prisioneiros dos campos de extermínio nazistas. Mas o projeto de Holzer foi publicado em 1993, na era das 
guerras já amplamente monitoradas e noticiadas por meio de videos e imagens fotográficas. Quando a Süddeutsche Zeitung Magazin chegou à casa dos leitores, a Guerra da Bósnia já tinha rendido aos jornais algumas imagens inesquecíveis, como a foto de Ron Haviv tirada na cidade de Bijeljina, na qual um miliciano sérvio uniformizado é flagrado no instante em que se prepara para chutar a cabeça de uma mulher muçulmana, morta ou quase, caída sobre a calçada entre dois outros corpos femininos, (figura 25). É possível presumir, portanto, que os leitores da revista já estivessem, em certa medida, cientes da orgia de violência promovida na Bósnia pelas forças sérvias. Além disso, as relações entre a violência cometida contra as mulheres e as estratégias militares em tempos de guerra já haviam se tornado conhecidas. Basta lembrar de eufemismos como "Joy Divsions" (“divisões da alegria”) - setores dos campos de concentração nos quais mulheres judias serviam de escravas sexuais para soldados e oficiais nazistas, ou "Comfort Women” ("mulheres de alívio”) - as milhares de mulheres coreanas sequestradas e encarceradas a serviço do exército japonês em "bordéis militares” na China. Algumas dessas mulheres sobreviveram para contar as suas histórias, e seus testemunhos foram registrados em livros, entrevistas e documentários. Em 1993, as imagens dos prisioneiros bósnios no campo de extermínio criado pelos sérvios em Omarska, norte da Bósnia, já haviam começado a ser divulgadas, e os jornalistas não demoraram para apontar a ausência quase absoluta de mulheres entre 15 e 35 anos nas fotos.

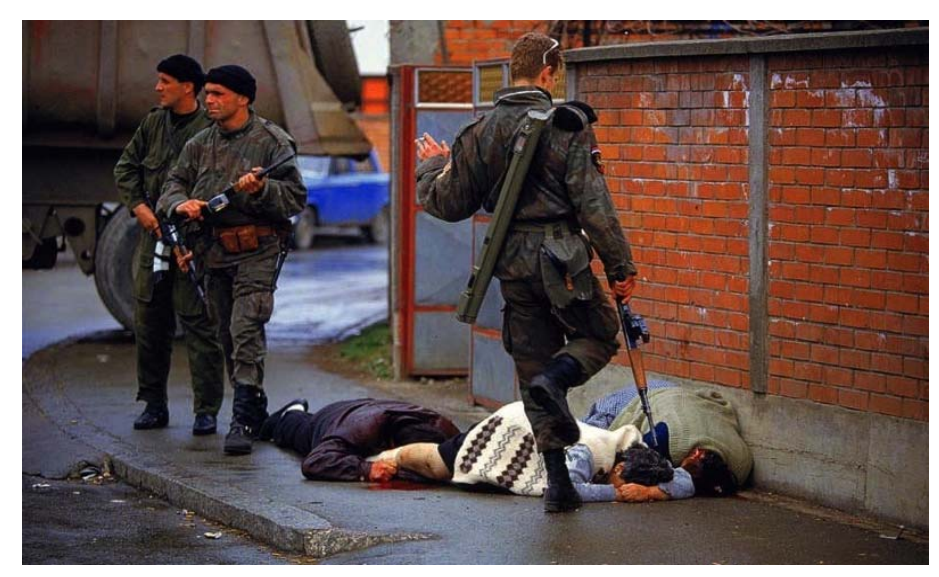

Figura 25. Foto de Hon Haviv, Bósnia, 1992. 
Mesmo assim, a obra causou "um escândalo muito maior do que se podia prever” (Simon, 1999 p.47), tendo sido objeto de debates por dias seguidos em jornais e revistas dentro e fora da Alemanha. Curiosamente, no centro das discussões não estava o conteúdo dos textos (a descrição quase pornográfica da violência sexual cometida contra a mulher) e nem o eco de memórias traumáticas evocadas pelas marcações dos corpos. O grande alvo dos debates em torno da obra foi a capa da edição, mais especificamente, o material usado para a impressão do seu texto. Na parte de dentro do cartão de visita branco afixado à capa da revista havia duas mensagens. Escrito em tinta preta, lia-se "Die farbe ihrer offenen innenseite reitz mich sie zu toten" (“a cor dela por dentro é suficiente para me fazer mata-la") e "sie fiel auf den boden meines zimmers sie wollte beim sterben sauber sein aber sie war es nicht" (Ela tentou ser limpa ao morrer mas não conseguiu. Eu vejo seu rastro”). Na parte da frente do cartão liase, em vermelho: “Da wo frauen sterben bin ich hellwach” (Estou acordada no lugar onde as mulheres morrem). Mas essas palavras não haviam sido impressas em tinta vermelha apenas como uma maneira de simbolizar o sangue derramado pelas vítimas. Elas foram impressas com sangue de verdade, doado por mulheres alemãs e iugoslavas que se voluntariaram para participar do projeto. Em Lustmord, há um resgate da origem corporal da palavra, pois, não apenas os textos são escritos à mão, o que enfatiza a escrita como gesto corporal, como também, tanto o suporte (pele), quanto a tinta (sangue) são elementos do corpo humano. O sangue doado pelas voluntárias passou por um procedimento rigoroso antes de ser utilizado, sendo submetido a testes de hepatite e HIV e, então, superaquecido para eliminar a presença de agentes infecciosos. Apenas depois de passar por todas as etapas desse processo o sangue foi misturado à tinta de impressão usada nos cartões. Ainda assim, o gesto foi responsável por uma verdadeira comoção, e Holzer foi acusada de uma série de contravenções - desde agitação política, até desperdício de sangue. A julgar pelo “convite” afixado à capa da revista, grande parte dos leitores, muitos dos quais não conheciam o trabalho da artista, esperavam encontrar nas fotografias inseridas no interior da edição imagens que ilustrassem a violência evocada pelo texto. Contudo, essas expectativas são frustradas, uma vez que as fotografias do interior da revista não trazem nenhuma imagem gráfica da situação apresentada na capa. Nelas, a figura do corpo humano é reduzida a uma região pequena e não identificável. Não é possível saber qual foi 
a parte do corpo fotografada e nem mesmo se trata-se de um corpo feminino ou masculino. Mostra-se apenas o espaço suficiente para comportar a escrita. O espaço onde-se espera-se ver imagens (retratos da vítima, do perpetrador, do local onde foi cometida a violência) é povoado por mais palavras, ao passo que essas mesmas palavras são repletas de possíveis imagens.

Considerou-se que a presença do sangue na casa dos mais de quinhentos mil leitores do suplemento semanal de um jornal popular, ainda que testado em laboratório, livre de germes, e em quantidades ínfimas, extrapolava um limite ético. O projeto foi discutido em diferentes publicações, atraindo tanto respeito - o trabalho recebeu a medalha de ouro do Clube de Diretores de Arte da Alemanha em 1994 -, quanto críticas severas, de setores que o consideraram muito visceral, muito literal, mas, sobretudo, uma ameaça à saúde daqueles que manusearam o cartão. Um tribunal regional da Alemanha chegou a sugerir o recolhimento daquela edição sob a acusação de que a revista constituiria uma "ameaça à saúde pública” (Simon, 1994, p. 82). No centro das preocupações estava o medo da transmissão de doenças, em geral, e do vírus HIV, em especial. A revista Time US de 29 de novembro de 1993, num artigo intitulado “Talk of the Streets” (assunto das ruas) afirmou que a Süddeutsche Zeitung Magazin "tentou levar a violência perpetrada às mulheres na guerra diretamente para a casa de 520.000 leitores” e que esta iniciativa havia sido considerada por muitos "sensacionalista demais". Peter Heimer, conselheiro da Cruz Vermelha alemã, foi além num pronunciamento no qual afirmou que o ato era "repulsivo e absurdo" (Simon, 1994, p. 82). Somado ao temor diante do suposto risco de contaminação, muitos leitores experimentavam a sensação de terem sido enganados, uma vez que só era possível saber da presença do sangue no cartão afixado à capa, a partir da leitura do interior da revista, ou seja, após já tê-lo manuseado. É difícil não pensar que a forma como eles reagiam à notícia de que o cartão continha sangue feminino ecoa a posição do observador de Lustmord, que teme "tocar nos objetos" que tiveram contato com a vítima da violência. Não era a crueza das palavras e nem a realidade que elas denunciavam as responsáveis pelas reações suscitadas, mas sim, o fato de o leitor, desavisado, ter entrado em contato, através das páginas “envenenadas”, com os resquícios do sangue de uma desconhecida. A informação sobre a origem das palavras tornava o jornal um hóspede perigoso e não desejado. 
A repercussão causada pelo projeto expõe questões polêmicas como o medo que se tem de sangue em geral e, especialmente, do sangue feminino, e as noções de sangue impuro, ou contaminado, noções centrais às próprias práticas de limpeza étnica empreendidas pelos soldados sérvios na guerra da Bósnia e por tantos outros militares em conflitos ao redor do mundo. Além disso, o gesto pode ser interpretado como uma acusação da responsabilidade ou da culpa das quais o espectador prefere se imaginar isento. Neste sentido, é como se o trabalho sugerisse que aqueles que consomem de forma distante e segura as imagens da guerra também tivessem “sangue nas mãos”. Mas, ainda assim, é no mínimo estranho pensar que uma única frase impressa com algumas gotas de sangue doado por mulheres voluntárias possa chocar mais do que a enorme quantidade de sangue derramada pelas milhares de mulheres inocentes, vítimas de conflitos civis e políticos. O episódio coloca, então, uma série de questões, dentre as quais, vale destacar a seguinte: de que forma a estratégia usada por Holzer para representar a violência cometida contra as mulheres na guerra pode ser mais “chocante”, mais “repulsiva” e mais "absurda” não só do que a própria realidade a que a obra se refere, mas também do que a outras incontáveis representações (muitas delas mais explícitas e mais figurativas) dessa mesma realidade? Em outras palavras, como o trabalho de Holzer consegue se impor numa cultura já saturada por representações da violência?

Um caminho possível seria afirmar que a obra de Holzer constituiu uma ameaça não tanto à saúde do espectador/leitor, mas, sobretudo ao sistema de representação em que se insere a imagem/texto. A materialidade de que se investe o corpo da escrita (sangue feminino) desestabiliza o sistema pelo qual estamos acostumados a consumir as imagens que representam um “objeto real”. Em Lustmord, o objeto (sangue) é convertido em texto e o texto, por sua vez, é convertido em imagem. Imagem e objeto, então, se confundem, e ambos são tocados não apenas pelo olhar, mas pelas próprias mãos do espectador. A distância entre o sujeito que olha, a imagem que representa e o objeto representado é, assim, suprimida, e a falsa proximidade criada pelos meios de comunicação - entre o espectador que acompanha a guerra de sua poltrona e a vítima das atrocidades noticiadas - é convertida em uma proximidade real. Neste sentido, a combinação estratégica que Holzer faz de sangue e tinta, corpo e palavra, promoveria uma reconfiguração do espaço da representação, alterando a 
lógica usual do consumo dessas imagens, lógica que costuma obedecer a uma hierarquia entre o sujeito que observa e o objeto da observação.

\section{2}

\section{A Representação do Estupro}

O estupro é um tema popular nas artes visuais, um objeto difícil de se representar, mas, ao mesmo, tempo muito representado e, sobretudo, um problema real. De acordo com a holandesa Mieke Bal, discutir as suas representações (e as interpretações dessas representações) é urgente, na medida em que elas não são apenas afirmativas de noções culturais construídas em torno da violência sexual, mas também constitutivas destas mesmas noções. Para a historiadora da arte é importante que, de uma forma geral, a teoria seja entendida como uma prática ativa na formação das condições representativas que constituem a contemporaneidade. Em Reading Rembrandt (1991), a autora discute o tema a partir de uma abordagem que se coloca além da antiga (mas ainda popular) oposição entre palavra e imagem, buscando entender as formas como a arte opera em uma determinada cultura. A sua análise investiga os efeitos complexos derivados da relação entre duas pinturas de Rembrandt, ambas intituladas Lucrécia, datadas de 1664 (figura 26) e 1666 (figura 27), e os textos de Tito Lívio e William Shakespeare, intitulados, respectivamente, História Romana e O Estupro de Lucrécia. A história é conhecida na cultura ocidental: Lucrécia é uma dama romana, bela, casta e virtuosa, casada com Lúcio Tarquínio Collatino. Enquanto seu marido viaja, Sexto Tarquínio, filho do rei de Roma, hospeda-se em sua casa, aproveitando-se da situação para violentá-la. O perpetrador ameaça, caso ela resista, matá-la e acusá-la de adultério, deixando ao seu lado o cadáver de um escravo nu e degolado. Consternada pela perda da sua honra, Lucrécia manda chamar seu pai e seu marido e, logo após obter deles um juramento de vingança, suicida-se com uma adaga no peito. Os dois homens, pai e marido de Lucrécia, partem imediatamente para buscar vingança contra o pai do perpetrador, o rei de Roma, iniciando, assim, a revolução que culmina com o fim da monarquia e a fundação da República Romana. 


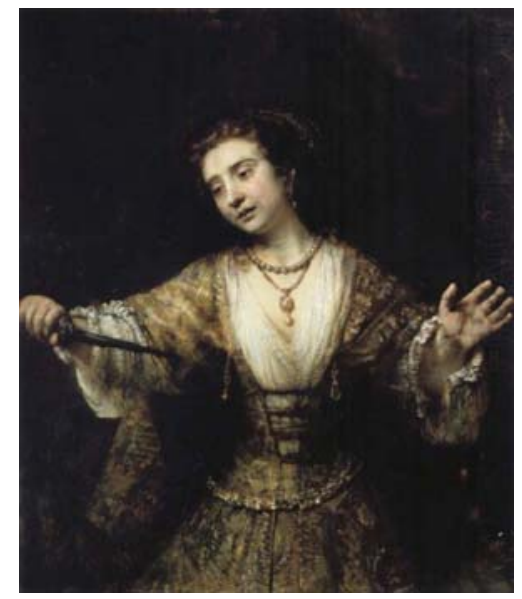

Figura 26. Lucrécia 1664, Rembrandt.

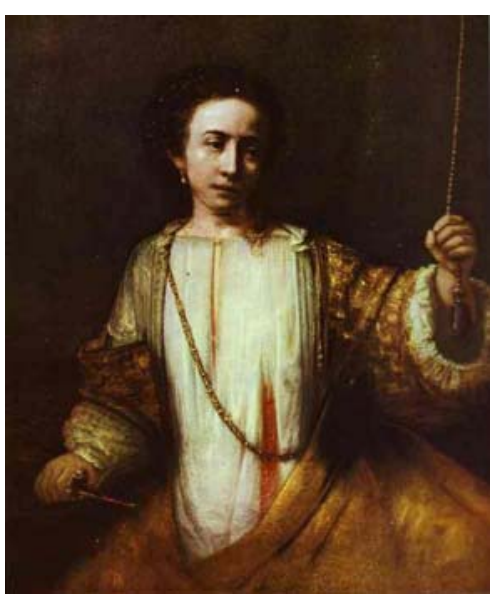

Figura 27. Lucrécia. 1666, Rembrandt.

De acordo com a autora, o mito de Lucrécia é construído com o intuito de ignorar, ou mesmo apagar, a experiência própria do estupro. Bal aponta para o silêncio que cerca o estupro, não apenas nos trabalhos analisados por ela, mas na grande maioria das obras que abordam o tema. O estupro em si, como ato ou experiência, é pouco representado na arte e esse é um dos fatores que tornam a abordagem de Lustmord singular. O que se costuma ver são muitas representações dos momentos que precedem a violência (como em algumas gravuras de Goya da série Os Desastres da Guerra) ou das consequências que a seguem (como nas Lucrécias de Rembrandt, que mostram o seu suicídio, mas não o seu estupro). Para Bal, a ênfase das pinturas no ato do suicídio, representado como a consequência lógica ou natural da violação da honra de Lucrécia, demonstra um aspecto importante que permeia a ideologia em torno do estupro, segundo a qual é 
a própria vítima que comete um crime contra si mesma. Na tela "pênis” e “adaga”, a arma do estuprador e a arma da vítima, espelham-se, e a penetração violenta de um objeto exterior e destrutivo no corpo da vítima precisa ser repetida. Na pintura de 1666, a noção de que a vítima estaria deliberadamente repetindo a violência cometida pelo perpetrador seria afirmada de forma ainda mais contundente, pois a adaga já suja de sangue que Lucrécia segura com sua mão direita é apontada para a sua vagina. Neste sentido, “o estupro é identificado com o suicídio, e não com o assassinato, como deveria ser” (Bal, 2006, p. 68). Bal defende que é esta identificação entre estupro e suicídio, mais do que a sua virtude ou castidade, que torna Lucrécia uma heroína da cultura ocidental. Este deslocamento da experiência do estupro para a metáfora do suicídio tem o efeito de promover um segundo deslocamento, o da culpa, que se distancia da figura do estuprador e se concentra na figura da vítima, corroborando um clichê cultural que infelizmente comparece até os dias de hoje - o de que a vítima é de alguma forma responsável por sua própria destruição e, portanto, deve ser novamente castigada. A vítima do estupro não pode mais viver e "é ela a primeira a concordar com isso, ela tem que ser estuprada novamente, pela adaga, pela concepção popular do estupro, por outros - polícia, oficiais de justiça, advogado do estuprador - e por si mesma” (Bal, 2006, p.72). Para Bal, é essa ideologia, da qual a história de Tito Lívio e as pinturas de Rembrandt de certa forma participam, que impede a maioria das vítimas de contar a sua experiência até mesmo, e às vezes justamente, para as pessoas mais próximas. Este silêncio, por sua vez, é o que torna a doença social do estupro tão difícil de ser curada - “Uma cultura que faz as mulheres acreditarem que elas causaram ou imaginaram o seu estupro empurra as vítimas para a autodestruição; e essa autodestruição, que completa a destruição iniciada pelo estuprador, deve demonstrar a sua vitimização” (Bal, 2006, p.76).

Na pintura de 1664 vemos Lucrécia, de frente para nós, segurando a adaga que está prestes a enfiar no próprio peito. Seu rosto virado para o lado, o movimento do seu brinco e a sua mão esquerda levantada com a palma virada para o espectador, segundo Bal, sugerem o seu constrangimento e a sua recusa em tornar-se objeto de um olhar voyeurístico. Lucrécia não quer ser vista nem por seu pai e seu marido, os espectadores implícitos da cena, e nem pelos espectadores da pintura. Esta recusa é repetida pela vítima de Lustmord, que corre "para não ser vista”, mas, ao contrário do que ocorre nas pinturas, no trabalho de Holzer o seu 
desejo parece ser “respeitado” pela ausência de imagens gráficas do corpo violado construído pelo texto. A segunda pintura de Rembrandt retrata um momento posterior ao representado no primeiro quadro, momento em que Lucrécia, já tendo se ferido, segura a adaga, agora suja de sangue, assim como o seu vestido. Na pintura de Rembrandt, é significativo que é a própria Lucrécia quem retira, após o golpe, a adaga de seu peito, e não Brutus, como ocorre na versão de Tito Lívio. Bal argumenta que este desvio operado pela pintura em relação ao texto que supostamente lhe serviu de fonte é importante, pois, ao retirar ela mesma a adaga de seu corpo, Lucrécia impede Brutus de se apropriar de seu drama pessoal para uma causa tipicamente masculina, a política. Esse paralelo traçado entre o estupro e o uso que é feito dele para fins políticos - no caso de Lucrécia, a fundação da República e em Lustmord, as estratégias de limpeza étnica - tem o mérito de ampliar o foco de abordagem usual que enquadra a violência sexual apenas a partir da figura da mulher vitimizada para situá-la em um contexto mais elaborado. Com sua mão esquerda, Lucrécia parece puxar ou apenas segurar uma corda, um elemento da pintura que já foi interpretado como parte da cortina do palco de um teatro e como a corda de um sino, com o qual Lucrécia faria um apelo aos homens presentes para que vingassem a sua desgraça. De ambas as maneiras, a corda enfatiza a presença do espectador, como testemunha, ou “observador” (para usar o termo de Jenny Holzer) da vítima que não quer ser vista, lembrando-o de que ele está ali presente e participa, de alguma forma, do que vê.

\section{3}

\section{Imagens difíceis de se olhar}

A extensa iconografia da violência que se encontra à disposição do espectador do século XXI vem de uma longa linhagem de imagens que retratam o sofrimento alheio. A dor sentida por indivíduos em tempos e terras distantes constituiu um dos temas canônicos da arte, tendo sido amplamente representada na pintura e, mais tarde, na fotografia. Com o desenvolvimento do jornalismo internacional e o avanço das técnicas fotográficas na primeira metade do século $\mathrm{XX}$, a capacidade da fotografia de caracterizar as atrocidades mais surpreendentes parece ultrapassar o poder das narrativas. A fotografia se firma em um terreno 
esvaziado pela incapacidade linguística, evocando o horror que as palavras não podiam expressar. Considerava-se que a experiência da guerra não poderia ser transmitida pelos relatos pessoais dos sobreviventes, uma vez que, diante dos horrores vividos nas trincheiras da frente ocidental, os combatentes voltavam mudos dos campos de batalha. Quando as palavras se tornam impotentes diante da dimensão dos flagelos que elas deveriam descrever, o testemunho do sobrevivente é substituído por uma imagem captada pela lente da máquina fotográfica do jornalista. Neste contexto a imagem passa a desempenhar o papel dificílimo de transmitir para aqueles que nunca vivenciaram uma guerra a realidade de regiões assoladas pelos conflitos armados. Dificílimo porque, por mais que o conteúdo ideológico presente nas imagens seja transmitido com eficácia, continua sendo impossível conhecer de fato a situação das pessoas que habitam essas imagens. É claro que a imagem fotográfica não pode ser entendida como uma transcrição objetiva do real, mas uma boa fotografia pode informar o espectador de que os problemas sociais, políticos e econômicos expostos na imagem existem “realmente”. A retórica do Realismo que caracterizava o início da Fotografia foi relativizada, pois, sabe-se que por trás do registro, há sempre um ponto de vista determinado que o torna também um testemunho individual. Além disso, hoje, as possibilidades de se manipular eletronicamente uma fotografia tornaram-se quase ilimitadas, mas essa percepção não ameaça a sua proliferação em ritmo exponencial. Nunca se produziu ou se consumiu tantas imagens e, em relação especificamente às imagens de desastres, nunca elas foram veiculadas de maneira tão ostensiva. É possível afirmar, inclusive, que, atualmente, o consumo de imagens cada vez mais dramáticas passa a constituir um traço essencial de uma cultura para qual o choque se tornou um estímulo fundamental e uma fonte de valor. O tema da violência aparece como um ponto de interseção entre diferentes manifestações da cultura visual contemporânea, como a internet, a publicidade, a televisão, o cinema e as artes visuais. Neste sentido, sobre o Brasil, Karl Erik Schollhammer afirma que "Nas últimas três décadas a violência se tornou um ponto de referência não apenas para produções da cultura de massa, como a televisão e o cinema, mas também para artistas visuais e escritores preocupados com o desafio ético e político de entender e intervir nesta realidade” (Michelsen e Schollhammer, 2011, p. 9). Como resultado desta superexposição, parece haver hoje um aumento no grau de tolerância em relação ao que é aceitável em termos 
de violência e, neste contexto, surge uma ansiedade decorrente da aparente dificuldade de distinguir entre o jornalismo comprometido e a imprensa sensacionalista ou entre a arte engajada, a cultura pop e a pornografia. Um dos exemplos mais perversos é o de um documentário filmado com o propósito de expor os crimes de guerra na Iugoslávia que passou a ser vendido por preços cada vez mais altos como vídeo pornográfico (Waldman, 1997, p. 25). As gerações mais antigas costumam assistir mortificadas à brutalidade presente nos filmes, desenhos animados, programas de televisão e jogos de videogame consumidos sem nenhum sobressalto pelos jovens hoje. E para esses jovens, nascidos na era da internet, imagens de atrocidades cometidas em lugares distantes fazem parte do cotidiano. Sobre o assunto, Susan Sontag afirma que "ser um espectador de calamidades ocorridas em outro país é uma experiência moderna essencial” (Sontag, 2011, p. 20). Questiona-se, então, até que ponto é possível dizer que esse fluxo intenso de imagens aproxima o espectador daquelas calamidades. Sobre o assunto, Julia Kristeva argumenta que os meios de comunicação de massa, apesar de chamarem a atenção do público para as atrocidades, também estabelecem uma clara distância entre este público e aqueles eventos, ao promoverem uma fascinação em torno das imagens em si (Michelsen e Schollhammer, 2011, p. 19).

Em uma cultura cada vez mais visual, é natural que a compreensão das pessoas sobre calamidades que elas não vivenciaram seja, sobretudo, um produto do impacto causado pelo fluxo contínuo das imagens (e dos discursos sobre as imagens) fornecidas pelos meios de comunicação. Assim, a consciência do sofrimento inflingido a pessoas desconhecidas, residentes em lugares remotos, passa a existir como algo construído a partir da circulação desses registros. Isso não significa, obviamente, que esses e muitos outros sofrimentos não tenham “de fato” ocorrido. O fato de martírios precisarem se transformar em espetáculo antes de se tornar "reais" para os espectadores em regiões distantes não significa que eles não tenham acontecido “realmente” naqueles lugares. A violência é, certamente, um espetáculo para aqueles que podem se dar o luxo de só conhecê-la por intermédio de imagens. Mas, nas palavras de Susan Sontag, é de “um provincianismo absurdo" universalizar o modo privilegiado pelo qual uma pequena população instruída consome as representações do sofrimento alheio (Sontag, 2003, p.92). 
Imagens difíceis de olhar, imagens que parecem punir o olhar do observador, suscitam questões a respeito da sua função. Quais são as razões (se é que elas existem) por trás da produção e da exibição dessas imagens? Há um interesse das pessoas em consumir imagens de tragédias e uma crença otimista de que talvez o impacto causado por elas tenha o poder de criar consensos. Neste sentido, a empatia provocada por imagens que retratam nitidamente a dor do outro poderia promover uma união dos espectadores em torno de sentimentos de compaixão e sofrimento ou de repugnância e revolta diante dos eventos responsáveis por causar essa dor. De acordo com esta lógica, a exposição de uma situação horrorosa promoveria a consciência daquela realidade, que por sua vez promoveria o desejo de alterá-la. Nas palavras de Rancière, esta forma de usar uma imagem “intolerável” pressuporia uma linha direta traçada entre “representação, conhecimento e ação" (Rancière, 2009, p.103). Exemplar neste sentido é a declaração do fotógrafo Alexander Gardner, um dos responsáveis por documentar visualmente a Guerra Civil Americana, que diante das fotografias que retratavam soldados confederados gravemente feridos, declarou: “aqui estão os detalhes pavorosos! Que sirvam para impedir que outra calamidade como esta desabe sobre a nação” (Sontag, 2003, p. 46).

O costume de representar o horror da guerra, em oposição à sua glória e pompa, é relativamente recente. O tema específico do sofrimento de uma população civil vítima da selvageria de um exército vitorioso populariza-se no século XVII, quando pintores e desenhistas passam a representar as então crescentes reorganizações do poder político. Um exemplo célebre do gênero são as dezoito lâminas do gravurista francês Jacques Callot que retratam a violência cometida contra civis huguenotes pelas tropas francesas do Rei Luiz XIV na invasão de Lorraine. Reunidas sob o título de "Les misères et les malheurs de la guerre” (As misérias e os infortúnios da guerra,1633), as pequenas gravuras retratam desde os combates até os estupros, a tortura e a execução dos civis. Francisco Goya y Lucientes, citado por Jenny Holzer em diversas ocasiões como uma de suas maiores influências, é provavelmente o pintor em cujo trabalho a representação dos horrores da guerra ganhou sua forma mais contundente. A série de gravuras em água-forte intitulada Los desastres da guerra (As desgraças da guerra), produzida entre 1810 e 1820, retrata os excessos da orgia de violência promovida durante a invasão da Espanha pelo exército de Napoleão, em 1808. Em 
relação ao seu poder documental, As desgraças podem ser consideradas um prenúncio da reportagem visual de guerra, mas no lugar das tradicionais legendas que viriam acompanhar esse tipo de imagem um século mais tarde, cada lâmina de Goya traz um breve texto, um comentário provocador que a torna mais dramática e mais comovedora - "No se puede mirar" (Não se pode olhar), "Esto es malo" (Isto é ruim), “Esto es peor” (Isto é pior), “Por qué?” (Por quê?). Nas gravuras de Goya, o produto da associação entre texto e imagem constitui um ataque à sensibilidade de quem as olha. Susan Sontag afirma que "as crueldades horripilantes em 'As desgraças da guerra' têm o intuito de abalar, chocar, ferir o espectador” (Sontag, 2003, p. 40). Ainda Sontag: “enquanto a imagem, como toda a imagem, é um convite ao olhar, a legenda, na maioria das vezes, insiste na dificuldade exatamente de olhar" (Sontag, 2003, p. 41). As desgraças criam uma forma singular de jornalismo pictórico, na medida em que se afirmam enquanto um ato de testemunho. Mesmo sabendo-se que nem tudo (ou talvez apenas muito pouco) do que é representado em As desgraças foi observado diretamente pelo pintor, elas criam uma espécie de ilusão “a serviço da verdade”, o que mais tarde viria a constituir um traço fundamental da fotografia. Esta ilusão é explicitada, por exemplo, quando o pintor escreve "Yo lo vi” (Eu vi isto) na legenda da lâmina 44, que retrata os habitantes de uma vila rural fugindo da invasão dos soldados franceses, uma mulher carregando um bebê em um dos braços e com o outro puxando uma criança que olha aterrorizada para trás, enquanto o padre da aldeia corre agarrado a um saco de dinheiro. Goya não deixa de registrar a violência impetrada à mulher durante a guerra. Na lâmina 9, cuja legenda é “No quieren" (Elas não querem) um soldado luta para estuprar uma jovem que resiste tentando arranhar seu rosto, enquanto uma mulher mais velha se aproxima furiosa pronta para esfaqueá-lo por trás (Figura 28). Na lâmina seguinte intitulada “Tampouco” (Tampouco), três soldados franceses deixam de lado as suas espadas e tentam dominar as mulheres que lutam deitadas no chão. Na sequência, a lâmina 11 retrata a cena que provavelmente é a mais comovente das três. Intitulada “ $\mathrm{Ni}$ por ésas” (Nem essas) a gravura mostra um soldado agarrando uma moça cujas mãos estão unidas numa súplica inútil e outro arrastando uma mulher, cujo filho, um bebê, nu, chora caído no chão (Figura 29). Embora essas três lâminas retratem algumas das crueldades mais degradantes cometidas pelo exército francês, há uma ambivalência no ciclo de gravuras que impede que elas sejam vistas como um 
panfleto pró-Espanha, no qual sádicos assassinos são opostos a vítimas indefesas. O registro que Goya fez da guerra escapa à polarização simplista que glorificaria os atos da resistência espanhola em detrimento das barbaridades cometidas pelos soldados franceses. A gravura 28, “Populacho” (Ralé) retrata um homem deitado de bruços no chão, já morto ou quase, após ter sido arrastado por uma corda que ainda está amarrada em volta de seus tornozelos. Enquanto uma mulher do povo o ataca com um cajado, seu companheiro, um camponês (ambos espanhóis), prepara-se para lhe enfiar no ânus uma vara comprida de madeira com uma lâmina afiada na ponta, usada para cortar tendões de touros. Portanto, é possível afirmar que o que aparece em primeiro plano em As desgraças, não é nem a perversidade dos invasores e nem a valentia dos guerrilheiros (esses papéis se invertem, já que os espanhóis são também retratados como extremamente perversos em algumas gravuras), mas a própria natureza da guerra, despida da nobreza cavalheiresca que a adornava. Um bom exemplo é a lâmina 12, "Para eso habéis nacido"(Vocês nasceram para isso) que mostra um homem que, tomado pela náusea diante do que vê (as consequências da guerra), vomita sobre uma pilha de cadáveres. As cenas macabras de Goya funcionam como uma espécie de manifesto anti-guerra, na medida em que apregoam a mensagem de que não há nada de nobre na guerra, de que apenas aqueles que nunca ouviram os gritos, ou viram os feridos de perto, podem acreditar na ilusão de sua glória.

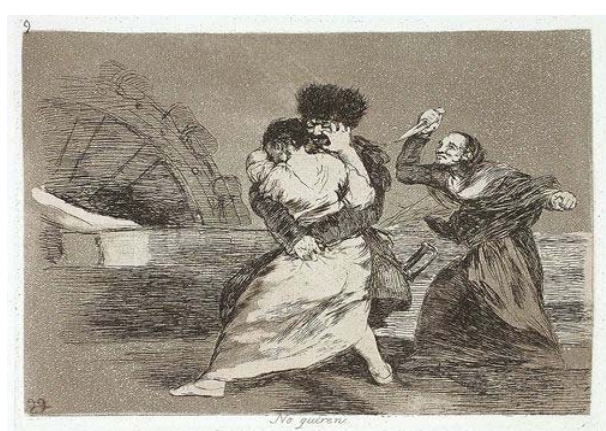

Figura 28. Lâmina 9. “No quieren”. Los Desastres da Guerra, Goya. 


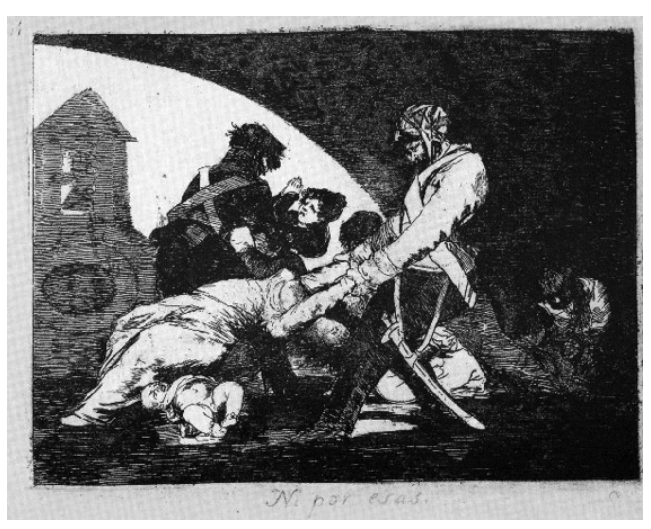

Figura 29. Lâmina 11. “Ni por ésas”. Los Desastres da Guerra, Goya.

Nas últimas décadas, muitas foram as tentativas de levar a realidade dos campos de batalha para dentro da casa daqueles que não estavam diretamente envolvidos nos conflitos. Havia artistas comprometidos, sobretudo, a opor a triste realidade da guerra à felicidade artificialmente forjada pelos anúncios e propagandas que ocupavam um espaço cada vez maior nos meios de comunicação. A série Bringing the War Home ("trazendo a guerra para casa”) de Martha Rosler é exemplar neste sentido. As colagens de Rosler contrapõem a triste realidade da Guerra do Vietnam à euforia das aparências criadas pela sociedade de consumo americana. Em uma das colagens, intitulada Baloons (1962-72), a imagem de um homem vietnamita segurando nos braços uma criança morta pelo exército americano é colada em meio à fotografia de um apartamento espaçoso e bem decorado, com balões coloridos ao fundo (Figura 30). Do ponto de vista da forma, a sobreposição de duas imagens fotográficas incompatíveis chama atenção para a própria natureza da representação, contribuindo para problematizar a ideia de "realidade” que, em maior ou menor grau, costuma-se atribuir à fotografia. A colagem de Rosler acentua a heterogeneidade dos elementos reunidos - a criança morta pode ser justaposta, mas não pode ser integrada à suposta felicidade colorida da vida doméstica nos Estados Unidos. A articulação desses elementos foi a maneira encontrada pela artista para tentar “jogar na cara" do espectador justamente a realidade intolerável que as aparências criadas pelo estilo de vida americano se esforçam tanto para encobrir. "A imagem da criança morta deveria destruir a imagem da felicidade artificial da existência americana” (Rancière, 2009, p. 85). Mas além de evidenciar a heterogeneidade dos elementos que compõem a colagem, a composição de Rosler 
chama atenção para o fato de que imagens da violência e retratos da dor alheia não deixam de ser, assim como o apartamento, os móveis e os balões, objetos de consumo. O trabalho, então, expõe realidades antagônicas ao mesmo tempo em que evidencia ligações ocultas entre estes mundos, em princípio, incompatíveis.

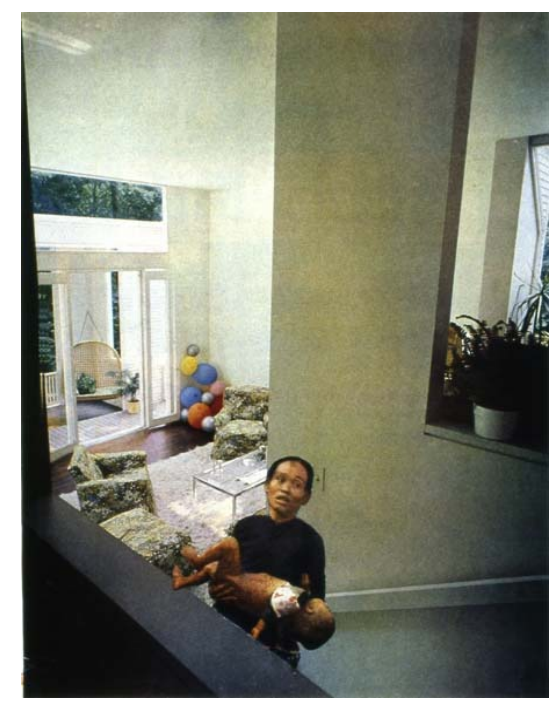

Figura 30 - Balloons, Martha Rosler da serie Bringing the war home 1967-72.

Mas será que alguma imagem tem o poder de mobilizar um espectador a opor-se a uma injustiça de forma atuante? Num cenário ideal, trabalhos como os de Goya, que reproduzem com nitidez os detalhes mais monstruosos e degradantes da guerra e, principalmente os de Rosler, que tentam estabelecer uma relação entre o sofrimento das vítimas e o conforto dos observadores, seriam capazes de sensibilizar o espectador a ponto de fazer com que ele se voltasse contra aquela situação. Uma das fragilidades desse pensamento, no entanto, é que ele pressupõe que todos os espectadores compartilhem a mesma reação diante da cena que retrata uma violência, quando, na verdade, sabe-se que imagens de atrocidades podem suscitar reações distintas - compaixão, raiva, indignação, uma manifestação em favor da paz, um desejo de vingança ou a mera satisfação de constatar que aquela barbaridade "não está acontecendo com você". Representações da violência podem provocar (e muitas vezes provocam) apenas medo, um medo vago, sem objeto determinado, capaz de levar o espectador a simpatizar com regimes mais autoritários que levantem a bandeira do controle e da segurança. Além disso, o conceito de justiça é, evidentemente, subjetivo, e a 
violência infligida a alguém pode ser considerada injusta, justa, ou até mesmo desejável, dependendo de quem é o perpetrador e de quem é a vítima. Em última instância, o que definirá se a atitude violenta observada constitui um ato selvagem de vandalismo ou um ato heroico de patriotismo será o espectador, com a ajuda dos “especialistas” que “decifram” as imagens veiculadas pelos meios de comunicação que transmitem o conflito. Um fato ocorrido há pouco tempo no Rio de Janeiro pode ilustrar bem a diferença de reações que um ato de violência amplamente noticiado pode provocar no público que o acompanha. Em novembro de 2010, o Bope, com apoio da Marinha, invadiu a Vila Cruzeiro, na Penha, numa operação intensamente monitorada pelos meios de comunicação locais. Em meio ao espetáculo criado pela imprensa, a cena do helicóptero abatendo traficantes que fugiam por uma estrada de terra ganhou destaque, sendo transmitida ao vivo e, mais tarde, retransmitida exaustivamente por emissoras de televisão locais e internacionais. A cena registrada pelo helicóptero da Rede Globo foi considerada por muitos um símbolo da vitória do "povo" na "guerra” contra o crime organizado, ainda que não se possa saber ao certo quem nesse caso é o "povo” (os moradores da Vila Cruzeiro? os espectadores da Globonews?) ou mesmo se existe a referida "guerra".

Não se pode definir a priori o efeito provocado por uma imagem. Nada garante que uma imagem terá o poder de despertar no espectador o desejo de se tornar um ator na luta contra uma injustiça e, menos ainda, de que esse desejo vá de fato ser traduzido em ação. Os detalhes mais pavorosos, mais obscenos e desnecessários já foram capturados pelas lentes de aumento dos fotógrafos e, nem por isso, pode-se dizer que o mundo se tornou um lugar menos violento. O eco sem paralelo do extermínio nazista, vastamente representado na fotografia, no cinema, nas artes visuais e na literatura até os dias de hoje, com o intuito declarado de assegurar que as atrocidades cometidas contra o povo judeu permaneçam presentes na consciência das pessoas não foi suficiente para prevenir as recentes manifestações neonazistas que têm sobressaltado o governo alemão. Há quem, inclusive, defenda uma lógica inversa, ou seja, a de que a exposição cotidiana e ostensiva ao sofrimento alheio, ao invés de mobilizar eticamente o espectador, acabe sendo responsável por uma "anestesia moral” que o torna mais insensível à dor do outro. Novamente nas palavras de Sontag, "alguém que se sinta sempre surpreso com a existência de fatos degradantes, alguém que 
continue a sentir-se decepcionado (e até incrédulo) diante de provas daquilo que os seres humanos são capazes de infligir, em matéria de horrores e crueldades a sangue-frio, contra outros seres humanos, ainda não alcançou a idade adulta em termos morais e psicológicos” (Sontag, 2003, p. 95). A autora argumenta que a representação de um sofrimento aviltante pode apenas confirmar para o observador indireto que o impulso de violência é tão essencial à natureza humana quanto os impulsos de piedade, compaixão e misericórdia. Ela pode servir somente para corroborar a noção de que coisas terríveis acontecem, principalmente, se estes sofrimentos são registrados nas regiões mais pobres do mundo. A crença na inevitabilidade da ocorrência de tragédias nestes locais é capaz de oferecer ao espectador certo conforto, já que, ao tornar inútil qualquer iniciativa, o dispensa de reagir. Se uma determinada situação lhe parecer insolúvel, se não houver nada que se possa fazer contra ela, o estado de ânimo inicialmente suscitado tende a definhar mais rapidamente. Não raro, diante de uma imagem que retrata uma realidade completamente inassimilável, a reação do espectador acaba sendo traduzida em uma acusação contra a própria imagem, evidenciando as ambiguidades de uma cultura que condena imagens mais radicais ao mesmo tempo em que as solicita constantemente. A incapacidade de lidar com o horror causado por uma foto, por exemplo, pode fazer com que o espectador se volte, não contra a realidade que esta foto expõe, mas contra o próprio ato da representação. Essas imagens podem operar uma transferência - deixa-se de questionar o que está na imagem e passa-se a questionar a imagem em si ou o ato de produzir e exibir este tipo de imagem. Neste caso, as questões colocadas pela representação deixam de ser a respeito da sua função e passam a girar em torno da sua legitimidade. É aceitável produzir e exibir este tipo de imagem?

\section{4}

\section{A representação sob a ótica da legitimidade}

A reação provocada pela fotografia emblemática tirada no Sudão pelo fotógrafo sul-africano Kevin Carter pode ser pensada como um exemplo da situação em que o questionamento da imagem em si ou do ato de produzir e exibir a imagem suplanta o questionamento do que está representado na imagem. A foto da criança esquelética e exausta rastejando no chão enquanto um abutre espera a 
sua morte rendeu ao fotógrafo um Prêmio Pulitzer, mas também lhe rendeu as acusações mais perversas - Quem seria o verdadeiro abutre? Quem estaria esperando de forma sórdida a morte de sua presa? A imagem paralisa um momento decisivo - o momento em que a menina estava prestes a morrer, mas que talvez ainda fosse possível fazer alguma coisa para salvá-la. Mas enquanto o espectador contempla a foto, constata que o que quer que estivesse prestes a acontecer, na verdade, já havia acontecido. Ele, então, experimenta a "vertigem do tempo esmagado" de que fala Roland Barthes, a constatação vertiginosa de que concomitantemente "isto será" e "isto foi” (Barthes, 1984, p. 144). Talvez tenha sido este sentimento de impotência experimentado pelo espectador a causa do ataque indignado contra o ato e o autor da representação. Imputou-se ao fotógrafo a obrigação de ter ajudado a menina, pois arriscar a sua vida no deserto sudanês para dar visibilidade a miséria daquela população, embora já fosse muito mais do que consumi-la passivamente pelos jornais, ainda era considerado insuficiente. $\mathrm{O}$ espectador condena no fotógrafo as faltas que conhecem bem. Ficar indiferente à situação da menina, não ajudá-la, assistir sentado e impassível à sua desgraça era inaceitável. Evidente que é difícil ignorar o elemento de “exploração” presente em fotos como a tirada por Carter. Mieke Bal afirma que a fotografia, mais do que qualquer outra forma de arte, nos confronta com a injustiça econômica de uma troca na qual "o sujeito é exposto, às vezes nos momentos mais íntimos e dolorosos, enquanto o fotógrafo embolsa o dinheiro que o espectador está disposto a pagar" (Reindhart, Edwards, Duganne, 2007, p. 95). Sabe-se que uma foto objetifica, transforma uma pessoa ou uma situação em algo que se pode possuir e dispor e isto, sozinho, é motivo para torná-la alvo de reflexões. Além da exploração, acusa-se fotos como esta de promoverem uma dupla exposição ou uma revitimização do sujeito objeto da imagem. Neste sentido, ao exibi-lo na situação degradante em que ele foi capturado, o fotógrafo estaria prolongando o seu constrangimento, violando novamente a sua dignidade e, de certa, maneira repetindo uma situação que teoricamente ele se propôs a denunciar. Mas, dito tudo isso, é necessário, sob pena de se cometer uma injustiça, tentar ver a questão de um ângulo diverso. É isto que faz o artista chileno Alfredo Jaar, em uma instalação intitulada The Sound of Silence (1995) que reconstrói com palavras, em silêncio, a trajetória de Kevin Carter, sua luta contra o Apartheid, sua viagem ao Sudão, até o momento do registro daquele espetáculo macabro e da consequente 
campanha que, afirma-se, levou Carter ao suicídio. Até o momento em que presenciou aquela cena, Carter "não havia sido um simples espectador, mas um ator engajado na luta contra o Apartheid no seu país”. Ao final da balada silenciosa de oito minutos criada por Jaar, a célebre fotografia tirada por Carter aparece por um instante de segundo apenas, sugerindo que a questão talvez não devesse girar em torno da necessidade ou não de mostrar os horrores sofridos pelas vítimas de uma violência específica, mas sim em torno da configuração do sistema sensível em que elas são recebidas. A questão “deveria girar em torno da construção da vítima como um elemento em uma certa distribuição do visível" (Ranciére, 2009-A, p. 99 e 100). Rancière afirma que os massacres são tolerados, não porque faltam imagens, mas porque essas imagens enquadram vítimas anônimas, pessoas sem nomes, sem histórias, incluídas em uma lógica que atribui às massas a representação visual e torna a linguagem verbal o privilégio de poucos.

Outra questão que costuma aparecer com frequência nas discussões sobre a representação do sofrimento é aquela relacionada à “estetização da imagem”. Arthur C. Danto, no livro The Abuse of Beauty (2003), em que se propõe a investigar a trajetória percorrida pela "beleza” nas artes visuais do século passado, chama a atenção para a noção amplamente divulgada na cultura contemporânea de que "de certa forma, a beleza trivializa o objeto que a possui” (Danto, 2006, p. 27). Existe uma ansiedade principalmente em relação às fotografias que utilizam a técnica para compor imagens belas da desgraça ou da miséria humana. Considerase irresponsável, ou mesmo indecente, transformar a dor do outro em algo exuberante, elegante ou bem composto do ponto de vista da forma. Isto porque, belas representações são acusadas de tornar palatáveis conteúdos horrorosos, de desviarem a atenção do tema retratado dirigindo-a para o próprio meio. As representações que promovem a estetização de temas como a violência, a guerra ou a fome, teriam a capacidade de distrair e, pior do que isso, até mesmo dar prazer ao espectador que contempla a dor do outro - "embelezar é uma das operações clássicas da câmera e tende a empalidecer qualquer reação moral àquilo que a câmera mostra” (Sontag, 2003, p. 69). Assim, em relação a temas consternadores, parece haver um privilégio de imagens que buscam reduzir (ainda que de forma consciente) a subjetividade do criador a um mínimo possível. Quanto menos elaboradas em termos artísticos, quanto mais elas se assemelharem 
a fotos amadoras, maior o grau de credibilidade e autenticidade atribuído a elas. A obra de Sebastião Salgado, que expõe a situação extrema em que vive parte da população mundial, acabou tornando-se um dos principais alvos da campanha que condena a procura de uma estética em um contexto de miséria. Mas a estetização da imagem pode servir a diferentes propósitos, entre os quais estão a capacidade de questionar ou desnaturalizar a representação, e o poder de intensificar (e não de mitigar ou neutralizar) os efeitos decorrentes da imagem. Em um sentido diverso daquele que enxerga com reservas as imagens belas, é possível pensar que talvez os efeitos sensuais provocados por uma fotografia bem elaborada do ponto de vista formal possam aumentar o envolvimento do espectador com o tema da imagem e, assim, incitá-lo a refletir não apenas sobre o objeto retratado, mas também sobre o próprio ato de contemplá-lo, sobre a natureza da relação estabelecida entre o sujeito que olha e objeto do olhar.

A questão de como mostrar o sofrimento alheio (é legítimo produzir imagens belas ou bem compostas?) é acompanhada da questão não menos polêmica de quanto mostrar do sofrimento alheio. O que (ou o quanto) se pode mostrar? Como não há regras explícitas acerca do quanto os meios de comunicação podem mostrar ao público, uma série decisões tomadas diariamente pelos editores de fotografia dos meios de comunicação em massa ao redor do mundo vai abrindo novos precedentes que ajudam a consolidar um relativo e temporário consenso acerca desses limites. É curioso pensar que, em uma cultura onde o “mau gosto” é defendido como um valor (vide a popularidade de manifestações que privilegiam a estética do kitsch, do trash e do deliberadamente tosco) muitas dessas decisões são norteadas por um pseudo critério de "bom gosto”, um termo que parece ter sido esvaziado de sentido. Sobre o tema, Giorgio Agamben comenta que a constante relativização do que é bom gosto e mau gosto na arte tornou essa distinção impossível (Agamben, 1999, p. 26). Entretanto, foi esse o limite alegado para a não publicação de imagens dos mortos no atentado contra o World Trade Center em 11 de setembro de 2001. É possível perceber que o quanto se pode mostrar é determinado, de certa maneira, em função da proximidade entre a vítima (objeto da foto) e o espectador que consome as imagens. Portanto, a legitimidade da fotografia, ou a falta dela, diz respeito, não tanto a um critério de "bom gosto”, mas a uma adequação entre a identidade da vítima e o grau de exposição que pode ser atribuído a ela - “Quanto mais remoto 
ou exótico o lugar, maior a probabilidade de termos imagens frontais completas dos mortos e dos agonizantes” (Sontag, 2003, p. 61). É por isso que temos tantas imagens perturbadoras e inesquecíveis do continente africano, imagens de rostos feridos e corpos mutilados, imagens em que a população aparece padecendo de toda sorte de desgraças, desde a fome até a AIDS. Sontag vê nesta praxe jornalística resquícios do "costume secular de exibir seres humanos exóticos”, costume que permitiu que até o início do século XX indivíduos de países colonizados fossem mostrados, tais como animais de zoológico, em exposições montadas nas capitais europeias (Sontag, 2003, p. 62). Em contrapartida, nas fotografias publicadas em que soldados americanos aparecem mortos eles estão, em geral, de bruços ou cobertos - “com relação aos nossos mortos, sempre vigorou uma proibição enérgica contra mostrar o rosto descoberto" (Sontag, 2003, p. 61). Sobre o assunto, Mark Reinhardt menciona um estudo do Los Angeles Times que conclui que entre 11 de setembro de 2004 e 28 de fevereiro de 2005 nenhum jornal ou revista americana de grande circulação (Los Angeles Times, The New York Times, The Washington Post, Times e Newsweek) publicou uma única foto de soldados americanos mortos. Quando eram publicadas matérias de soldados mortos em combate, estas eram ilustradas com fotos de sua família em luto (Reindhart, Edwards, Duganne, 2007, p. 18).

Ainda em relação à questão da legitimidade (ou da ilegitimidade) de uma representação, pode-se condenar uma imagem sob o argumento de que a realidade que ela se propõe a representar é em si irrepresentável. Neste caso, diante de um evento demasiadamente monstruoso, qualquer tentativa de retratá-lo seria insuficiente, e, portanto, falsa, uma vez que acabaria transmitindo a impressão equivocada de que aquele acontecimento teria sido "menos grave" do que realmente foi. Pior do que isso, os “artifícios” inerentes à representação poderiam provocar afetos, como o prazer, certamente incompatíveis com a gravidade e a dimensão da experiência que se pretende transmitir. Nesta discussão, o evento irrepresentável por excelência, aquele que desafia qualquer possibilidade de entendimento ou elaboração ultrapassando, assim, os “limites da representação”, é o Holocausto. Há algo de paradoxal na discussão sobre as possibilidades de se representar o genocídio promovido pelo regime nazista durante a Segunda Guerra Mundial, uma vez que a célebre tese da sua irrepresentabilidade é acompanhada de um número incalculável de representações em forma de livros de história, 
livros de ficção, livros de memórias, filmes, documentários, obras de arte, monumentos, campanhas educacionais e até mesmo museus concebidos para preservar a memória da Shoa. A respeito do tema, Max Liljefors chama atenção para a forma como nos países ocidentais o genocídio "se tornou algo que todos os cidadãos, desde professores universitários até crianças da escola primária, deveriam estudar e, sobretudo, a partir dele tirar lições” (Michelsen e Schollhammer, 2011, p. 14).

Por algum tempo parece ter vigorado o entendimento de que a arte e a literatura (como ficção) não seriam formas adequadas de se lidar com os horrores reais vivenciados nos campos de extermínio nazistas. Entre os historiadores, evidenciou-se a tendência de tentar manter as suas pesquisas dentro dos limites de um realismo "puro”, rejeitando as formas artísticas, cuja carga criativa poderia abrir uma brecha para visões relativistas, como a que questiona a própria ocorrência do Holocausto. Assim, para se lidar com a Shoa seria necessário lançar mão de meios estritamente históricos e documentais. Sobre o assunto, Mieke Bal afirma que no campo dos Estudos do Holocausto (nos quais Theodor Adorno figurou como uma das vozes mais influentes) a documentação foi extensamente defendida como a única forma "adequada” de lidar com o tema (Reindhart, Edwards, Duganne, 2007, p. 107). Sabe-se que hoje é difícil sustentar a diferença entre os livros de "História” e os livros de "histórias” e que o “documento" não deixa de possuir uma estética própria e de se munir de artifícios formais, às vezes, tão ou mais complexos do que aqueles de que lançam mão as linguagens ditas ‘artísticas”. A própria ausência de artifícios, aliás, pode ser em si um grande artifício, como comprova a produção que adota estilos sabidamente “antiartísticos” ou deliberadamente amadores. Recentemente, uma posição contrária se tornou proeminente e assumiu duas formas distintas. Primeiro, entende-se que o realismo fiel acabaria produzindo um efeito de irrealidade, uma sensação de que aquilo seria considerado absurdo demais para ser verdadeiro, e que o choque provocado (um trauma secundário) acabaria impedindo a reflexão sobre o tema. Alternativamente, entende-se que os documentos estariam fornecendo "provas" de uma realidade que não precisaria de ser provada, pois deveria ser de conhecimento geral. 
A polêmica em torno da exposição Mémoirs des Camps, montada em 2001 em Paris, é um exemplo dessa discussão. Por ocasião da exposição, um de seus organizadores, o historiador da arte francês Georges Didi-Huberman, escreveu um texto sobre as quatro fotografias tiradas clandestinamente de uma câmara de gás de Auschwitz - apesar da interdição absoluta de fotografar os campos e do controle estrito exercido pelos SS - por membros do Sonderkommando, o comando "especial” de presos que deveriam executar com as próprias mãos os procedimentos do extermínio em massa (figura 31). As fotografias, caracterizadas por ele como testemunhos visuais mostravam mulheres nuas sendo levadas para a câmara de gás e uma fogueira ao ar livre onde se queimavam os cadáveres que os crematórios, lotados, já não podiam mais comportar. Segue um trecho do texto publicado no catálogo da exposição:

"Para saber é preciso imaginar-se. Devemos tentar imaginar o que foi o inferno de Auschwitz no verão de 1944. Não invoquemos o inimaginável. Não nos protejamos dizendo que de qualquer forma não o podemos imaginar - o que é verdade - , já que não poderemos imaginá-lo inteiramente. [...] Era tão mais difícil, para os prisioneiros, arrancar aos campos de concentração esses escassos pedaços de que somos agora depositários, com o peso de o sustermos apenas com um olhar. Estes pedaços são-nos mais preciosos e menos apaziguadores do que todas as obras de arte possíveis porque foram arrancados a um mundo que os tinha por impossíveis. Imagens apesar de tudo, portanto: apesar do inferno de Auschwitz, apesar dos riscos corridos. Em retribuição, devemos contemplá-las, assumi-las, tentar dar conta delas." (Didi-Huberman, 2012, p. 15)

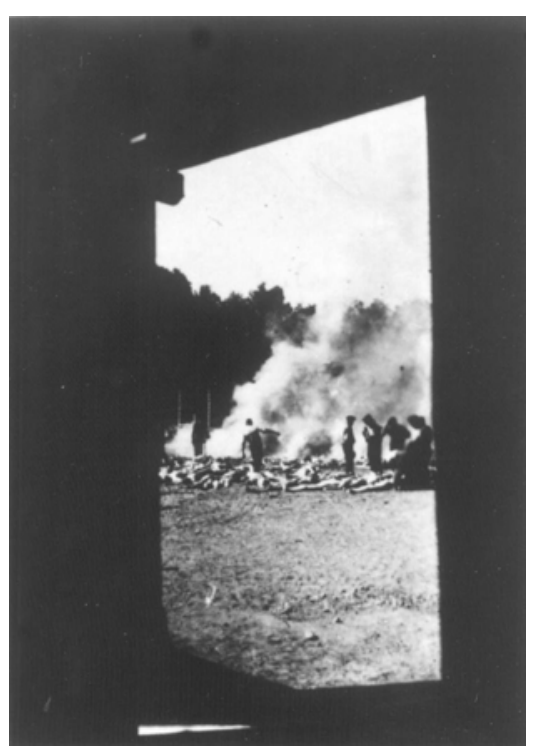

Figura 31 . Anônimo (membro do sonderkommando de Auschwitz), 1944. 
Didi-Huberman afirma que este "corpus errático de imagens apesar de tudo” refuta a ideia de inimaginável - “já não é possível falar de Auschwitz nos termos absolutos - geralmente bem intencionados, aparentemente filosóficos, na realidade preguiçosos - do 'indizível' e do 'inimaginável' (Didi-Huberman, 2012, p. 41). Relegar o genocídio perpetrado pelos nazistas à noção de “impensável” seria, pois, uma forma de se esquivar do problema. O genocídio tanto é “pensável” que foi “pensado” e dizê-lo não seria banalizar o horror, mas levar a sério esta experiência, encará-la como uma possibilidade, por mais terrível que seja. O texto de Didi-Huberman sublinha o peso de realidade que carregam estes restos de imagens, arrancadas de Auschwitz como um ato de resistência política contra a máquina de extermínio e contra a lógica nazista que apostava na "possibilidade de tornar os judeus invisíveis" e de "tornar invisível a sua própria destruição” (Didi-Huberman, 2012, p. 38). A exibição das fotografias e, principalmente, o texto de Didi-Huberman, suscitaram um debate polêmico iniciado por dois artigos publicados em maio de 2001 na revista Les Temps Modernes, por Gérard Wajcman e Élisabeth Pagnoux, respectivamente. No texto intitulado De la croyance photographique (2001) Wajcman defende a noção questionada por Didi-Huberman da irrepresentabilidade do Holocausto - “Não há imagens da Shoah”. Segundo o autor, não há imagens da Shoah, primeiro, porque não há qualquer imagem mostrando o momento do extermínio de judeus na câmara de gás; segundo, por uma impotência da própria imagem em transmitir o real - “todo o real não é solúvel no visível” (Wajcman, 2001, p. 47); e por fim, porque há algo de irrepresentável na Shoa, algo que não pode ser fixado por nenhuma imagem. Seria muito difícil refutar este argumento se o seu objetivo fosse apenas contestar a noção de que as quatro fotografias tivessem o poder de apresentar o processo de extermínio em sua totalidade. Contudo, as fotos, nas circunstâncias em que foram tiradas, evidentemente não poderiam se propor a dar conta da totalidade de um evento infinitamente amplo, complexo, transbordante quanto foi o extermínio dos judeus na Europa. Tampouco é esta a reivindicação feita por Didi-Huberman em seu texto, que não deixa de enfatizar a natureza essencialmente lacunar das imagens, esses “instantes de verdade”, como ele diz. Uma imagem será sempre parcial, um fragmento - um número restrito de cadáveres enquadrado pela visão de um membro do Sonderkommando apenas “É claro que as quatro fotografias de agosto de 1944 não dizem 'toda a verdade' 
(é preciso ser muito ingênuo para esperar isso do que quer que seja, coisas, palavras, ou imagens): são minúsculas amostras de uma realidade complexa, breves instantes de um contínuo que durou não menos do que cinco anos” (DidiHuberman, 2012, p. 58). Em 2009, em um dos capítulos de seu livro $O$ Espectador Emancipado, Rancière se debruça sobre esta polêmica e a sua análise nos interessa imensamente, pois o autor identifica no cerne do debate a oposição entre palavra e imagem. Rancière afirma que o argumento levantado por Wajcman sobre a impossibilidade das quatro imagens representarem a Shoah busca estabelecer uma oposição radical entre duas formas de representação - a imagem visível e a narrativa verbal - e duas formas de “atestado" - a prova e o testemunho (Rancière, 2009-A, p. 89). Condena-se as quatro fotografias, e o texto escrito sobre elas, porque a pessoa que as tirou e aquele que as comenta concebem-nas como "provas" de uma realidade que prescinde, ou que ao menos deveria prescindir delas. "Eles são criticados por terem acreditado que a realidade do processo precisava ser provada e que a imagem visível fornecia tal prova" (Rancière, 2009, p. 90). Os opositores da exposição dirão que a Shoa ocorreu, que este é um fato que não precisa de provas, pois é conhecido por todos e que este conhecimento é baseado no testemunho. É possível perceber, portanto, que o que se postula não é a legitimidade de determinadas imagens (imagens estetizadas, imagens parciais, imagens explícitas), mas algo muito mais abrangente, a legitimidade da imagem em si, de uma forma geral, qualquer imagem, como um veículo adequado, ou mesmo legítimo, para representar o desastre.

Essa questão leva-nos de volta ao ponto de partida da presente pesquisa, a saber, até que ponto é possível traçar uma linha divisória entre a palavra e a imagem. Até que ponto a imagem (prova) realmente se difere da palavra (testemunho)? Já sublinhamos a relação necessária entre a palavra e a imagem, a maneira como a palavra (falada ou escrita) tem o poder de despertar imagens mentais, ao passo que as imagens são capazes de evocar palavras, sentidos, discursos, narrativas. O visível e o dizível são domínios complementares, faces da mesma moeda. Aquele que "testemunha” esforça-se para dar a ver o que foi visto por ele, para articular em palavras uma vivência que nunca poderá ser inteiramente recuperada, nem por sua fala e nem por nenhuma imagem. $\mathrm{O}$ testemunho passa por um processo de construção de imagens, entendidas em seu sentido mais amplo, não como cópias visíveis de uma realidade, mas como um 
complexo de relações entre "o visível e o invisível, o visível e o discurso, o dito e o não dito” (Rancière, 2009-A, p. 93). Não se trata, portanto, de uma manifestação direta de algo invisível, mas de um trabalho de representação, que opera deslocamentos, que elege um ponto de vista parcial e que enfatiza lacunas e ausências tanto quanto o faz a imagem capturada pela câmera fotográfica. A representação verbal, ou o testemunho, não é mais verdadeira do que são as representações visuais. Com efeito, qualquer representação, visual ou linguística, profissional ou amadora, “estetizada” ou não, em primeira ou em terceira pessoa, é sempre uma (re)construção que resulta em algo outro, distinto do dado empírico ou do referente primeiro. Um testemunho, por mais objetivo que se pretenda, submete-se a uma separação temporal que abre espaço para a intervenção do caráter seletivo da memória, que filtra, hierarquiza e remodela as experiências do passado em função de experiências posteriores. Um relato de uma experiência pessoal pregressa passa sempre por uma auto-interpretação sujeita não apenas à relação que o narrador/a testemunha mantém com seu próprio passado, mas também à forma como pretende dar este passado a conhecer ao outro, e à incapacidade da linguagem de transpor sem fraturas ou distorções a experiência para o discurso.

As imagens passam a ser inapropriadas se lhes é atribuída a tarefa de mostrar tudo o que acontecia nos campos, se lhes for negada a natureza lacunar, a prerrogativa de mostrar também ausências. Da mesma forma, as palavras se mostrarão inadequadas sempre que se esperar delas que contem "toda a verdade”, que possam abarcar o fato inteiro, pois, sabe-se, haverá sempre muito que lhes escapará. E esse mérito atribuído à palavra, o de não dizer tudo, enfatizando, com o que se diz, o que não é dito encontra paralelo na imagem, que não pode nunca mostrar tudo, mas que estabelece ressonâncias e correspondências com outras fontes, não apenas visuais, mas também verbais. Neste sentido, um testemunho é constituído pelo que é dito, pelo que se torna visível, e também por seus silêncios, da mesma forma que uma imagem é constituída pelo que é mostrado, pelo que se torna dizível e por suas lacunas, criadoras de visualidades que se estendem para além dos limites da visão.

Na polêmica em torno de Mémoirs des Camps, um filme de Claude Lanzmann, Shoah (1985), é citado como um dos pilares que sustentam o discurso do irrepresentável que circula em torno do Holocausto. Contra o que se entende 
como uma espetacularização do genocídio através da difusão massiva de signos visuais relacionados ao extermínio, o filme opta por não utilizar imagens de arquivo, baseando-se inteiramente nos testemunhos de sobreviventes. Numa das sequências, um dos sobreviventes, o barbeiro Abraham Bomba, é solicitado a contar a sua experiência como membro do Sonderkommando, forçado a cortar o cabelo de mulheres prestes a entrar na câmara de gás. Em um determinado momento, apesar dos incentivos de seu interlocutor (Lanzmann), Bomba interrompe o seu testemunho - "é muito horrível”, diz, com a voz embargada. Este silêncio, esta impossibilidade de falar, é interpretada, no contexto desta discussão, como uma demonstração do caráter irrepresentável da experiência vivida por Bomba. Mas, como será enfatizado por Rancière, esta impossibilidade só passa a existir por intermédio de uma imagem. Bomba não pode encontrar palavras adequadas para expressar a dimensão do horror rememorado, mas essa impossibilidade não é expressa senão pelas imagens - são as imagens comoventes de seu silêncio, da sua expressão facial, das suas lágrimas que evocam o discurso em torno da noção do irrepresentável. "Shoah não dá a ver aquilo que as testemunhas viveram aquando do processo de extermínio; mas mostra os próprios sobreviventes entregues à provação trágica da reminiscência” (Didi-Huberman, 2012, p. 172). A insistência de Lanzmann para que Bomba continue a sua história culmina com a cena consternadora de sua impossibilidade, cena que acaba representando para o espectador do documentário, através de detalhes sutis registrados pelas imagens, a própria ideia de irrepresentabilidade do horror testemunhado que o interlocutor de Bomba busca afirmar.

\section{5}

\section{Dos Regimes da Arte}

A partir da polêmica em torno da exposição Mémoirs des Camps, é possível perceber a formação de um contexto intelectual que confere um grande prestígio à narrativa testemunhal, em detrimento da representação visual, que é posta sob suspeita e questionada enquanto veículo legítimo de representação do desastre e do sofrimento. É válido tentar entender quais seriam os pressupostos e as implicações desta tentativa de se estabelecer uma hierarquia entre as linguagens 
e, para tanto, a teoria dos regimes da arte, formulada por Rancière, pode se mostrar um terreno fértil para pensar esta conjuntura. Rancière fala em três grandes regimes de identificação da arte na tradição ocidental, isto é, em três tipos específicos de "ligação entre modos de produção das obras ou das práticas, formas de visibilidade dessas práticas e modos de conceituação destas ou daquelas” (Rancière, 2009-B, p. 27). O primeiro regime, chamado de Regime Ético, não envolvia a noção de "arte" como ela é pensada atualmente - "neste regime a arte não é identificada enquanto tal, mas encontra-se subsumida na questão das imagens” (Rancière, 2009-B, p. 28). O que se analisava eram apenas “imagens” e o que era posto em questão era, primeiro, a relação destas imagens com a sua origem (o seu teor de verdade) e, segundo, os efeitos que elas seriam capazes de induzir nos espectadores. Nesta relação entre a verdade e a imagem está a base da polêmica platônica em torno dos simulacros da pintura, do poema e da cena. Neste debate, o poeta é visto como um criador de imagens, cópias da verdade, ou simulacros, que teriam o poder de nos afastar ainda mais da verdade.

No segundo regime, o Representativo, as artes são identificadas pelo par poesis/mímesis. Por mímeses, não se entende a cópia fiel ao modelo, mas uma normatividade que regula o regime dos gêneros, estabelecendo critérios hierárquicos de comparação e distinção entre as artes. No regime representativo a questão da autenticidade (da relação entre cópia e modelo) é deixada de lado e, com ela, a separação entre a ficção e o fato empírico. As artes não mimetizam o mundo sensível, mas representam mundos possíveis. Assim, na literatura, por exemplo, o critério de verdade é substituído pelo critério de verossimilhança. "É o feito do poema, a fabricação de uma intriga que orquestra ações representando homens agindo, que importa, em detrimento do ser da imagem, cópia interrogada sobre seu modelo” (Rancière, 2009-B, p. 30). Neste contexto, há uma afirmação da ação sobre a passividade, da narração sobre a descrição. É neste regime que se pode falar na possibilidade ou na impossibilidade de representação de determinados temas ou objetos por um modo de fazer específico. Neste sentido, os heróis, como temas nobres, seriam dignos de serem representados pela tragédia ou pela epopeia, ao passo que ao homem comum caberiam os espaços “menores” da comédia e da sátira.

Ao Regime Representativo contrapõe-se o Regime Estético, no qual a identificação da arte é feita pela identificação de um modo de ser sensível aos 
produtos da arte. Rancière afirma que este movimento se inicia com o Realismo do século XIX, que ele entende não como a busca da semelhança, mas justamente como a subversão dos limites dentro dos quais a semelhança era contida. Com a ausência de limites intrínsecos à representação, não faria mais sentido falar em temas inapropriados para a arte - "como Flaubert colocou, 'Yvetot equivale à Constantinopla' e os adultérios da filha de um camponês equivalem aos de Teseu, Édipo ou Climenestra” (Rancière, 2007, p. 118). A revogação da tradicional hierarquia entre os gêneros literários ou pictóricos, promove o nivelamento de temas “altos” e "baixos” e possibilita que importantes acontecimentos históricos figurem nas representações lado a lado com episódios cotidianos e detalhes minuciosos. Assim, a deusa grega e a cortesã, o casal de monarcas e o casal de trabalhadores agrários, o casamento e a siesta passam a ser igualmente “representáveis”, por qualquer modo ou linguagem, visto que não há mais regras que determinem a correspondência entre um conteúdo específico e uma forma adequada. Na literatura realista, assiste-se a uma suspenção do primado do narrativo sobre o descritivo, da hierarquia entre a atividade do pensamento (narração) e a passividade sensível (descrição). Assim, a descrição detalhada de pequenas percepções pode ser privilegiada em detrimento da narração das ações que impulsionam uma sucessão de eventos. Na pintura, vemos a reabilitação por Hegel das chamadas cenas de gênero características da tradição pictórica flamenga do século XVII - representações da vida cotidiana, do mundo do trabalho e da intimidade doméstica que privilegiam a descrição minuciosa e precisa do mundo visível em detrimento da representação de ações humanas significativas para a expressão da história. A aparente banalidade dos temas tratados na pintura flamenga era contrastada à magnitude dos grandes eventos narrados na pintura religiosa ou histórica. Nessas cenas, destaca-se a descrição detalhada e minuciosa de tudo o que há na natureza, de forma exata e não seletiva, inclusive de objetos considerados “menores”, “insignificantes” ou “acessórios”. Neste sentido, Hegel, conhecido entusiasta da arte holandesa, observa: "é nesta mesma animação despreocupada que reside o momento ideal: é o domingo da vida que tudo nivela e afasta toda a maldade; seres humanos que estão cordialmente de bom humor não podem ser completamente ruins e abjetos" (Hegel, 2002, p. 275). Segundo Hegel, a “alegria”, a “jovialidade” e a “desenvoltura” presentes na pintura flamenga do século XVII seriam uma espécie 
de celebração da conquista vitoriosa de sua autonomia religiosa e civil depois de um século conflituoso. Ao desobrigar a arte do sistema de regras a que os temas e os gêneros eram submetidos, o Regime Estético implode, ainda, as barreiras que separavam a arte de outros fazeres - "ele afirma a absoluta singularidade da arte e destrói ao mesmo tempo todo critério pragmático dessa singularidade. Funda, a uma só vez, a autonomia da arte e a identidade de suas formas com as formas pelas quais a vida se forma a si mesma” (Rancière, 2009-B, p. 34). Assim, a arte só é percebida na medida em que é arte e não arte ao mesmo tempo.

Uma reflexão sobre o que torna aceitável ou não uma representação do desastre, ou do sofrimento do outro, mostra-se um terreno fértil para pensarmos o contexto atual em termos de uma constelação entre os três regimes da arte definidos por Rancière. Embora, hoje, as características do Regime Estético sejam predominantes, é possível notar traços tanto do Regime Ético quanto do regime representativo nas discussões sobre a arte. Quando as quatro fotografias tiradas pelos membros do Sonderkommando são condenadas sob os argumentos de que seriam falsas, mentirosas, insuficientes e incapazes de fazer jus à dimensão do evento, vemos comparecer novamente os critérios platônicos, que julgavam a relação de uma imagem com a sua origem, ou seja, o seu teor de verdade. Quando imputa-se às imagens a obrigação de mostrar $a$ verdade, ou quando as condenam sob o argumento de que elas mentem, de que são falsos semelhantes, estamos no terreno do Regime Ético da arte. O mesmo pode-se dizer em relação à discussão sobre os efeitos das fotografias. A ansiedade em relação à sua capacidade de causar indiferença, efeitos de irrealidade ou mesmo prazer - "voyeurismo" ou "horror do gozo", nas palavras de Élisabeth Pagnoux, também evoca o platonismo, na medida em que evidencia uma preocupação em relação ao destino da imagem, ou seja, aos usos que lhe são atribuídos e aos efeitos que elas são capazes de induzir.

Por outro lado, quando Pagnoux se diz “escandalizada” e lança, perplexa, a pergunta, “Auschwitz, um objeto fotogênico?”, vemos resgatado o pensamento que legisla sobre as regras de adequação entre forma e conteúdo. Essa normatividade, da qual o regime estético teria livrado a arte há mais de um século, restabelece a antiga hierarquia entre as formas, característica do Regime Representativo. Ao que parece, não há eventos em essência irrepresentáveis, há uma tentativa de se estabelecer maneiras adequadas e inadequadas de abordar 
certos assuntos. O debate acerca da impossibilidade de se representar determinados eventos acaba se traduzindo em uma discussão acerca da forma ou do meio mais adequado para representá-los e um privilégio da representação linguística em detrimento da representação visual evidencia-se de maneira inconteste. As formas, e não mais os conteúdos, são postos novamente sob a ótica da dignidade e nessa discussão, para representar o tema da Shoah, por exemplo, a imagem é considerada uma forma indigna. Neste caso, ouvimos o eco da voz de Lessing que, no século XVIII, defendeu a teoria de que nem todos os meios artísticos seriam apropriados para representar um determinado tema ou objeto. É valido pararmos e nos questionarmos, portanto, se não estaríamos indo "rumo (novamente) a um mais novo Laocoonte”.

Representar a dor do outro não é, certamente, tarefa simples e uma boa dose de cuidado é necessária para que o movimento de dar visibilidade a uma questão que necessita de atenção não se transforme em uma segunda forma de apropriação, exposição e violação da subjetividade daqueles que se tornam objetos da representação. Expressar e perceber a dor de alguém exige um esforço ético e intelectual, uma capacidade de imaginação e reflexão, não apenas por parte de quem representa como também por parte do espectador a quem se dirige a representação. Mas estas exigências se apresentam tanto para as representações visuais quanto para as verbais e não serão "leis” definidas a priori que garantirão a integridade deste movimento. A decisão de abordar tais temas coloca o artista numa posição delicada, pois, como foi mencionado, a linha que separa a apresentação de um sofrimento com fins de intervir na realidade que o comporta e a exploração de um sofrimento com fins comerciais é tênue e instável. Entendemos que a dor é uma experiência singular e privada e que o sujeito que sofre possa se sentir isolado pela suposta incomunicabilidade de sua experiência. Mas entendemos também que talvez seja necessário buscar formas de tentar ultrapassar as barreiras que definem essas experiências como incomunicáveis, encontrando um equilíbrio entre o completo isolamento e a exploração inescrupulosa, entre a ignorância (ou a negação) e a exposição pornográfica. O uso da violência sexual como uma arma e uma estratégia político-militar, levada a cabo sistematicamente por soldados em regiões transformadas por conflitos civis e políticos não é desconhecido, mas talvez seja pouco discutido. É importante que situações como a ocorrida na Bósnia na década de 90, na Síria atualmente e tantas 
outras que transcorrem relativamente isentas de documentação sejam não apenas conhecidas, mas que se reflita sobre elas de uma perspectiva distinta, ampliandose o foco usual que enquadra apenas a vítima e o seu sofrimento. Neste sentido, no centro da "orquestra” de vozes articulada em Lustmord não está a mulher, e sim a própria experiência do estupro e a relação que se estabelece entre esses três sujeitos, apresentados não como objeto da fala de um terceiro, mas como sujeitos de um discurso próprio, ainda que fictício. A figura do "observador" ou da “testemunha” que divide o espaço da obra com o "perpetrador” e a "vítima” ressalta que o outro, objeto do olhar, é também alguém que olha. E além das três posições criadas por Holzer, o trabalho inclui uma quarta, a do observador “privilegiado", leitor da revista, que é forçado a tomar consciência do seu processo de observação quando a distância que o separa da vítima é suprimida.

O choque, a indignação, o nojo ou mesmo o sentimento de solidariedade provocado por uma cena ultrajante, apesar de concederem ao espectador um atestado de humanidade, não são sequer muito eficazes para ajudá-lo a compreender o que ocorreu e, menos ainda, para fazê-lo refletir sobre a forma como seus privilégios podem situar-se no mesmo mapa daqueles sofrimentos. A solidariedade proclama a sensibilidade do espectador, mas, muitas vezes, proclama também, de forma gratificante, justamente a sua inocência. O espectador que assiste mortificado à dor do outro, se julga incapaz de fazer qualquer coisa semelhante e, portanto, distante e alheio àqueles eventos. Neste sentido, são bem vindos os trabalhos que escapam do foco exclusivo nos (já exauridos) efeitos de choque, que buscam os (igualmente exauridos) afetos de indignação. Lustmord parece afirmar que olhar apenas não é suficiente, é necessário também dar-se conta de que se está olhando. Neste sentido, o espectador é convidado não apenas a refletir sobre a realidade afirmada pelo trabalho, mas também sobre o que significa ser espectador desta realidade. Seu mérito, portanto, não está tanto na sua capacidade de conscientizar os leitores da Süddeutsche Zeitung Magazin sobre as atrocidades cometidas na Bósnia e nem de causar a sua indignação, embora isso deva ocorrer também. Trata-se de estabelecer novas maneiras de afirmar uma realidade que, em maior ou menor grau, já era conhecida e, sobretudo, de estabelecer "novas configurações do que pode ser visto, do que pode ser dito e do que pode ser pensado e, consequentemente, uma nova paisagem do possível” (Rancière, 2009-A, 103). O trabalho de Holzer certamente explora o poder da 
linguagem, mas de uma maneira complexa, multivalente, na qual os domínios do conteúdo e da forma, dos significados e dos afetos, do inteligível e do sensível se amplificam e se confundem. Coloca-se ao lado das iniciativas que se recusam a conceber a arte como um objeto distante, intocável, aquém ou além da política e das questões sociais, econômicas e culturais que atravessam o cotidiano dos indivíduos. Afirma que a arte deve ser "tocada”, discutida, elaborada, provocar afetos e efeitos sensuais ao mesmo tempo em que gera reflexão e não para de propor questões e, neste sentido, coincide com o que Mieke Bal chamou de uma filosofia visual, imagens que “levantam questões sem, no entanto, respondê-las" (Reindhart, Edwards, Duganne, 2007, p. 114).

Holzer articula os seus textos tendo como referência não apenas a obra de outros escritores, mas também, e principalmente, as obras de outros artistas visuais, como Goya, Rothko e Matisse. Como resultado, seu trabalho absorve qualidades estéticas de formas de expressão distintas, transitando não apenas entre o texto e a imagem, mas entre diferentes territórios como a pintura, a escultura, o cinema, a literatura, a propaganda e a performance. A sua obra une poderes e peculiaridades de diversos meios e modos de representação, compondo combinações únicas. Neste sentido, dialoga novamente com um conceito usado por Rancière para abordar as condições representativas da contemporaneidade. O filósofo francês fala de uma "imagem pensativa" para se referir a uma imagem que se constitui a partir de modos distintos de representação e que, por isso, contém a presença latente de outros regimes de expressão. Neste sentido, as novas tecnologias das quais Holzer lança mão sem se preocupar com um suposto sentido ontológico da arte se destacam ao oferecer formas inéditas de mesclar os efeitos de diferentes artes, meios e linguagens, possibilitando o encontro e o confronto de elementos heterogêneos e despertando novas possibilidades sensíveis. 


\section{Referências bibliográficas}

ABEL, E. Redefining de Sister Arts. In: Mitchell, W. J. T. (org.) The Language of Images. Chicago: The University o Chicago Press, 1980.

AgAmben, G. The Man Without Content. California: Stanford University Press, 1999.

ALBERTI, L. B. Da Pintura. Tradução de Antonio Silveira Mendonça. Campinas: Ed. Unicamp, 2009.

ALPERS, S. The Art of Describing: Dutch Art in the Seventeenth Century. Chicago: University of Chicago Press, 1983.

AUGÉ, M. Não-Lugares: Introdução a uma antropologia da supermodernidade. $4^{\mathrm{a}}$ Edição. Tradução Maria Lúcia Pereira. Campinas, SP: Papirus, 2004.

BAUDELAIRE, C. Sobre a Modernidade. Organizador Teixeira Coelho. Rio de Janeiro: Paz e Terra, 1996.

- The Life and Work of Eugène Delacroix. In: MAYNE, Jonathan. (org. e trad.) The Painter of Modern Life and Other Essays. London: Phaidon Press, 2006.

BECKETT, S. Molloy. Rio de Janeiro: Nova Fronteira, 1988.

Benjamin, W. Magia e Técnica, Arte e Política. Obras Escolhidas, Vol. 1. São Paulo: Editora Brasiliense, 1996.

BAL, M. Reading Rembrandt: Beyond the Word-Image Opposition. Amsterdam: Amsterdam University Press, 2006.

BARTHES, R. O Rumor da Língua. Martins Fontes: São Paulo. 2004

A Câmara Clara. Rio de Janeiro: Nova Fronteira, 1984.

BRYSON, N.; HOLLY, M. e MOXEY, K. Visual Culture: Images and Interpretations. Middle Town: Wesleyan University Press, 1994.

CAMPOS, H. (organizador). Ideograma, lógica poesia linguagem. São Paulo: Editora Cultrix, 1986.

CAMPOS, A., PIGNATARI, D. e CAMPOS, H. Teoria da Poesia Concreta. SP: Ateliê Editorial, 2006.

DANTO, A. C. The Abuse of Beauty. Chicago: Open Court, 2006 
DELEUZE, G. A Imagem-Tempo. Tradução Eloisa de Araujo Ribeiro. São Paulo: Brasiliense, 2007.

DIDI-HUBERMAN, G. Imagens Apesar de Tudo. trad. V. Brito e J. P. Lisboa: Ymago, 2012.

DOHERTY, C. Situation: documents of contemporary art. Londres: Whitechapel Gallery, 2009.

FERREIRA, G. e COTRIM, C. (organizadores.). Clement Greenberg e o debate crítico. Tradução de Maria Luisa X. de A. Borges. Rio de Janeiro: Jorge Zahar, 2001.

FOSTER, H. The Return of the Real. Cambridge: The MIT Press. 1996.

Seattle: Bay Press, 1986.

KRAUSS, Rosalind, BOIS, Yve-Alain, BUCHLOH, Benjamin h. d. Art Since 1900. Thames and Hudson: New York, 2007.

FOUCAULT, M. Isto Não é um Cachimbo. Tradução Jorge Coli. $5^{a}$ Edição. Rio de Janeiro: Paz e Terra, 2008.

As Palavras e as Coisas. Tradução Salma Tannus Muchail. São Paulo: Martins Fontes, 2007.

GOMBRICH, E.H. Arte e Ilusão. Tradução Raul de Sá Barbosa. São Paulo: Martins Fontes, 1986.

HEGEL, G.W.F. Curso de Estética, Volume III (Tradução de Marco Aurélio Werle e Oliver Tolle). São Paulo: Ed. Edusp, 2002.

HOWELLS, R. e NEGREIROS, J. Visual Culture. $2^{\text {a }}$ Edição. Cambridge: Polity Press, 2012.

HUGHES, G. Power's Script: or, Jenny Holzer's Art after 'Art after Pilosophy'. Oxford Art Journal, Vol. 29, Issue 3, p. 419-440.

HUGHES, R. Goya. Tradução Tuca Magalhães. São Paulo: Companhia das Letras, 2007.

JOSELIT, D., SIMON, J. e SALECL, R. Jenny Holzer. London: Phaidon Press, 1998.

KARPELES, E. Paintings in Proust. London: Thames \& Hudson, 2008.

KOTZ, L. Words to Be Looked At: Language in 1960s Art. Cambridge: The MIT Press, 2010.

LESSING, G.E. Laocoonte. In: De Teatro e Literatura. São Paulo: Editora Herder, 1964. 
Laocoonte, ou sobre as fronteiras da Pintura e da Poesia. Introdução tradução e notas Márcio Seligmann-Silva. São Paulo: Iluminuras, 1998.

LUKÁCS, G. Ensaios sobre Literatura. Rio de Janeiro: Civilização Brasileira, 1965.

LYOTARD, F. A Condição Pós-Moderna. Tradução Ricardo Corrêa Barbosa. $12^{\mathrm{a}}$ Edição. Rio de Janeiro: José Olympio Editora, 2009.

MERLEAU-PONTY, M. A Fenomenologia da Percepção. Tradução Carlos Alberto Ribeiro de Moura. São Paulo: Martins Fontes, 1999.

MICHELSEN, A. SCHOLLHAMMER, K.E. Atrocity Exhibition. Denmark: IKK, 2001.

MILLER, J.H. Illustration. Cambridge: Harvard University Press, 1992.

MITCHELL, W.J.T. (org.) The Language of Images. Chicago: The University of Chicago Press, 1980.

Chicago Press, 1987.

Iconology: Image, Text, Ideology. Chicago: The University of Picture Theory. Chicago: The University of Chicago Press, 1995.

. There are no Visual Media. 2005 http://www.mediaarthistory.org/refresh/Programmatic\%20key\%20texts/pdfs/mitc hell.pdf

PAZ, O. Signos em Rotação. São Paulo: Perspectiva, 2006.

PEIXOTO, N. Paisagens Urbanas. $4^{\text {a }}$ Edição. São Paulo: Editora Senac, 2003.

RANCIÈRE, J. A Partilha do Sensível. Tradução Mônica Costa Neto. $2^{\text {a }}$ Edição. São Paulo: editora 34, 2009 - B.

London: Verso, 2009 - B.

Verso, 2007.

REINHARDT, M.; EDWARDS H. and DUGANNE, E. Beautiful Suffering: Photography and Traffic in Pain. Chicago: University of Chicago Press, 2007.

RORTY, R. A Filosofia e o espelho da natureza. Tradução Antônio Trânsito. Rio de Janeiro: Relume Dumará, 1995.

SAUSSURE, F. Curso de Linguística Geral. Organizadores: Charles Bally e Albert Sechehaye. São Paulo: Editora Cultrix, 2006. 
SCHOLLHAMMER, K.E. Além do Visível, o olhar da literatura. Rio de Janeiro: 7 Letras, 2007.

PUC-Rio, 2002.

SONTAG, S. Diante da Dor dos Outros. Tradução Rubens Figueiredo. São Paulo: Companhia das Letras, 2003)

WALDMAN, D. Jenny Holzer. 2 ${ }^{a}$ Edição. New York: Guggeinheim Museum, 1997.

WOLF, T. The Painted Word. New York: Farrar, Strauss and Giroux, 1975. 